\title{
Russian Emigrants and Polish Underground in 1939-1948
}

Zarys treści: Udział emigrantów rosyjskich w II wojnie światowej jest znany, choć najczęściej kojarzony ze współpracą i zaangażowaniem po stronie państw Osi. Jednak wśród porewolucyjnej diaspory rosyjskiej w Polsce znaleźli się ludzie, którzy zdecydowali się walczyć w szeregach polskiego podziemia w ramach Wielkiej Koalicji, przeciwstawiającej Niemcom i ich sojusznikom w latach 1939-1945. Wygnańcy rosyjscy byli zaangażowani w konspirację rożnych orientacji - od komunistycznej do narodowej.

Outline of contents: The contribution of Russian emigrants to World War II is widely known, but most often it brings to mind their cooperation and engagement on the Axis side. However, there were several individuals among the post-revolution Russian diaspora in Poland, who decided to fight the Germans and their allies as part of the Polish resistance movement and the Grand Coalition 1939-45. Russian exiles were involved in conspiratorial endeavours of various orientations, from communist to nationalist ones.

Słowa kluczowe: II wojna światowa, Polska w czasie II wojny światowej, biała emigracja rosyjska w Polsce, Polskie Państwo Podziemne, konspiracja w Polsce w czasie II wojny światowej, rosyjscy emigranci w polskim podziemiu

Keywords: World War II, Poland during WWII, White Russian emigration in Poland, Polish Underground State, resistance movement in Poland during WWII, Russian émigrés in the Polish resistance movement

In 1931, the Second Polish Republic was home to 138,700 speakers of Russian, who constituted $0.43 \%$ of Polish citizens; the largest community lived in Wilno/Vilno (7,372 people, out of which 5,276 were Orthodox), which means they outnumbered the Lithuanians. The capital of Poland had 4 thousand permanent Russian 
residents (and 9,100 residents were Orthodox), which made them the third-most numerous ethnic group, after Poles and Jews. ${ }^{1}$

With regard to the Russian community in Wilno/Vilno in the early 1920s, an anonymous Polish governmental analyst stated as follows: "It consists mostly of pre-war affluent citizens, who now, because of [...] post-war relations, are forced to confine themselves to a minimum. For this reason, they remain in opposition to the Polish government, and, as their most fond memories are associated with the Russia of yesteryear, the majority of them are monarchists". ${ }^{2}$ It is important to remember the attitude of Poles towards "Russianness", "Russians" and "Russia" which could be interpreted abstractly as "Polish Russophobia" - shaped under the pressure of the experience of the Partitions, and rejected by truly few Polish citizens, mostly sympathisers of communism: "It was in Poland, more than anywhere else, that young people like us, or even elders, would reject - en bloc, a priori the entire knowledge of many generations about Russia. Precisely because it was based on clichés; stereotypes about a misunderstood nation". ${ }^{3}$

The attitude of Poles towards Russian nationals remained ambivalent, as summed up by Dmitri Filosofov (Polish: Dymitr Fiłosofow), who actually cooperated with Poles for ideological, rather than financial reasons. This Russian writer expressed arguably the most accurate summary of the shortcomings of Poland's ethnic and religious policies during the inter-war period: "You have two 'camps' in Poland. The first one says: there are Ukrainians, Belarusians, but no Russians. For Ukrainians and Belarusians, we are willing to do a lot. Nothing, however, is being done. The other camp asserts: there are only Russians. But nothing is being done for the Russians either. Both camps point fingers at each other, both considering the other a threat". ${ }^{4}$ As a staunch propagator of a "third" - anti-Bolshevik, anti-imperial, and democratic - Russia, he sought to improve Polish-Russian relations and to counter the symptoms of chauvinism on both sides. He always

\footnotetext{
${ }^{1}$ The Wilno Voivodeship was inhabited by 35,981 Russian-speaking citizens, out of which 9,625 were Orthodox, Drugi Powszechny Spis Ludności z dn. 9 XII 1931 r., Miasto Wilno, Statystyka Polski, Series C, vol. 48, Warszawa, 1937, p. 11; Drugi Powszechny Spis Ludności z dn. 9 XII 1931 r., Województwo Wileńskie bez miasta Wilna, Statystyka Polski, Series C, vol. 36, Warszawa, 1936, pp. 10-11; the Nowogródek Voivodeship was inhabited by 6,794 Russian speakers, out of which 6,489 were Orthodox, Drugi Powszechny Spis Ludności z dn. 9 XII 1931 r., Województwo Nowogródzkie, Statystyka Polski, Series C, vol. 71, Warszawa, 1938, pp. 10-11. Overall in Poland: 138,700 (53,300 in cities), Białystok Voivodeship 35,000 (10,500 in cities), Wilno V. 43,300 (9,700 in cities), Nowogródek V. 6,800 (2,500 in cities), Polesie V. 16,200 (7,800 in cities), Wołyń V. 23,400 (13,400 in cities), Mały rocznik statystyczny 1939, Warszawa, 1938, pp. 22 and 26.

2 Archives of Modern Records (hereinafter: AAN), Embassy of the Republic of Poland in Paris, file 82, "Zarys rosyjskiego ruchu monarchistycznego na terenie Wileńszczyzny" [Outline of the Russian monarchist movement in the Wilno Land], fol. 129.

3 A. Wat, Mój wiek. Pamiętnik mówiony, vol. 1, Warszawa, 1990, p. 140.

4 "Listy Dymitra Fiłosofowa do Mariana Zdziechowskiego", ed. P. Ławriniec, Zeszyty Historyczne, 2008, vol. 165, p. 185.
} 
called for restraint in case of ethnic conflicts within the Second Polish Republic, as these only benefited the Soviet Union.

The majority of the Polish society (including state and local officials) was bound by prejudice, also accentuated by the Russian immigrants themselves; it should also be emphasised that few Russian immigrants were actually willing to undertake cooperation with the Poles during the inter-war period, as they would be subjected to general ostracism from fellow émigrés (with notable exceptions such as Boris Savinkov [Borys Sawinkow] and Dmitri Filosofov). The Polish-Russian circulus vitiosus revolved between "distrustful unfriendliness" and "Polish Russophobia", and was "doomed to end in failure". For this reason, no significant military or intelligence cooperation has been initiated with Russian émigrés in the years 1918-1939, save for contacts with Savinkov's successive organisations, and joint activities with the Russian All-Military Union (Russki obshche-voyniski soyuz, ROVS). ${ }^{5}$

The Russian Committee (Russki komitet; RK), in cooperation with the Russian Red Cross (Russki krasny krest; RKK), met most of the needs of Russian émigrés in terms of charitable activities. The organisation also maintained the "Russian House" (Russki dom) at 68 Marszałkowska Street, shut down in 1928 after the unsuccessful assassination attempt on Alexei Lizarev (Aleksiej Lizariew) by Yuri Voytsekhovski (Jurij Wojciechowski). There were also Savinkov's Russian Evacuation Committee (Russki evakuatsyonny komitet, REK), Russian Committee for Care of Immigrants in Poland (Russki popechitelny ob emigrantakh $v$ Polshe komitet, RPK), and many other social, cultural and charitable foundations. ${ }^{6}$

Orthodox churches served as the hub of the Russian diaspora in Poland. The vast majority of Russian émigrés were associated with the Orthodox Church throughout the entire inter-war period; active participation in spiritual life was considered a key element of the "Russian identity". It is difficult to assess the intensity of the immigrants' engagement, or the actual (rather than declared) number of followers. They joined already existing structures hoping to adapt them to their views and current needs. The places of worship brought together all believers, including those who took advantage of the opportunity to infiltrate "class enemies". For instance, the Mary Magdalene Orthodox Church in Warsaw in the right-bank district of Praga was one of the key unofficial meeting centres of the White Russians. "Having chanted 'God, save the Tsar' [Bozhe, Tsarya khrani], they would walk out into the square before the temple, promptly turning it into

${ }^{5}$ However, some unconfirmed anecdotal accounts suggest that Marshal Piłsudski used to pay incognito visits to his companion in misery from katorga camps, the Russian émigré priest living in Warsaw, Aleksandr Inozemtsev; see: W. Stanisławski, "Myśl polityczna emigracji rosyjskiej w II Rzeczpospolitej: interpretacje przeszłości i koncepcje polityczne”, $\mathrm{PhD}$ diss. under supervision of Prof. dr. hab. S. Rudnicki, Institute of History, University of Warsaw, 2002, typescript of PhD diss. 358, pp. 225-228, 250-258 and 275-286.

6 A. Juzwenko, Polska a "biała" Rosja (od listopada 1918 do kwietnia 1920 r.), Wrocław, 1973, p. 108; and Stanisławski, Myśl polityczna, pp. 181-187. 
almost a fair. Many would show up not so much out of spiritual need, but rather to attend the social gatherings, to exchange opinions, to gossip, or to make some businesses, and not always clean ones".

The outbreak of the war altered the situation fundamentally, as described by Sergei Voytsekhovski (Siergiej Wojciechowski):

The fall of Poland was a catastrophe for Russian Varsovians. It ruined their orderly life, deprived many of their earnings, some even of refuge. Another worrying aspect, in addition to everyday difficulties, was the proximity of the demarcation line, behind which the Soviet troops were stationing along the Bug river. In 1939, the Russian population of the Polish Republic consisted of Polish citizens and stateless immigrants. The citizens had rights equal to those of Poles (guaranteed verbally). They were represented in the Sejm by one Russian deputy, B. A. Pimonov, an Old Believer from Wilno. ${ }^{8}$ The immigrants were holders of Nansen passports, which required frequent extending. Purchasing a property in Poland was impossible with this document. Movement around the country was limited to the settlement zone. The entry to the easternmost voivodeships was allowed only with special permission. Despite all this, the Russians lived a rather safe life in Warsaw - even the immigrants. The country for once enjoyed abundance. Finding work that suited one's knowledge and education was not difficult. The ties with Poland of many residents dated far back. The war affected them just as much as it did affect their Polish neighbours. ${ }^{9}$

At the time of Warsaw's surrender to the German troops, three émigré organisations operated in the city: the Russian Charity Society in Poland (Russkoye blagotvoritelnoye obshchestvo $v$ Polshe), the Russian Social Committee in Poland (Rossiyski obshchestvenny komitet $v$ Polshe) and the aforementioned Russian Committee for Care of Immigrants in Poland. Following the capitulation of the

7 A. Jastrzębski, “Życie na krawędzi”, in: Życie na krawędzi. Wspomnienia żołnierzy antyhitlerowskiego wywiadu, ed. W. Kozaczuk, Warszawa, 1980, p. 90.

8 The Sejm and the Senate of the Republic of Poland had five members of Russian descent: Matvey Kasperovich, b. 1869 in Volkovysk, d. 1939?, representative of the Bloc of National Minorities from the Poleskie Voivodeship in the First Term Senate; Pavel Korol, b. 1890 in Biała Podlaska, d. 1939?, elected to the Second Term Sejm in 1928 as representative of the Russian National Unity from the District no. 60 (Pinsk); Arseni Pimonov, b. 1863 in Biały Dwór, d. 7 January 1939 in Wilno, elected to the Third Term Senate in November 1930 as representative of the Nonpartisan Bloc for Cooperation with the Government from the Wilno District; Boris Pimonov, b. 1901 in Wilno/Vilno, d. 1961 in Millville, representative of the Nonpartisan Bloc for Cooperation with the Government from the Swięciany and Brasław districts in the Third, Fourth and Fifth Term Sejm (1930-39); Nikolai Serebrennikov, b. 1873 in Ostrów near Łomża, d. 1951 in Warsaw), representative of the Russian National Unity Club in the First Term Sejm; see: Polski słownik biograficzny, vol. 26, Wrocław, 1981, pp. 324-326 (Arseniusz Pimonov) and 326-327 (Boris Pimonov); vol. 3, Warszawa, 1995-96, p. 299-300 (Nikolai Serebrennikov); Postowie i senatorowie Rzeczypospolitej Polskiej 1919-1939. Słownik biograficzny, vol. 3: K-Ł, eds. P. Majewski, G. Mazur, Warszawa, 2005, pp. 174-175 (Pavel Korol).

9 С.Л. Войцеховский, “Эпизоды”, in: Русская эмиграция в борьбе с большевизмом, ed. С.В. Волков, Москва, 2005, р. 401. 
capital, the German commandant of Warsaw (Kommandant der Kommandantur Warschau), Generalleutnant Conrad von Cochenhausen was visited, already on 1 October 1939, by a delegation organised by the Russian Social Committee. The envoys welcomed the German general with gratitude on behalf of the entire Russian population of Warsaw (in reality, the delegation did not represent the entire diaspora, and its activity did not enjoy widespread support). The Board for Russian Emigrants (Vertrauensstelle der Russischen Emigranten / Upravlenie delami russkikh emigrantov; UDRE) was then established by the German authorities.

In July 1940, the authorities issued a decree on the dissolution of all Russian organisations that existed in Poland before the entrance of the German troops. Consequently, the name UDRE was assigned to the pre-war Russian Committee. The organisation had about 10 thousand registered members; after the Soviet invasion of Eastern Poland, many Russians fled westwards, and therefore their number in Warsaw increased significantly. The Germans also formed a Ukrainian, a Belarusian and a Caucasian committee. ${ }^{10}$ Sergei Voytsekhovski, brother of aforementioned Yuri, acted as representative of the interests of Russian émigrés before the Polish authorities until 1939, and during the German occupation alike. $\mathrm{He}$ was the plenipotentiary leader of the Russian Social Committee in Warsaw, then transformed into the Russische Vertrauenstelle. The communists from the Polish Workers' Party did not differentiate between Russian and Ukrainian organisations at all, as evidenced by one of the Soviet documents:

On behalf of the Polish Workers' Party [Polska Partia Robotnicza, PPR] dominated by the workers of Praga, [Józef] Kanorzewski, member of the municipal committee [member of the Warsaw Committee of the PPR, and later brigadier general of the Civic Militia [Milicja Obywatelska, MO], chief commander of the MO, and president of the Customs Office], declared, in a conversation with an employee of the Political Department [Red Army captain] Bagonowski [Bagnowski], that before the liberation of Praga, the UNO [Ukrainian Nationalist Organisation] had been operating in the city with up to 300 members. The members of this organisation are now present in the city, headed by the Orthodox priest Panin. The organisation consists of two branches: armed troops, which the Germans

${ }^{10}$ Russian officers' organisations quickly began to be established in the territories annexed by the Third Reich and in the General Government, Prior to the war, the Polish government successfully hindered the activities of such unions in the territories of the Second Republic. In April 1940, in accordance with Order no. 22, the Association of Russian Military Unions (Obyedineniye russkikh voynskikh soyuzov; ORVS) comprised the following units in occupied Poland and territories incorporated into the Third Reich: Department 7 (Danzig [Gdańsk], Warthegau: Posen [Poznań], Litzmannstadt [Łódź], Kalisch [Kalisz] - headed by Col. D.I. Khodnev [Chodniew] and the Eastern Department (General Government, headed by Gen. Maj L.M. Yerogin [Jerogin]); see: В.И. Голдин, “Солдаты на Чужбине Русскиий Обще-Воинский Союз, Россия и Русское Зарубежье в XX-XXI Веках” (2011), p. 258, in: http://militera.lib.ru/research/0/pdf/goldin_vi01. pdf (access: 17 January 2017); and К.К. Семенов, “Берлинский узел РОВСа (1920-1945)”, Ежегодник Дома русского зарубежья, 2012, р. 37. 
use to protect industrial sites, and propaganda officers. In [left-bank] Warsaw alone, this organisation has a larger membership (up to 500 people) and is headed by [Sergei] Voytsekhovski (employee of the Gestapo [sic!]), and Markiewicz (lawyer). The organisation has weapons at its disposal. ${ }^{11}$

\section{The two generals}

First of all, two military figures with the highest ranks. Born during the reign of Alexander III, General of a brigade (equivalent to major general) Stanislav BulakBalakhovich (Stanisław Bułak-Bałachowicz) considered himself equally a Russian, a Belarusian and a Pole. ${ }^{12}$ His name is linked with several former officers of the Russian army, who found themselves again under his command during the defence of Warsaw. Earlier, Gen. Bulak-Balakhovich, as Reserve Officer, had reported for service on 3 September 1939 to General Walerian Czuma. Bulak-Balakhovich's headquarters were originally located at 72 Marszałkowska Street, and then transferred to the building at 3 Litewska Street. His substitute was Lt.-Col. Nikolai Shustrov-Stanislavski (Nikołaj Szustrow-Stanisławski), a war-disabled veteran Stabsrittmeister (Staff riding master or Staff cavalry master), chief of staff of volunteer people's unit of Ataman Bulak-Balakhovich. Other Russian nationals have also fought in September 1939: quartermaster and colonel/stabs-kapitan of the tsarist army, Mikhail Yakovlev (Michait Jakowlew) (ataman of the Composite Cossack Division with the Polish Army in 1920); “colonel” Iosif Yurchenko (Józef Jurczenko) (officer of the tsarist army); rotmistrz (rittmeister) Yevgeni Shteynike (Eugeniusz Sztejnike) (officer of Bulak-Balakhovich's army); lieutenants Ado, Verner (Werner), Valtsev (Walcew); second lieutenants Kachanovski (Kaczanowski), Ladkovski (Ładkowski); and master sergeants (choraży) Kastorov (Kastorow) (war-disabled veteran missing one arm), Lobachevski (Łobaczewski) (Cossack officer of former Bulak-Balakhovich's army). But the fate of some of them proved unenviable. Col. Stanislavski was ultimately arrested on 31 March 1940, then imprisoned. The Germans executed him on 21 June 1940 at Palmiry, near Warsaw. As for Yakovlev,

${ }^{11}$ Central Archive of the Ministry of Defence of the Russian Federation (Центральный архив Министерства обороны Российской Федерации, hereinafter: ЦАМО РФ), f. 233, о. 2380, d. 23, fol. 144, Запись переговоров по прямому проводу члена Военного совета 1-го Белорусского фронта К.Ф. Телегина с заместителем начальника Главного политического управления Красной армии И.В. Шикиным о событиях в г. Варшаве по состоянию на 22.15 30 сентября 1944 г.

12 When analysing Bulak-Balakhovich's policies, one might notice a certain "blurring of borders", evidenced by military and conspiratorial activity in anti-Bolshevik milieus, whose members either emphasised their Belarusian origin, or clearly favoured cooperation with the structures of Russian post-revolutionary diaspora. But even though the Wilno-based Ataman Degacz might be considered a mythoman in the light of his attempts to consolidate mutually exclusive political programs, Bulak-Balakhovich definitely should not; see: W. Stanisławski, Myśl polityczna, p. 140. 
he was arrested in April 1940 and sent to Auschwitz, where he died in July next year. Shteynike (Sztejnike) was arrested in 1940 too, and died at the Pawiak prison. ${ }^{13}$

Since 6 September 1939, Bulak-Balakhovich's men ("Balakhovites") were responsible for mounting the defences of the Wilanów and Czerniaków areas as part of the $4^{\text {th }}$ Operational Group of the Warsaw Defence or "Group C" (Marek Cabanowski indicates that the "detached outpost" was first established at Okuniew, and then transferred to Wilanów). The troops commanded by Bulak-Balakhovich consisted of two infantry battalions, two cavalry squadrons, one officer-cadet company, one anti-tank artillery battery, one officers' platoon, one reconnaissance platoon, and one gendarmerie platoon, as well as the French-Czechoslovak "foreign legion" battalion, which amounted in total to 1,800-2,000 soldiers and 250 horses (but only 1,600 rifles and 200 sabres). A second version states that BulakBalakhovich commanded over just only one reinforced infantry company and one improvised cavalry squadron of 100 men, which were stationed at the Wilanów quarters (farm estate, school, and parish of Rev. Jan Krawczyk). These units fought in the vicinity of the pre-war villages of Okuniew, Wilanów, Czerniaków, Służew, Natolin, Moczydło, and later near Marymont and Bielany. Even before the beginning of the full siege of Warsaw, on 9 September 1939, Gen. Bulak-Balakhovich sent his envoy to create volunteer units in Brest, Lublin and Wilno; on the same day a skirmish occurred near Otwock. The Balakhovites' reconnaissance report contained the following details: "e) The partisan unit of Gen. Bulak-Balakhovich reporting, as of 9 a.m. all over the area from Grodzisk to Błonie and Pruszków no more than 120 tanks divided into three groups. Warsaw is being shelled with captured cannons". ${ }^{14}$

Two days later, a patrol noticed the presence of German tanks on the outskirts of Służew, apparently sent to explore the area. On September $12^{\text {th }}$, Col. Romanowski managed to break through the encirclement near Wołomin; his group would remain active until the battle of Kock. At the same time, Bulak-Balakhovich's soldiers retook Służewiec and its famous local racecourse, at a price of 50 killed and wounded. The Balakhovites also patrolled the outskirts south of Wilanów. Around noon on September $16^{\text {th }}$, Bulak-Balakhovich's cavalry engaged in combat in Natolin, supported by an infantry unit under the command of Res. Lt. Kazimierz Feliks Wagner. Unfortunately, the Polish cavalrymen charged the positions of German

13 J. Janowski, “Dziennik zastępcy dowódcy obrony Warszawy w 1939 roku”, in: Obrona Warszawy 1939 we wspomnieniach, eds. M. Ciepielewicz, E. Kozłowski, Warszawa, 1984, pp. 145-146; M. Cabanowski, Generał Stanisław Bulak-Balakhovich. Ostatni Kmicic II RP i wyklęci żotnierze wojny polsko-sowieckiej 1920 r., Warszawa-Kraków, 2013, pp. 179-180; А. Кручинный, П. Мицнер, “Генерал Станислав Булак-Балахович в 1939 году”, Новая Польща, 121 (2010), no. 7-8, pp. 67-74.

14 Obrona Warszawy w 1939 r. Wybór dokumentów wojskowych, comp. M. Cieplewicz, Warszawa, 1968, p. 41 (“nr 25: Meldunek sytuacyjny nr 3 dowództwa grupy gen. W. Czumy, 9.09.1939”); and Cabanowski, Generat Stanisław Bulak-Balakhovich, p. 181 
machine-gun emplacements near Natolin. This was of course a proof of their heroism, but also of a lack of prudence or basic strategic thinking. ${ }^{15}$

Here is how the chief of the Warsaw Defence Staff perceived the activities of the Balakhovites: "Towards the south-west, we control the entire area stretching to Wilanów and further south. Wilanów was in the hands of Gen. Bulak-Balakhovich and his group of volunteers. One night, one company of $360^{\text {th }}$ Infantry Regiment patrolling the Wilanów-Wolica-Służewiec route came across a German detachment in the village of Wolica; usually, the Germans would recall their remote outposts at night". ${ }^{16}$ The next day, the situation remained precarious at Wilanów: "The central part of Wilanów was being shelled; the enemy then launched an assault on our units in Wilanów (Gen. Bulak-Balakhovich). According to unconfirmed reports, the enemy advanced rushing women and children ahead, in order to approach our positions using them as shields". ${ }^{17}$

The most successful operation of the Balakhovites proved to be the night mission of September $18^{\text {th }} / 19^{\text {th }}$ under the command of Lt.-Col. Shustrov-Stanislavski. Six heavy machine guns and 23 cases of ammunition have been seized. In recognition of his merit, the commander was promoted to the rank of colonel and decorated with the Silver Cross of the War Order of Virtuti Militari, V Class. The volunteer group of Gen. Bulak-Balakhovich was later relocated, and fought, since September $23^{\text {rd }}$, in the northern part of Warsaw (Marymont). Their last mission was to reclaim, on September $26^{\text {th }}$, the Bielany Woods and the Camaldolese monastery in Bielany. The command of the $4^{\text {th }}$ Operational Group was taken over on that same day by Col. Shustrov-Stanislavski, by order of Bulak-Balakhovich. But this operation was halted by the surrender of the capital. The total number of losses in BulakBalakhovich's units amounted to 78 commissioned and non-commissioned officers, and 399 privates. $^{18}$

After the surrender of Warsaw, Bulak-Balakhovich co-founded the Military Confederation. Late in the evening of 10 May 1940, several young members of

15 Polish historians mention another roster of the staff of Gen. Bulak-Balakhovich's group: chiefof-staff Maj. Mieczysław Szczudłowski, spec. task off. Res. Lt. Eugeniusz Pichell, inf. div. comm. Res. Lt. Kazimierz Feliks Wagner, cav. div. comm. Rotmistrz Stanisław Zagojski; see: Cabanowski, Generał Stanisław Bulak-Balakhovich, pp. 181-182; Warszawa we wrześniu 1939 roku. Obrona i życie codzienne, eds. C. Grzelak, Warszawa, 2004, p. 512; Кручинный, Мицнер, Генерал Станислав Булак-Балахович, pp. 67-74; and K. Kanabus, Wilanowski Wrzesień 1939 r., www.gazetawilanowska.pl/wilanowski-wrzesien-1939-r/ (access: 17 January 2017).

16 T. Tomaszewski, "Byłem szefem Sztabu Obrony Warszawy w 1939 r.”, in: Obrona Warszawy 1939 we wspomnieniach, pp. 103-104.

17 Obrona Warszawy w 1939 r. Wybór, p. 227 ("nr 173: Meldunek sytuacyjny nr 19 Dowództwa Obrony Warszawy z dnia 17 września do godz. 20.00; 18.09.1939”).

18 The unit used the following names: Voluntary Group of General Bulak-Balakhovich, Special Operations Group, South-Western Operational Group, Operational Group III, Operational Group IV and Partisan Headquarters; see: Cabanowski, Generał Stanisław Bulak-Balakhovich, pp. 185-187; and M. Piekarski, Samotna placówka, Warszawa, 1989, p. 172. 
the general's organisation gathered in the villa where he lived, at 27 Paryska Street (some sources mention 103 Saska Street). As soon as they heard a police car stop under their windows, they rushed to leave the place. Bulak-Balakhovich stepped outside in the company of several people. They approached the patrol the German Order Police (Ordnungspolizei). Suddenly, the general lifted the cane he used for support. He delivered a powerful blow to the head of the patrol commander, killing him on the spot. He was pierced by a hail of bullets in response. The confusion among the German officers only lasted a few seconds, but it was enough time for the young people to flee. It remains a matter of conjecture whether the general decided to sacrifice his life to save the conspirators, or this was an involuntary burst of his hatred for the Germans.

Another version links Bulak-Balakhovich with the national Military Organisation Lizard Union (Organizacja Wojskowa Związek Jaszczurczy, OW ZJ), whose name is a reference to the historical rivalry between Poles and Teutonic Knights in the $15^{\text {th }}$ century. Their activities began with the inaugural meeting of 14 November 1939. Among its participants were Władysław Marcinkowski, Henryk Suchodolski, and Paweł Janczukowicz; Jan Pożaryski and Wiktor Radziszewski also joined a few days later. The aforementioned far-right activists managed to initiate contact with several Polish officers known for their unfavourable attitude toward Piłsudski's camp, and thus interested in bringing to life a more conservative resistance movement. Among them were several generals (Stanislav Bulak-Balakhovich, Tadeusz Jastrzębski, Józef Plisowski, Mieczysław Poniatowski, Radosław DzierżykrajStokalski) and colonels (Julian Skokowski, Tadeusz Kurcyusz). Unfortunately, more accurate information on the activity of General Bulak-Balakhovich is unavailable. ${ }^{19}$

The Military Confederation's cooperation with the far-right impacted negatively on its assessment by the commander of the Union of Armed Struggle (Zwiazek Walki Zbrojnej, ZWZ). In his semi-annual report, Gen. Stefan Rowecki, nom de guerre "Grot" (Arrowhead), referred to "organisations not cooperating with the Association for Social Self-Defence/Self-Support" (Stowarzyszenie Samoobrony/ Samopomocy Społecznej, codename of ZWZ):

Military Confederations (stamp with state emblem and inscription "National Volunteer Army - Div. Gen. Stanislav Bulak-Balakhovich” [sic! - Reserve Brigade General]) a small group composed of former subordinates of Bulak-Balakhovich. Among its members are Gestapo officers, several Poles and some White Russians. General B[alakhovich] was killed by the Germans on Francuska [Paryska] Street in front of his house in unexplored circumstances. Previously important and active, now they seem idle. Cooperation

19 K. Komorowski, Polityka i walka. Konspiracja zbrojna ruchu narodowego 1939-1945, Warszawa, 2000, p. 256; and W.J. Muszyński, Duch młodych. Organizacja Polska i Obóz Narodowo-Radykalny w latach 1934-1944. Od studenckiej rewolty do konspiracji niepodległościowej, Warszawa, 2011, p. 217. 
in conspiratorial conditions is excluded. If they ever produce something of value, I might reconsider for the uprising. ${ }^{20}$

The Military Confederacy allegedly survived until May 1941, but only Poles would serve in it. Subsequently, the conspirators from Bulak-Balakhovich's organisation joined the ZJ/NSZ (National Armed Forces; Polish: Narodowe Sity Zbrojne) and ZWZ/AK (Home Army; Polish: Armia Krajowa) structures; among them was, for instance, Witold Wincenty Przyborowski ("Kulesza"), who was appointed commander of the sapper platoon in the Home Army "Miotła" Battalion. ${ }^{21}$

Another Russian officer, who had reached the rank of major general before the end of World War II, was Boris Smyslovski [Borys Smystowski] (a.k.a. Artur Holmston, or von Regenau). Most people associate him with the Wehrmacht uniform and collaboration with the Germans. During the civil war, he served as artillery officer in the Armed Forces of the South of Russia (Vooruzhyonnyye sily Yuga Rossii; VSYuR), and then in the $3^{\text {rd }}$ Staff of the Russian Armed Forces of Lt.-Gen. Nikolai Bredov. After almost a decade spent in Poland, Smyslovski graduated from the German General Staff Academy at the turn of the 1920s and 1930's After completing a reconnaissance course in Truppenamt, he initiated cooperation with the German military intelligence. During WWII, he served as Sonderführer (K) (equivalent to Hauptmann or Rittmeister) within Stab Walli I-III and Sonderstab R. ${ }^{22}$

Under the name "von Regenau", Smyslovski made contact with the Polish underground, namely the intelligence organisation Muszkieterzy (the Musketeers), which cooperated with the British MI6. In October 1941, the Polish organisation received, from Maj. Smyslovski and 2nd-Lt. Vladimir Bondorevski (Włodzimierz Bondorowski), a proposition of assistance in the transfer of a group of officers behind Soviet lines, to the Polish Army under Div. Gen. Władysław Anders. Both the two Russians and the organisation's leader, Stefan Witkowski ("Inżynier"), independently hoped for acquiring intelligence information and reaping political benefits from the joint action. The head of ZWZ intelligence, Col. Marian Drobik ("Dzięcioł"), even noted the inclusion of two officers in the operation. "Inżynier" allegedly asserted that the Chief Commander of the ZWZ, Gen. Stefan Rowecki ("Grot") was aware of the situation. The possibility of initiating courier communication with Gen. Anders seemed an attractive alternative. The role of couriers was entrusted to rotmistrz Czesław Szadkowski ("Mikołaj Zaręba") and three officers representing three types of military branches: 2nd-Lt. Czesław Wasilewski "Wilk"

20 Armia Krajowa $w$ dokumentach 1939-1945, vol. 1, part 2: Wrzesień 1939 - czerwiec 1941, eds. A. Suchcitz, W. Grabowski et al., Warszawa, 2015, p. 926 ("Dok. 251: Generał Rowecki do gen. Sosnkowskiego - Meldunek półroczny o stanie organizacyjnym ZWZ w Generalnym Gubernatorstwie, na ziemiach wcielonych do Rzeszy i pod okupacją sowiecką").

${ }^{21}$ Cabanowski, Generał Stanisław Bulak-Balakhovich, pp. 192-194.

22 И. Грибков, И. Ковтун, Д. Жуков, Особый штаб “Россия”, Москва, 2011, pp. 32-66. 
(infantry), Lt. Kazimierz Rutkowski "Mątwa" (artillery), and podchorąży (Officer Cadet) Antoni Pohoski "Korejwo" (aviation). The Poles set off on 3 December 1941 to Kharkov in the company of Bondarevski, and next travelled via Lubyanka to Buzuluk, where Gen. Anders' headquarters were located. Smyslovski has also supposedly begun cooperating with the anti-communist organisation "Miecz i Pług" [Sword and Plow], infiltrated by the NKVD/NKGB agent Bogusław Hrynkiewicz ("Alexander") since summer 1942. He then sought contact with the Home Army; concurrently, the AK was investigating into his opinions and entourage. Allegedly, there have also been attempts of initial talks regarding an alliance between White Russia and the Home Army. ${ }^{23}$

The information obtained by AK counter-intelligence did not discredit the Russian officer in spite of his cooperation with the Germans:

Smyslovski Boris, lieutenant colonel, reportedly officer of the tsarist guard, Chief of Staff of the ROA [correctly Sonderstab R], with his office at N[owy] Świat Street [in fact, it was the Pusłowski House at 5 Nowy Świat Street; Smyslovski's second office was located in a tenement in Chmielna Street]. Of Finnish descent, with significant influence in Finland, Latvia and Estonia. Maintains a decidedly anti-communist stance, but not pro-German either. Expresses great respect for Anglo-Americans, has good knowledge of the activity of Polish conspiratorial circles, reads conspiratorial press with attention. In general, he approaches Polish matters with understanding. ${ }^{24}$

Two Warsaw telephone books from 1940 and 1942 listed several other Smyslovski's ventures. He co-managed a locksmithing company (Schlosserei) with Bondorovski at 61 Hoża Street, phone number 897 40, and the company "Corporation" Mikucki R. u. Smyslowski B. GmbH Schleifmittel Wohn (sandpaper factory, representative office of Norddeutsche Schleifmittel-Industrie in Hamburg) at Neue Burgstraße 46 (Nowogrodzka Street), phone number $73533 .{ }^{25}$

${ }^{23}$ Archive of the Institute of National Remembrance (hereinafter: AIPN) BU, 01222/3114, Notatka informacyjna, 18.07.1952 [Information note], fol. 69; Грибков, Ковтун, Жуков, Особый штаб, pp. 148-149; K. Leski, Życie niewłaściwie urozmaicone. Wspomnienia oficera wywiadu i kontrwywiadu AK, Warszawa, 1989, pp. 129-131; J. Rostkowski, Świat Muszkieterów. Zapomnij albo zgiń, Poznań, 2016, pp. 176-183; R. Spałek, Komuniści przeciwko komunistom. Poszukiwanie wroga wewnętrznego w kierownictwie partii komunistycznej w Polsce w latach 1948-1956, PoznańWarszawa, 2014, pp. 405-407; P.P. Wieczorkiewicz, Historia polityczna Polski 1935-1945, Poznań, 2014, p. 404; and Д. Жуков, И. Ковтун, “Борис Хольмстон-Смысловский и НТС. История сотрудничества и противостояния”, in: История отечественной коллаборации. Материалы и исследования, Москва, 2017, р. 316.

24 AAN, 228/8-2, Społeczny Komitet Antykomunistyczny - "Antyk" (Komitet rosyjski, Pułk. Smysłowski), 17.03.1944 [Social Anti-Communist Committee "Antyk" (Russian Committee, Col. Smyslovski)], fol. 95.

25 Amtliches Fernsprechbuch für den Distrikt Warschau 1942, Warschau, 1942, p. 34, 114 and 160; and Telefonverzeichnis der stadt Warschau [list of active telephones within the Warsaw network], Warschau, 1940, pp. 121 and 166. 
At the same time, Smyslovski had several private addresses; before the war, he lived at 19 Parkowa Street (phone 884 20). His second address is mentioned in the 1942 telephone book, where he is listed again with the title of engineer at 8 Radna Street (phone 313 62). Smyslovski's third address appeared in the Home Army's counter-intelligence reports, which determined that he was living near the platform of the Warsaw-Wilanow narrow-gauge railway line at 32 Belwederska Street. ${ }^{26}$

This fact has probably not gone unnoticed by the Germans either, who accused Boris Smyslovski of being a double agent and sentenced him in December 1943 to house arrest. At the same time, the intelligence structures and sabotage units under his command have been disbanded. Smyslovski's internment was prompted by a tip from a Swiss journalist of Russian origin, Alexander Würgler, to the Commander of the Security Police in the District of Warsaw (Komandeur der Sicherheitspolizei Warschau, KdS Warschau) regarding Smyslovski's associations with Freemasonry and British intelligence. Würgler thus took revenge for a similar act by Smyslovski, which led to his exclusion from Sonderstab Russland. However, he was promptly assassinated, two days before Christmas, in Warsaw's Old Town; most likely by the Home Army, although other probable perpetrators cannot be ruled out, such as: KdS Warschau, communists affiliated with the PPR/ GL-NKVD/NKGB, Smyslovski's subordinates, or his competitors from the People's and Workers' Union of Russian Solidarists (NTS). Half a year later, Smyslovski has been cleared of all charges. However, despite the realisation that Smyslovski's activity was not directed against the Polish Underground State, the Home Army responded (in an inexplicable way) on 17-18 May 1944 with an unsuccessful attempt to assassinate this "colonel of the Ukrainian Army". His misidentification as a Ukrainian in the action briefing could have exacerbated the fighting moods of the soldiers of the Directorate of Diversion $(K e D y w)$ of the AK District of Warsaw, well aware of the tragic fate of the Poles in Volhynia and Eastern Galicia during Ukrainian's OUN/ UPA/UNS massacre. ${ }^{27}$

${ }^{26}$ Amtliches Fernsprechbuch, p. 160; Spis abonentów sieci telefonicznej m.st. Warszawy P.A.S.T. i warszawskiej sieci okręg P.P.T.T. Rok 1939/40 [lists of telephone subscribers in Warsaw area], Warszawa, 1939, p. 392.

27 AAN, 228/8-2, Społeczny Komitet Antykomunistyczny - “Antyk”, Referat rosyjski, Załącznik nr 4, 8.12.1943 [Social Anti-Communist Committee "Antyk", Russia Bureau, Annex no. 4], fol. 87; Генерал Власов. История предательства, vol. 1: Нацистский проект "Aktion Wlassow”, ed. А.Н. Артизов, Москва, 2015, р. 855 (№. 315. Донесение сотрудника отдела «иностранные армии Востока» при Генштабе окх оберлейтенанта Баума генерал-майору р. Гелену о персональном составе штаба А.А. Власова и антинемеияих установках членов этого итаба, 10.01.1945); S. Aronson, P. Bukalska, Rysiek z Kedywu. Niezwykłe losy Stanisława Aronsona, Kraków, 2009, p. 99; J.D. Zimmerman, The Polish Underground and the Jews, 1939-1945, Cambridge - New York, 2015, pp. 332-333; and "Uciekłem z transportu, trafiłem do Kedywu. Ze Stanisławem Aronsonem, pseudonim 'Rysiek' rozmawia Marcin Urynowicz”, Biuletyn Instytutu Pamięci Narodowej, no. 8-9 (2008), pp. 131-132. 
Stanisław Aronson, soldier of the Disposition Unit "Kolegium A" (KeDyw of the AK District of Warsaw), participated in this operation:

One traumatic memory of mine was the failed attempt to eliminate Boris Smyslovski. It went on for two days, without any result. "Żbik” [2nd-Lt./Lt. Zdzisław Zajdler-Rybicki] died in the course; losing a commander after 10 months of fighting together was a terrible blow. That day, we were waiting at the terminus of the Wilanowska [Konstancińska] railway line. Trains were departing and arriving, but we were still there, and that gave us out. "Rena" [Renata Brenstiern-Pfanhauser, Rostworowska from 1948] noticed two narks, who found us suspect. Moments later, “Żbik” ordered immediate retreat. But it was already too late; he and "Kaczor" [name unknown] did not make it. They were attacked by the German police and killed at the entrance to the building on Olszewska Street. The others managed to flee. Now it turns out that they died for nothing, and that we were probably carrying out a mission ordered by Soviet agents within the British Secret Intelligence Service, those from Kim Philby and the "Cambridge Five". Smyslovski was indeed an enemy of the Soviets, not Poles, whom he knew very well, as he had been living in Warsaw since the 1920 s. $^{28}$

The report on Smyslovski drawn by the AK counter-intelligence service two weeks after the failed assassination attempt contained a completely different picture, which should not lead to a death sentence. The Russian officer in German service had been, even before the war, a member of the Martinist Order and the symbolic lodge of the Ancient and Primitive Egyptian Eastern Rite of Memphis-Mizraim known as "Pyramid of the North in the Vistula Valley" no. 16 (La Pyramide du Nord en Vallée de la Vistule). ${ }^{29}$ Here is an excerpt from a report on a friend of Smyslovski's, Jan Korwin Czarnomski:

28 Testimony of Stanisław Aronson, 4 August 2012, from the author's archives.

29 In the 1930s, the Ancient and Primitive Eastern Egyptian Rite of Memphis-Mizraim had just a few members. Its core consisted of Jan Korwin Czarnomski "Elpher", acting as Grand Master of Lights, i.e. head of the organisation; Boris Smyslovski "Hermes", chairman of the "Pelikan" chapter and Grand Conservator of the Rite, and Robert Walter "Waltari", Grand Koft and Secret Counsel. The other members of the rite were: Stanisław Korwin Czarnomski (Jan's brother) and Ryszard Walter (Robert's brother). A rivalry occurred within the rite until 1937 between J. Czarnomski and Smyslovski, who then "synchronised" their efforts; Smyslovski would conduct intelligence activities in the northern and Germanic countries. The "information" about the desintegration of the Fédération Universelle des Ordres et Sociétés Initiatiques (FUDOSI) can be considered a rumour. In spite of his service in Fremde Heere Ost, the Russian remained loyal to his lodge during the war: in early 1944, he assisted J. Czarnomski (or R. Walter in late 1943, according to other reports) in transporting the rite's archives to Budapest; see: Central Military Archive (Centralne Archiwum Wojskowe, hereinafter: CAW), IX.3.26.3, Armia Krajowa. Komenda Główna, Oddział VI, Walter Robert - Tajny Zakon Martynistów i Memphis Misraim [Home Army HQ, Sect. VI (actually II B: counter-intelligence), Bur. 996, report on Walter Robert], fol. 17; CZARNOMSKI Jan - brat ELPHER Wielki Mistrz obrządku Memphis Misraim i Martynistów - zabity 260744 [report on Czarnomski Jan - frater Elpher (...), killed 26 July 1944], fol. 29; AIPN BU, 01222/ 3144, Odpis: Borys Smysłowski [copy:], fol. 23; Z. Łagosz, "Robert Walter's Struggle with the UB: the Unknown Story”, Studia Religiologica, 46 (2013), no. 4, pp. 298-299. 
He maintained here the links with Col. S[myslovski] established in Paris. He thought very highly of Mr. S[myslovski], stressing his kindness to Poles and his efforts in saving those who have been sentenced to death. In one case, he allegedly pulled a detainee out of a car that was taking him to the execution site. In the autumn of 1943 (in November), he was asked by Col[onel] S[myslovski] to accompany him as private secretary to France. [...] I would like to stress here that Col[onel] S[myslovski] has informed Cz[arnomski] that the ultimate goal of this expedition would be to establish contacts with the Allies, as they will surely prevail in the war. ${ }^{30}$

The information provided by the Home Army's counter-intelligence service is supplemented by the testimony of a former Home Army officer, who later worked as an agent of the UB. Here is what agent Juliusz Wilczur-Garztecki, confined to the same cell as the oblivious Robert Walter (friend and freemason confidant of Smyslovski), reported after the war:

He is convinced that, due to his friendship with, the Ministry of Public Security [Ministerstwo Bezpieczeństwa Publicznego, MBP] will want to use him as "bait". [...] At the request of Walter, Smyslovski used his connections to conduct an investigation into the murder [of Czarnomski] and determined that Piwnicka [Katarzyna, Czarnomski's fiancée] was associated with some underground organisation. [...] I informed Walter that, according to my sources from S[ection] II of the Home Army, Czarnomski had been assassinated by Andrzej Sudeczka's band [group] at the behest of S[ection] II of the NSZ based on the so-called "list of Judeo-Bolsheviks in the AK staff". ${ }^{31}$

Smyslovski remained loyal to his lodge when, at the beginning of 1944, he supported Czarnomski in the transfer of the organisation's (lodge) archives to Budapest. Czarnomski asked Smyslovski to verify whether Katarzyna Piwnicka ("Ketti”), worked for KdS Warschau. The Russian discovered that "Ketti" was actually working for a detective agency. After the war, the UB accused Piwnicka of cooperation with the intelligence service of the Warszawa-Miasto Regional Delegation of the Polish Government "Wiry-Mury" headed by Wiktor Boczkowski ("Korwin"). Prior to this, Czarnomski used to express, in conversations with friends, his dissatisfaction that Piwnicka did not work for the Intelligence Service. In addition, he warned him against her, as she allegedly was one of the key members of the so-called "Korwin" Brigade (Lt.-Col. Franciszek Wiktor Boczkowski-Boćkowski), i.e. one of the branches of the ZWZ-AK counter-intelligence service operating in Warsaw. ${ }^{32}$

30 AAN, 203/ VII-4, Oddział II Informacyjno-Wywiadowczy Komendy Głównej AK, 996-W, Jan Czarnomski; 10.07.1944 [Sect. II of AK HQ, 996-W, report by "Wacław" on Jan Czarnomski], fols. 19-20.

31 AIPN BU, 00168/79, folder 8, Teczka pracy krypt. "Natan” [Oper. file, Wilczur-Garztecki Juliusz], fols. 238, 241; and Łagosz, Robert Walter's Struggle, pp. 298-299 and 303-304.

32 CAW, IX.3.26.3, Armia Krajowa, Komenda Główna, Oddział VI, Piwnicka Katarzyna - Ketti, fol. 20; O. Borzęcki, "Brygada Korwina w szeregach ZWZ-AK w latach 1941-1943", Dzieje Najnowsze, 47 (2015), no. 3, p. 52; and Łagosz, Robert Walter’s Struggle, pp. 304-305. 
One of the conspirators raised this subject in his report based on performed reconnaissance: "According to his knowledge [counter-intelligence officer Adam Leszczyc-Gutowski ("Bratkowski”)], "Ketti” was a secretary of Smyslovski, which allowed "Korwin" to obtain comprehensive information about the entire staff of Vlasov's Army [Sonderstab Russland]". But in the latter part of the same document, this information was challenged by Czarnomski's answers from his discourse with a counter-intelligence officer of the Home Army:

Czarnomski claims that she was in love with him, and that he once even considered proposing to her, which, however, he was advised against by Smyslovski, who drew his attention to the fact that "Ketti" could constitute a threat to him. [...] "Ketti" asked Czarnomski to help her with a certain matter, which, as he claims, only Smyslovski could resolve. As a result, $\mathrm{Cz}$ [arnomski] put her in touch with Smyslovski, and according to him [i.e. to Czarnomski], she paid him a visit once in Vlasov's headquarters [Sonderstab Russland], and then tried to maintain contact by calling him on various pretexts, at which, according to Czarnomski, she did not succeed. Smyslovski pointed out to Czarnomski that Piwnicka's behaviour resembled that of a G[esta]po informant, yet he had no concrete evidence to prove his claim, as it was based purely on a personal impression. [...] "Ketti" has strong connections in the conspiratorial world, especially with NSZ circles. ${ }^{33}$

Due to his internment, Smyslovski was helpless in saving his freemason friend. Jan Czarnomski died on 27 June 1944, killed by unknown perpetrators. The incident could have been a robbery, an erroneous assassination due to a resemblance of names with Professor Eugeniusz Czarnowski, ${ }^{34}$ or an operation directed against left-wing factions of the resistance movement, Freemasons and Jews, thus connected with the murder of Ludwik Widerszal and Jerzy Makowiecki perpetrated by soldier of the diversionary unit of Andrzej Popławski ("Andrzej Sudeczko"), subordinate to the Governmental/State Security Corps (PKB). Also suspected were members of Henryk Glass's organisation, "Blok", originating from the pre-war Anti-Communist Committee, and operating as Bureau "W" within Section II of

${ }^{33}$ CAW, IX.3.26.3, Armia Krajowa, Komenda Główna, Oddział VI, Piwnicka Katarzyna - Ketti [AK HQ, Sect. VI (actually II B), Bur. 996, report on Piwnicka Katarzyna - Ketti], fols. 20-21.

34 Eugeniusz Czarnowski, noms de guerre: "Adam", "Lidzki", "Piotr", "Piotr Kostrzewa" (17 November 1904, Łódź - 30 December 1947, Warsaw); chairman of the Democratic Alliance (Zjednoczenie Demokratyczne), member of the Council of National Unity (Rada Jedności Narodowej), captain of the Home Army (AK); economist by profession. Delegated by the Home Army in February 1943 to conduct negotiations with the PPR over their cooperation. President of the Main Board of the Union of Free Poland (Zwiazek Wolnej Pol$s k i$ ), and in the early 1944 associated with the Democratic Alliance, which he represented in the Chief Commission of the Council of National Unity, and at the same time, from 1941 on, he cooperated with the underground Democratic Party and its official newspaper Nowe Drogi. 
the Home Army Headquarters, and as the Observational Brigade "Lisy" (Brygada Obserwacyjna "Lisy") within the NSZ. ${ }^{35}$

After the assassination attempt by the Home Army, Col. Smyslovski maintained relations only with the NSZ. Since late 1944, Smyslovski's staff cooperated with a liaison patrol of the Holy Cross Mountains Brigade (Brygada Świętokrzyska), composed of: Lt. Przemysław Andrzej Łebiński (after the war: Władysław Przemysław Szaława / Przemysław Mieczkowski), noms de guerre "Władysław" and "Przemysław Szaława", Capt. Zdzisław Przybył ("Rafał Olbromski"), and Lt./ RAF Flying Officer Richard V. Tullet ("Harry"), ${ }^{36}$ who had joined the NSZ after escaping from a POW camp. A few weeks before the end of the war, on 1 April 1945, the $1^{\text {st }}$ Russian National Division / Special Division R (1. Russische Nationaldivision/Sonderdivision $R$ ) was renamed as $1^{\text {st }}$ Russian National Army (1. Russische Nationalarmee, 1. RNA) allied with Germany. Smyslovski was promoted to the rank of Major General of the Wehrmacht. Polish emissaries from the NSZ were often present at the headquarters of "von Regenau". On 10 April 1945, Lt. Łebiński was dispatched with the task of establishing contact with the command of the Polish $2^{\text {nd }}$ Corps in Italy (via Germany, Switzerland and France). During his stay there, he was assigned to the Officers' Reserve of the $7^{\text {th }}$ Infantry Division. He returned to the Świętokrzyska Brigade on 5 July 1945.

In the last days of April 1945, Maj. Gen. Smyslovski and his last remaining soldiers of the 1. RNA, as well as Grand Duke Vladimir Romanov, successor to the Russian throne, and Sergei L. Voytsekhovski (mentioned above), all fled to Liechtenstein. This independent principality refused to hand the general and his subordinates over to the Soviets. It was actually possible, as the Yalta agreements on the repatriation of Soviet citizens and POWs did not cover the neutral territory of Liechtenstein. ${ }^{37}$

35 CAW, IX.3.26.3, Armia Krajowa. Komenda Główna, Oddział VI, Walter Robert - Tajny Zakon Martynistów i Memphis Misraim [Home Army HQ, Sect. VI (actually II B), Bur. 996, report on Walter Robert], fol. 17; S. Bojemski, "Likwidacja Widerszala i Makowieckich", Glaukopis 20072008, no. 9/10, p. 370; and J. Marszalec, "Morderstwo na Makowieckich i Widerszalu. Stara sprawa, nowe pytania, nowe wątpliwości”, Zagłada Żydów. Studia i Materiały, 2 (2006), p. 47.

${ }^{36}$ Probably it was a British pilot, but it could have also been an officer of the British Security Service, or MI5 (Military Intelligence, Section 5) - the assumption seems to be supported by Tullet's disappearance after he reached together with the BŚ liaison officers to the general staff of the Polish $2^{\text {nd }}$ Corps in Italy. Meanwhile available Bomber Command's list of RAF pilots, who were shot down and became prisoners of war, only contains the name of a bomber pilot: Sgt. Tullett R.M., $77^{\text {th }}$ RAF Bomb Squadron, who was shot down on the night of 16-17 April 1943 during a raid on Pilsen, while piloting a Handley Page Halifax KN-W (JB908). After being taken captive, he eventually found himself a prisoner of Stalag 357 (Thorn [Toruń]); see: https://www.forces-war-records.co.uk/records/4158477/sergeant-r-m-tullett-royal-air-force/ (access: 17 January 2017).

37 Rozkazy dzienne Brygady Świętokrzyskiej Narodowych Sił Zbrojnych 1944-1945, comp. C. Brzoza, Kraków, 2003, pp. 209-210; A. Bohun-Dąbrowski, Byłem dowódcą Brygady Świętokrzyskiej NSZ Pamiętnik dowódcy, świadectwa żołnierzy, dokumenty, Warszawa, 1989, pp. 149, 172; and Грибков, Ковтун, Жуков, Особый штаб, рр. 278-279, 288-297 and 312-314. 


\section{The Kotlyarevski brothers}

During German occupation, fate brought together Stefan Korboński, member of the Political Consultative Committee (Polityczny Komitet Porozumiewawczy; PKP) and head of the Directorate of Civil Resistance under the Polish Government Delegate's Office (Komitet Walki Cywilnej przy Delegaturze Rządu RP na Kraj, KWC), with several Russian émigrés. During German occupation, a tragic incident struck "Russian" Warsaw. At its centre were the Kotlyarevski [Kotliarewski] brothers, whose release Sergei Voytsekhovski had sought in vain during numerous encounters with influential officials of the German administration:

Among such [Polish] "agents" were some Russians, including the former editor of Nashe Vremya ${ }^{38}$ and Russkoye Slovo, T.A. [Feoktist, or Teokryt, Ananevich] Kotlyarevski and his brother - Yevgeni [or Eugeniusz, Ananevich]. ${ }^{39}$

In T.A. Kotlyarevski's apartment [at 6/4 Zgoda Street], a relative of his, a Pole, has been arrested for carrying illegal Polish prints. It was enough a reason for everyone who lived there to be arrested; the next day, T. Kotlyarevski and his relative [should be: relatives] were accused of being "agents", which was punishable by death. All the efforts of S.L. Voytsekhovski, President of the Russian Committee, to save T. Kotlyarevski ended in failure, and a few days later we read Kotlyarevski's name again, this time on the list of recent executions. His brother died because of his own carelessness; when all these people were getting arrested, he was not home. The Gestapo officers have shut the empty apartment and confiscated the keys. The next day, E.A. Kotlyarevski, having learned of the arrests, ignored all warnings from his friends, and made the careless decision of going to the Gestapo in order to retrieve the keys. He would never return, and a few days later, he too appeared on the list of executed "agents". Both Kotlyarevski brothers were well known in our Russian community and, of course, were no "agents", nor did they participate in the activities of Polish anti-German organisations.

I thought so in 1943, but now I know that the attempt to save T.A. Kotlyarevski from execution was not just ineffective, but plain hopeless. A[natoli] P. Velmin was actually

${ }^{38}$ Nashe Vremya was published under the editorship of G.A. Matsiyevski (1930-1932), then S.M. Goryachko (from October 1932 to July 1933), and finally T.A. Kotlyarevski; the editorial board was based in Wilno, and had branches in Warsaw and Lwów. In Wilno, it was assembled in E.A. Kotlyarevski's printing house, just as Russkoye Slovo (a new incarnation of Nashe Vremya, differing only in title). The Kotlyarevskis' newspaper was distributed together with a Russian-language newspaper from Riga, Segodnya (in fact, Nashe Vremya was a regional supplement to Segodnya).

39 Yevgeni Kotlyarevski, as an experienced publisher and journalist, joined Józef Mackiewicz and Czesław Ancerewicz as co-owner to publish the Wilno/Vilno daily Goniec Codzienny, under supervision of the German Propaganda Abteilung. Teresa Jurgielewiczowa had an unflattering opinion of Kotlyarevski ("of a tarnished reputation", "had also been sentenced [to death]"). This second information is contradicted by Lucjan Krawiec ("Kotlyarevski's case, as he was not a Pole [but a Russian], did not undergo any judgement or sentencing by the Special Court"); see: W. Bolecki, Ptasznik z Wilna. O Józefie Mackiewiczu. Zarys monograficzny, Kraków, 2013, pp. 275, 279 and 303. 
wrong when he suggested that T. Kotlyarevski had not been involved in the struggle of Polish secret organisations against German occupiers. I learned the truth in 1954, from the memoirs of the former leader of the Polish resistance, the lawyer Stefan Korboński. ${ }^{40}$

Here is what Stefan Korboński wrote in his post-war memoirs about the three Russians cooperating with the Home Army and the Directorate of Civilian Struggle under the Polish Government Delegate's Office:

At the beginning of 1944 [in 1943], [...] our headquarters were located on [6/4] Zgoda Street, near Chmielna Street, in the apartment of Professor [Doctor] of Botany Wiszniewski [Tadeusz Wiśniewski] ${ }^{41}$, or rather his White Russian father-in-law, the editor of a Russian émigré magazine based in Warsaw [Wilno] prior to the war. He would often open the door to me, but we never engaged into conversation. Over time, Wiszniewski began to work for us; for instance, he would keep our papers in his herbaria. Several thousand files with dried plants laid on wooden shelves in his room, and we used them as our temporary archive. Wiszniewski once told me that his father-in-law not only avoided those White Russians and those of their organisations in Poland [General Government] that collaborated with Germany - sometimes just for better ration stamps - but he even believed that after many years of experiencing Polish hospitality, the Russians should never pursue policies contrary to the interests of their [occupied] hosts. Perhaps there were some other reasons as

40 Войцеховский, Эпизоды, pp. 405-407 (Voytsekhovski was a correspondent of the Russian-language newspaper Novoye Slovo. He fled on 30 July 1944 from Warsaw to Germany).

41 Tadeusz Wiśniewski (b. 25 May 1905 in Taganrog, d. 30 November 1943 in Warsaw). Botanist (University of Warsaw, PhD in 1930) and phytogeographer, mountaineer, scientist. He was an expert and collector of moss, and an enthusiast of science and research expeditions. Wiśniewski travelled to Bulgaria, Yugoslavia, Lapland; he participated in an expedition to the Caucasus (1935), Ruwenzori (1939) and others places. The African expedition "cost" him his post at the Warsaw University. However, these journeys allowed him to complete numerous, valuable herbaria - mosses in particular. He conducted botanical research in the Tatras. In 1923, Wiśniewski published several articles and botanical works, partly about the flora of the Tatras. His most important work was the dissertation: "Les associations de Muscinées (Bryophyta) épiphytes de la Pologne, en particulier celles de la forèt-vierge de Białowieża (Zespoły mszaków epifitycznych Polski ze szczególnym uwzględnieniem Puszczy Białowieskiej)" published in Bulletin international de l'Académie polonaise des sciences et des lettres, Classe des sciences mathématiques et naturelles, Série B, I Cracovie, (1929), no. 8-10. The collection survived the war, having been concealed at the State Museum of Zoology. Wiśniewski was preparing a monograph on Polish mosses, which he did not finish due to his premature death. After the outbreak of the German-Polish war, he fled to the Polesie Hydrobiological Station in Pińsk; from there, he travelled to Lviv, only to return to Warsaw in 1941. During World War II, he participated in underground education in Warsaw. He assisted in the evacuation and concealing of the archives of the Department of Plant Systematics and Geography of the University of Warsaw. He was arrested by officers of KdS Warschau, and executed on 30 November 1943 with other hostages at 63 Solec St., near the Trinitarian church; see: A. Iwaszkiewiczowa, Dzienniki i wspomnienia, Warszawa, 2000, p. 599; A. Skirgiełło, Powstanie i rozwój Zakładu Systematyki i Geografii Roślin Uniwersytetu Warszawskiego (w zarysie), Warszawa, 2001, pp. 12-13 and 15-16; Bolesław Hryniewiecki, "Tadeusz Wiśniewski (1905-1943). Wspomnienie pośmiertne”, Acta Societatis Botanicorum Poloniae, 19 (1948), no. 2, pp. 275-280. 
well, such as the reluctance towards undertaking joint action with Germany against Russia (even Soviet Russia); but it was far enough that we had his apartment at our disposal. ${ }^{42}$

In the autumn of 1943, the German authorities arrested a certain Wosiński, who, following torture, brought their attention to Tadeusz Kiełczewski ("Rudy"), secretary of the KWC. A few days later, having succeeded in obtaining details from another conspirator, KdS Warschau officers appeared at KWC premises in Zgoda and Leszczyńska Streets. The ambush at the first site brought the arrests of Stanisław Kętrzyński, Tadeusz Wiśniewski, Teokryt Kotlyarevski, and his spouse, Nina. Korboński continued:

I spoke to Wiszniewski [Wiśniewski] and I demanded that everyone leave the apartment, at least for some time, and hide. I offered financial support, forged documents, etc. Wiszniewski refused, however, arguing that if arrested, "Rudy" would never reveal anything, given how tough and relentless he was; Wiszniewski also asserted his father-in-law and wife strongly have refused to leave the apartment, and finally, that the apartment has been completely emptied of documents and the Gestapo would not find anything there. I nodded my head, doubting nonetheless. When it comes to torture, I would never vouch for anyone, even for myself. How can one know? But anyway... I could not force them. And what if "Rudy" had not been arrested, but managed to flee to the countryside instead? My head was already filled with concern related to the disappearance of "Rudy", that I stopped thinking about the apartment in Zgoda Street. A few days later, bad news struck. The Gestapo had raided the place at night and taken everyone away. [...] In the fourth year of the war, our minds have become dull in these matters, and no one would react as lively as they did at the beginning of the occupation. [...] I almost suffered a breakdown nonetheless when, on a certain morning, my eyes came across the names of Wiszniewski and his father-in-law on a red poster bearing the names of people that had been publicly executed. I checked several times in disbelief. All in all, I was not prepared for such a sudden end. But sadly, it was an undeniable fact. The big black letters on the red background clearly spelled: "Wiszniewski". Such was the end of a young, promising scientist, but that of a noble Russian man as well - an unexpected sacrifice in our struggle against the Germans. ${ }^{43}$

The Germans killed all the detainees except Kętrzyński. The execution of both Russians and dr. Wiśniewski fell within the implementation of "Kutschera's harsh course". The period of increased repression in the Warsaw district of the GG ended on 1 February 1944, when Franz Kutschera, SS- und Polizeiführer Warschau, SS Brigadeführer und Generalmajor der Polizei, was successfully eliminated by the KeDyw of the Home Army HQ. ${ }^{44}$

42 S. Korboński, W imieniu Rzeczypospolitej, Warszawa, 2009, p. 318.

43 W. Grabowski, Polska Tajna Administracja Cywilna 1940-1945, Warszawa, 2003, p. 248; and Korboński, W imieniu Rzeczypospolitej, pp. 452-455,

44 AAN, 202/ II-17 microfilm 2225/3: (St.K.W., 25 XI 1943) [Report by Prison Unit of Government Delegate's Office - “Stożek”], fol. 22-23; (St.K.W., Ściśle tajne, 25 XI 1943) [Top secret], fol. 24; (St.K.W., 9 XII 1943), fol. 27; and Korboński, W imieniu Rzeczypospolitej, pp. 319-320. 
A third testimony about the arrest of the Kotlyarevski brothers and Wiśniewski, partly overlapping with the previous ones, states as follows:

"I have been several times to Zgoda Street. I was making forfeited certificates in Gothic script on Błoński's handmade paper; that was my task in November 1943. One day, Wiśniewski asked me for a favour. From between the covers of an old book, he pulled out concealed pieces of accordion-folded tissue paper with names and addresses. He asked me to deliver them to a specified address. [...] It was necessary to remove all traces relating to the Home Army from the places that could be known to the Gestapo. I reacted immediately. I begged him to follow me immediately to Nowogrodzka Street [...]. He refused politely, explaining that there was no such need, as he already had a place to stay [...]. Wiśniewski claimed that Nina would return soon, but it was too late to move anyway.

The police came before dawn, at 5 a.m, to arrest Wiśniewski and Kotlyarevskaya. They were entering the police car. He had no hat on, but carried a small typewriter. My friends living across the street saw the moment of their arrest, [...]. I immediately informed Mirka about this troubling incident. She was worried sick; she sent him a ration package and a beret. Getting him out of custody proved impossible. The next red list of executed hostages, posted on all the Morris columns in the city, contained his name as well. His life came to an end on 30 November 1943. One month later, on a subsequent list [14 December 1943], I found the name of [Yevgeni] Kotlyarevski, Nina's brother. He had arrived from Wilno and headed straight to the Gestapo to retrieve the keys to his sister's apartment, believing that he had nothing to fear. Nina, with her ailing liver, did not make it out of "Pawiak" either [she passed away on 10 March 1944]. ${ }^{45}$

\section{The two colonels: Vladimir Brand and Nikolai Tumanov}

Vladimir Brand [Władimir Brand] was a Russian officer, associated with NTS, Sonderstab R and the Polish resistance movement. He was born on 17 July 1892 in the Tula governorate. He has completed the Nikolayevski Cadet Corps, then graduated in 1912 from the Mikhailovskaya Academy of Artillery. He served in the Russian army until demobilisation in 1917, having attained the rank of artillery captain. In 1918, he was conscripted into the Red Army, and transferred to the Tula Brigade as commander of an independent light artillery squadron. The unit would remain under his command as part of the Armed Forces of the South of Russia and the army of the Ukrainian People's Republic. On 25 March 1919, he promoted to lieutenant colonel, to serve under Gen. Yudenich, and then in the Russian Volunteer People's Army. ${ }^{46}$

45 A. Skirgiełło, Zapiski ze stuletniego życia, Warszawa, 2006, p. 83. (“As Wiśniewski’s documents listed him as 'married', he registered Nina Kotlyarevskaya as his 'wife' during their wandering across the territories annexed by the Soviet Union. Nina first took care of him in Pinsk, but then, in order to avoid arrest, they left together for Lviv, where the roles have changed. This prompted Wiśniewski's wife, Mirka (née Sidorowicz), to file for divorce; the botanist then married Nina, and converted to Orthodoxy"; see: ibid., p. 81).

${ }^{46}$ P. Mitzner, Warszawski krag Dymitra Fiłosofowa, Warszawa, 2015, pp. 138-139. 
At the end of 1919, he emigrated to Poland, where he joined the Society for Defence of Motherland and Freedom (Soyuz zashchity rodiny i svobody) headed by Boris Savinkov. Besides being an experienced officer, he was recognised as an accomplished poet, member of the "Poets' Tavern" literary group; ${ }^{47}$ he was a member of the "Literary Community" (Literaturnoye sorduzhestvo) since the late $1920 \mathrm{~s} .{ }^{48} \mathrm{He}$ also contributed as journalist and editor to Filosofov's periodicals: For Freedom! (Za Svobodu!) from 1927 to 1932, Hearsay (Mol'va) from 1932 to 1934, and from mid-1934 to 1939, the weekly Sword (Mech).$^{49}$ Brand did not neglect his lyrical activity either; in 1932, he published the poetry collection Poems (Stikhi), printed on a duplicating machine in Warsaw, and then he co-authored Antologiya russkoy poezii v Polshe (anthology of Russian poetry in Poland), published in Warsaw in 1937, as well as the poetry collection Nov'. ${ }^{50}$

Sergei Voytsekhovski wrote of Brand's literary and journalistic engagement as follows:

47 The Poets' Tavern (Taverna poetov): a Warsaw-based literary circle founded in early 1921 by Alfred Bem. Besides Brand, the Tavern comprised, among others, Vsevolod Baykin, O. Voynov, Boris Yevreinov, and Aleksandr Turintsev. The journalist Dmitri Filosofov was also a close collaborator. The group maintained close relations with members of the Skamander literary movement. In 1923, the Poets' Tavern published a collection of poems and short stories entitled Shestero. Maly almanakh poezii i prozy. The Poets' Tavern ceased to exist after two years; see: П. Лавринец, “К истории Виленского содружества поэтов", Literatura, 2002, no. 44; I. Obłąkowska-Galanciak, “Из истории русской эмиграции (“Таверна поэтов” - Варшава 1921-1925)", in: Literatura rosyjska na emigracji. Wspólcześni pisarze rosyjscy w Polsce. Frazeologia i frazeografia. Materiały konferencji naukowej (9-10 listopada 1995 r.), eds. W. Skrunda, W. Zmarzer, Warszawa, 1996, p. 77-81; В. Станиславский, “Русская эмиграция в Варшаве”, Новая Польша, 2002, nо. 5, pp. 17-22.

48 The Literary Community existed from 1929 to 1935 . Originally, it functioned as the literary section of the Russian Writers' and Journalists' Association (Soyuz russkikh pisateley i zhurnalistov). Its meetings were held twice a month, and were attended - besides Brand - by other writers such as: Dmitri Filosofov, Lev Gomolitski, Anton Dombrovski, Sonya Kindyakova, S.P. Kuntsevich, and S. Voytsekhovski. The Russian writers and poets also invited Polish colleagues, such as Julian Tuwim and Kazimierz Wierzyński; see: Т. Исмагулова, “Русская эмиграция в Польше (Владимир Бранд - поэт и воин “русской Варшавы”)”, in: Зарубежная Россия 1917-1939 г2.: Сборник статей, еd. В.Ю. Черняев, Санкт-Петербург, 2000, pp. 346-347; and Ł. Dryblak, "Czy tylko prometeizm? Polityka państwa polskiego wobec wybranych kół emigracji rosyjskiej w latach 1926-1935”, Studia z Dziejów Rosji i Europy Środkowo-Wschodniej, 51 (2016), no. 1, p. 100.

49 Brand was also co-editor and columnist for the supplements: "Unity. Free tribune of youth" ("Yedineniye. Volnaya tribuna molodezhi"), "In his corner" ("V svoyem uglu"), and "Association" ("Obyedineniye"). Mech was unofficially considered a periodical of the NTS. The most influential figures in the editorial board were D. Filosofov, W. Brand and G. Sokolov; see: Mitzner, Warszawski krąg, pp. 140-141; and Adam R. Suławka, "Prasa rosyjska i rosyjskojęzyczna o tematyce społecznej, politycznej i kulturalnej, wydawana w Warszawie (lata 1918-1939)", Rocznik Mazowiecki, 25, 2013, pp. 149-152.

50 В. Булгаков, Словарь русских зарубежных писателей, New York, 1993, p. 241; Dryblak, Czy tylko prometeizm?, pp. 102-103; and Mitzner, Warszawski krąg, pp. 139. 
Of all contributors to Molva, W.W. Brand was the closest to Filosofov. They shared their former participation in Savinkov's Society for Defence of Motherland and Freedom. In spite of its dissolution, Brand never abandoned engagement in political conspiracy. He was also involved in the Brotherhood of the Russian Truth (Bratstvo Russkoj Pravdy, BRP), ${ }^{51}$ and soon became one of the leading activists of the National Union of the New Generation. ${ }^{52}$

The National Union of the New Generation was established at the 1931 Second Congress. Delegates from seven countries elected the organisation's authorities, to be headed by Viktor Baydalakov (President of the Board in Belgrade) and Duke Sergei Leuchtenberg (President of the Council in Paris). The moment when the "new generationists" attracted the interest of the Eastern Bureau of Section II of the Polish General Staff remains a matter of discussion. Did the Polish intelligence agents set up the meeting between Filosofov with Würgler themselves? The Section's initiative is debatable. But what is certain is that it could not have occurred without their knowledge and consent.

Brand joined the NTS at the beginning of the 1930s, and acted as leader of the organisation's Polish branch until 1935. He cooperated with Georgi von Rosenschild-Paulin and Alexander E. Würgler. Brand set up sabotage courses in the Warsaw region, as well as an NTS operating group in cooperation with Section II of Polish General Staff, which provided support and assistance to Brand and the NTS. Mikhail Brzhestovski account brings an insight into his journey from Germany to Poland in the summer of 1939 , where a sabotage course was taking

51 The Brotherhood of the Russian Truth (Bratstvo russkoy pravdy, BRP) was founded in 1921 as an obscure, militant monarchist organisation. The supreme executive power in the organisation was held by the Brotherhood Centre - Supreme Circle (Bratski tsentr - verkhovni krug), a Russian anti-Soviet organisation of monarchist émigrés, operating in the 1920s and early 1930s. Its establishment was probably initiated by the poet and lawyer Sergei Sokolov. Among the founders were also writer Aleksandr Amfiteatrov and the Orthodox bishop Germogen, while several high-rank officers and representatives of the Russian aristocracy (generals Pyotr Krasnov, Pyotr Wrangel, Dmitri Khorvat and Duke Anatoli Liven) supported the organisation. The main objective of the BRP was the military overthrow of the Bolsheviks in Russia. Initially, the organisation provided support to partisans and conspirators fighting the Bolsheviks in Belarus, Ukraine, the Caucasus and the Far East. Their plans involved terrorist activity aimed at symbols and representatives of Soviet power (such as blowing up the Lenin mausoleum in 1930). The organisation was eventually dismantled by baron A.N. Kolberg, agent of the Joint State Political Directorate (OGPU) and one of the leaders of the Brotherhood until September 1932. The BRP cooperated closely with the ROVS and NTS. The Brotherhood published the periodical Russkaya Pravda. The organisation itself ceased to operate in 1933.

52 Войцеховский, Эпизоды, p. 393. Chronology of NTS name changes: 1927: Union of Russian National Youth (Soyuz russkoy natsionalnoy molodyozhy, SRNM); 1929: National Union of Russian Youth Abroad (Natsionalny soyuz russkoy molodyozhy za rubezhom, NSRM); 1931 - National Union of the New Generation (Natsionalny soyuz novogo pokoleniya, NSNP); 1937 - National Workers' Union of the New Generation (Natsionalno-trudovoy soyuz novogo pokoleniya, NTSNP); 1943 - People's and Workers' Union (of Russian Solidarists) (Narodno-trudovoy soyuz [rossiyskikh solidaristov], NTS). 
place at Baydalakov's behest. The training, which lasted eight weeks (June-July), included such subjects as: adaptation to "Soviet" principles of everyday life and terminology used in everyday conversations, study of the Bolshevik party and Soviet apparat, topography of the border regions as well as the geography of the entire country, railway networks, encrypted correspondence, photography, unconventional lock picking, use of guns and revolvers, and endurance exercises in the form of 60-70 km walks. The lecturers were Polish officers of the II Department of Polish General Staff (Oddział II SG WP), also called Dwojka, as well as Georgi Okolivich, Aleksandr Kolkov, Aleksandr Chuprunov, and presumably Vladimir Brand. The Polish military intelligence service enabled the smuggling of NTS members across the Soviet border and prepared copies of documents for them. Russian authors note that the NTS maintained complex relations with the "Polish underground" after 1939, and had "contacts with the Jewish ghetto in Warsaw" ${ }^{53}$

Voytsekhovski described Brand's period of operation in the following words: "The Germans - it ought to be said - did not immediately notice the existence of national minorities in Poland. They did not seek to persecute the Russian emigrants who, in the first days of the war, would call for resistance against Germany. For instance, they did not repress the editors of the Warsaw-based periodical Mech, W. W. Brand and G. G. Sokolov. ${ }^{54}$ Brand went on to become one of the leading members of the NTS, and during World War II, he served in Sonderstab Russland and the Russian Liberation Army (Russkaya osvoboditelnaya narodnaya armiya; ROA). He nonetheless attracted the suspicions of KdS Warschau.

In the autumn of 1941, the NTS worked on establishing an organisational network in Minsk and Vitebsk, as well as a centre in Smolensk, where the association obtained support from the city's mayor, Boris Myenshagin. "In 1941, the Union (after some name changes) dispatched him, as many other of its members, in the territories of Russia [USSR] occupied by the German troops. In March of the following year [16 March 1942], Brand died of typhoid in Smolensk". ${ }^{55}$

53 Исмагулова, Русская эмиграция, pp. 348-351; А. Окулов, В борьбе за Белую Россию. Холодная гражданская война, Москва, 2013, р. 316; От Зарубежья до Москвы. Национально-Трудовой Союз (НТС) в воспоминаниях и документах 1924-2014, еd. В. Сендеров, Москва, 2014, р. 23 (Борис Пушкарев, НТС в истории русского сопротивления) and pp. 92-95 (Михаил Бржестовский, Свидание с родиной).

54 С.Л. Войцеховский, Эпизоды, р. 393.

55 Following the outbreak of the German-Soviet War, the smuggling of NTS members from the General Government to the occupied territories of the Soviet Union began in July 1941. These operations were coordinated by the head of the Polish branch of the organisation, Alexander Würgler. The emissaries obtained travel documents, although some travelled without these, in whichever way possible. As a result, more than 250 people from Serbia, Bulgaria, the Protectorate of Bohemia and Moravia, Slovakia, France, Belgium, Germany, the General Government and the Baltic States were relocated to the occupied Soviet territories, meaning that 1 in 5 NTS members had left their home; see: AIPN BU, 185/340, file 1, No. 6075/3, Опертивиная сводка No-58, Агентурно-Следственная работа, Народный Коммиссар Внутренных Дел БССР, 
The poet and military officer Vladimir Brand himself wrote, as if he had predicted his fate:

Что ждет нас там? Восторг иль муки

В родной, неведомой стране?

Несли ей сердце, мозг и руки,

Молясь в осенней тишине...

What awaits us there? Bliss or pain

In our unknown motherland?

They carried its heart, brain and hands,

Praying in autumn silence... ${ }^{56}$.

In the summer of 1942, Artur Ritter ${ }^{57}$ made acquaintance with a Russian immigrant, the engineer (Col.) Nikolai Tumanov [Mikołaj Tumanow], who possessed a phenomenal memory and almost encyclopaedic knowledge of the White Russian immigrant community not only in the General Government, but in other European countries as well. Nikolai Tumanov born 1 April 1887 or 5 May 1887 in St. Petersburg, son of Pavel and Yekaterina, née Kanin. Prior to that, he graduated from the Saint Petersburg Polytechnic Institute (1908-13), then was conscripted in 1915, and assigned to the $9^{\text {th }}$ Army as lecturer of engineering works; he attained the rank of colonel. He was head of personnel in the army of General Wrangel. He then spent some time in Kiev and Rovne. Tumanov relocated in Poland on 15 July 1919, when the Polish troops seized the city. He found work at the Water Management Department of the Ministry of Public Works. Tumanov married a Polish woman, but they divorced before the outbreak of World War II.

Старшый майор ГБ, Цанава, Секретарю ЦК КП/б/ Белорусской ССР, 25 ноября 1939 г. Минск, fol. 5; and Łagosz, Robert Walter's Struggle, pp. 102-106 and 108-109. Obituary notice of Vladimir Brand, in: Novoye Slovo (Berlin), 1942.

56 W.W. Brand, “Из стихов, написанных по пути в Смоленск 11.11.1941”, in: Исмагулова, Русская эмиграция, pp. 345-352.

57 Artur Ritter-Jastrzębski, noms de guerre: “Andrzej”, "Bogdan”, "Stefan”, “(Wilhelm) Tell” (b. 12 May 1906 in Oryel, d. 7 May 1981 in Warsaw): Member of the Communist Party of Poland since 1927. A graduate of military and political courses of the Polish Section of the Communist International, he was assigned to the Central Military Department of the Polish Communist Party. In the spring of 1941, after training, he was appointed personnel officer of the NKVD/NKGB. He worked for the Soviet military intelligence by intermediary of Czesław Skoniecki ("Ksiądz"), head of the Special Department of Central Committee (KC) of the Polish Workers' Party (PPR), officially subject to the Comintern intelligence service, and unofficially to the NKVD/NKGB. He was an active member of the PPR. He played an important role in Soviet intelligence operations in Warsaw and the General Government. Jastrzębski infiltrated the organisation "Miecz i Pług" on behalf of the Soviet intelligence. He participated in the joint PPR-NKVD/NKGB-SD operation, consisting in the appropriation of the Archive of the Security Department of the Polish Government Delegate's Office. His insight into KdS Warschau allowed him to liberate three NKVD/NKGB operators from the prison in Szucha Avenue in July 1944. 
He would later work as engineer at the "Praga" factory. During the occupation, he lived at 2 Grzybowska Street, 7/2 Wiejska Street, 34 Rozbrat Street. ${ }^{58}$

Ritter learned from Tumanov about the existence of the Ofitserskoye sobraniye in Warsaw, ${ }^{59}$ which attracted the interest of the NKVD/NKGB, leading to an investigation into the organisation. After numerous "business deals" Ritter managed to befriend Tumanov, whom he impressed with his excellent knowledge of Russian and literature. Tumanov was an admirer of Lermontov, Pushkin and other Russian poets, was a virtuoso guitar player, and "sang quite pleasantly". The Russian hated Germans in general, but considered Ritter an exception, and acquainted him to the milieu of White émigrés. He used to introduce him by saying: "A German, but a Russophile". In a rush of sincerity, and under the influence of alcohol, he told Ritter: "What German are you, you're truly one of us (Kakoj ty Niemiec, ty nasz orłowskij)". After some time, Tumanov moved to the same tenement as Ritter in the German district (34/36 Rozbrat Street), which allowed the NKVD/NKGB agent to maintain regular, almost daily contact with the Russian. ${ }^{60}$

Owing to their close relations and his discreet observation, Ritter got to know Tumanov to the point that he decided to recruit him to work for the NKVD/NKGB, with the approval of his superiors (one should mention that Ritter-Jastrzębski was also nominally a member of the PPR and the People's Guard [Gwardia Ludowa]). In late 1942, he invited Tumanov to a restaurant on Krakauerstrasse (Krakowskie Przedmieście Street); later, as they were passing by the Europejski Hotel, he addressed Tumanov in Russian:

"Kola, your motherland needs help. I appeal to you as a Soviet intelligence officer [NKVD/ NKGB] who knows you are honest man, and that you cannot consent to the criminal fascism that is destroying your country and mine. Enough of this madness!". Tumanov

58 AIPN BU, 0-423/2603, Karta ewidencyjna nr B/21/53/45, 5.07.1946 [Registration card], fol. 11; Wyciąg z teczki S.R.C, 9.02.1950 [Excerpt from SRC file], fol. 14 (5.05.1887); Komunikat 1995/50, 3.04.1950 [Communiqué from invest.], fol. 17 (1.04.1887).

59 Ofitserskoye sobraniye: Russian émigré organisation in Warsaw, founded back in the 1920s. The Soviet spy made a mistake in his memoirs, since the organisation was actually the eastern branch of the Association of Russian Military Unions (ORVS). In 1943, it numbered about 800 members and was headed by General Valerian Trusov (b. 30 September 1879 in Mikhalkovo, Ryazan governorate, d. 24 December 1957 in New York City). During the inter-war period, he lived in Lublin, and was an active member of Russian veterans' and monarchist organisations. Head of the Polish branch of the Russian All-Military Union, renamed as ORVS on 22 October 1938; see: O. Beyda, "Iron Cross of the Wrangel's Army. Russian Emigrants as Interpreters in the Wehrmacht”, Journal of Slavic Military Studies, 27 (2014), no. 3, p. 432; and Голдин, Солдаты на Чужбине, р. 285.

${ }^{60}$ Archive of Historical Documentation of the Polish People's Republic (hereinafter: ADH PRL), Collection of Walery Namotkiewicz N-I/29, Uncensored memoirs of Artur Jastrzębski "Życie na krawędzi”, comp. Stanisław Majewski, no date, fols. 151-153; and Życie na krawędzi. Wspomnienia, pp. 87-88. The typescript of the memoirs was published in the aforementioned compilation, deriving its title from Ritter-Jastrzębski's memoir. 
stopped and stood motionless, then grabbed me by the arm, and looked me straight in the eye, unable to utter a word. We stood in silence for a moment. Suddenly, I noticed tears in his eyes. He clutched my hand and wept. There, in front of me, stood a man exhausted by life, who felt so far useless to everyone; and now his motherland was asking him for help in times of need. The motherland he had lost.

After a dozen moments, he mastered himself and replied quietly: "Artur, I will never be a communist, and I would do anything for my motherland. Anything!" That was his first reaction. He asked for a day to consider the matter. I agreed, as it could not have been otherwise. I understood perfectly that he should, or even had to simmer down, that he wanted to stay alone, all alone with his thoughts. I said goodbye and left. Tumanov went in a different direction, under discreet observation set up by Skoniecki [Czesław Skoniecki ("Ksiądz"), head of the Special Department of the Central Committee of the PPR, head of the NKVD/NKGB network in Warsaw], who had been forewarned about the operation. It was found that Tumanov went straight home, and did not leave until the next morning. We met the next day. I was greeted by a completely new man: rejuvenated, smiling, energetic. "I have been thinking over your proposal", he declared, "and I accept it. Waiting for orders!”61.

Soon, they co-founded a fictitious shipping company, which allowed them to move freely around the General Government, and created the appearance that Tumanov had a solid and substantial income, thus lending credibility to the various receptions, meetings and soirees he organised in order to invite people deemed of worth for the intelligence.

An intelligence agent with a favourable reputation in a large environment that sympathises, or even collaborates with the enemy, is an inexhaustible source of valuable information. Nikolai Tumanov fulfilled this role within the White community of Warsaw. The people in this environment, motivated by talkativeness, vanity, or envy about influence and reputation, would reveal all their contacts and various matters, both important and trivial. This constituted an inexhaustible source of often captivating knowledge for the intelligence [NKVD/NKGB]. [...] Kola worked with dedication. He was bursting with joy as he reflected on his reclaimed motherland, and exalted with pride in that he could serve his country in such a difficult time. There were times when I had to restrain his impulses, and even criticise him for disregarding various dangers". ${ }^{62}$

This is how Nikolai Tumanov's activity was described after the war by 2nd-Lt. Wiesław Gawor, officer of the SB and superior of Nikolai's grandson Włodzimierz (Włodek), in a note about the latter: “Tumanow’s grandfather was a tsarist officer, a [R] ussian national. He fled from Russia after the October Revolution. During World War II, while living in Warsaw, he cooperated with

61 ADH PRL, Collection of Walery Namotkiewicz N-I/29, Uncensored memoirs, fols. 156-157; and Życie na krawędzi. Wspomnienia, pp. 89-90.

${ }^{62}$ ADH PRL, Collection of Walery Namotkiewicz N-I/29, Uncensored memoirs, fols. 158-159; and Życie na krawędzi. Wspomnienia, pp. 90-91. 
Soviet counter-intelligence services [NKGB]. As a former White officer, he was entrusted in making contact with officers of Vlasov's army stationing in Warsaw". ${ }^{63}$ Owing to his friendships among émigrés, and to freshly discovered capacities, Tumanov managed to acquire essential sources of information, taking advantage of the obliviousness of the Varsovian Russian community. He proved masterful at arousing spirits and untying tongues. The nature and outcome of Tumanov's activity are accurately depicted in another fragment of Ritter-Jastrzębski's memoirs:

He knew the Russian soul, and which notes to hit to obtain a response. Once, as I recall, he invited a Cossack [sic! - dragoon] Colonel [Ivan] Sevasteyev ${ }^{64}$, who showed up grim as a hail cloud. At first, he behaved stiffly, choosing to remain distant and rather silent; he spoke sparingly. Kola was generous with premium liquors, strummed the strings and sang old Russian songs so touching, that even the toughest soul could not help but weep. At one point he asked the guest, "Vanya, do you remember your regiment song?"

He stroked the strings and sang with a voice so powerful, that Sevasteyew immediately forgot about everything, thumped his chest with his fist, joined the song, wept, and eventually tore his shirt to shreds. Eskadronnaya pesnya - the regiment song. In Tsarist Russia, it was customary that each regiment have its own song.

In similar circumstances, we learned for instance that the son of the old émigré Brunner [Nikolai Brunner, nom de guerre "Krasnov"?] was departing on a certain day with a large sum of money to Pskov, where saboteurs would be smuggled from to the rear of the Red Army. On another occasion, we learned that Shapovalov would be going to Kharkov for the same reason...

The young Brunner would not have yet boarded the train the Warsaw, when the Headquarters in Moscow would have already notified the intelligence cell in Pskov about the expected visit, in order to take steps to eliminate the emissary. There were times when Tumanov's guests would express, in our presence, their astonishment in the extraordinary operability of Soviet counter-intelligence, given that the agents sent by Berlin to the USSR were eliminated one after another. ${ }^{65}$

Ritter equipped his agent; for instance, he provided Tumanov with an accidentally purchased tapestry with the portrait of Tsar Nicholas II, produced at Żyrardów on the occasion of the $300^{\text {th }}$ anniversary of the Romanov House. Moreover, they planned an attempt on the life of Gen. Andrey Vlahos, the "commander" of the Russian Liberation Army:

63 AIPN BU, 00 1121/4399, Notatka służbowa dot. studenta II roku Wydz. Filozofii Chrześcijańskiej Akademii Teologii Katolickiej, Włodzimierza Tumanowa, 20.03.1980 [Operational note on Włodek Tumanow, $2^{\text {nd }}$ year student at the Faculty of Christian Philosophy of the Catholic Academy of Theology], fols. 25-26.

${ }^{64}$ Ivan Sevasteyev (1876 - 23 Dec. 1951) was born in St. Petersburg. His military service began in 1893; he graduated from the Tver Cavalry School in 1898. He was promoted to the rank of Colonel in the $15^{\text {th }}$ Dragoon Regiment. In exile in Warsaw, then in Germany. He died on 23 December 1951 in Deventer (Netherlands). Married; see: С. Волков, Офицеры Армейской Кавалерии, http://forum.vgd.ru/post/174/60778/p1760346.htm (access: 17 January 2017)

${ }^{65}$ ADH PRL, Collection of Walery Namotkiewicz N-I/29, Uncensored memoirs, fols. 159-160; and Życie na krawędzi. Wspomnienia, p. 91. 
One day, we were informed that Gen. Vlasov intended to visit Warsaw. I immediately delivered this message to the Headquarters. Along with the information, I inquired whether an attempt on Vlasov's life could be carried out, should favourable circumstances arise. [...]

The answer came quickly; obviously, they ordered the elimination of the traitor.

With the consent of the Headquarters, I prepared a detailed plan of action, which would take place at a banquet prepared in honour of Vlasov, organised on the occasion of his announced arrival to Warsaw. Tumanov and I knew the details of the event. We were also provided with invitations, which would facilitate the supervision of the operation. Suitable individuals were selected to perform this task.

Vlasov, however, proved to be no fool, knowing what to expect in a city like Warsaw. He arrived without announcement, avoided the émigrés and spent less than two hours in the city before departing further east. Under these circumstances, our plan had completely failed. Upon liberation, I experienced some unpleasantness because of this. It turned out that Stalin himself was involved in this matter, and that the decision came from him; I had therefore failed to accomplish Stalin's order. ${ }^{66}$

Since 1944 Tumanov transferred to Cracow at 21 Boczna Street (21/8 Szymanowski Street), and then to Częstochowa on Old Square (Stary Rynek). Col. Tumanov had three sons, two of whom died as Home Army soldiers during the Warsaw Uprising. An extract from the Foreigner Registration Office (Sekcja Rejestracji Cudzoziemców; SRC) reveals that on 19 January 1947, he was chairman of the commission in Sandomierz during the fraudulent election to the Legislative Sejm, where he cooperated with UB officers. He must have spent a long time in the countryside, as "he arrived in Warsaw in October 1948 from Byłwany, Sandomierz county, and settled at 18/3 Poligonowa Street, where he used to be visited by an individual unknown to the informants, with whom he spoke in Russian. On 9 June 1949, he changed his registered address to 17/16 Ząbkowska Street" ${ }^{67} \mathrm{He}$ then lived at 5/19 Dzielna Street in Warsaw. After obtaining Polish citizenship on 22 September 1951, he worked as an inspector in the Department of Construction of the Ministry of Public Security. He was an active member of the Aviation League. Despite this, he was under the regular surveillance by the UB as "class enemy", as evidenced in a note by UB Capt. Rudnik, mentioning that "tsarist Colonel Tumanov" had been a "member of the Nationalist Russian Committee in Warsaw". ${ }^{8}$

${ }^{66}$ ADH PRL, Collection of Walery Namotkiewicz N-I/29, Uncensored memoirs, fols. 161-162; and Życie na krawędzi. Wspomnienia, pp. 92-93 (the exact term used here is "superiors' order"; an effect of censorship during Gierek's era).

67 AIPN BU, 0-423/2603, Notatka służbowa dot. opracowania akt archiwalnych nr 1465/IV, 14.11.1949 [Oper. note on comp. of archival data], fol. 1; Komenda Milicji Obywatelskiej m.st. Warszawy, Szef Sekcja Rejestracji Cudzoziemców Komendy MO st. Warszawy do Ewidencji Ludności m.st. Warszawy, L.dz. 1761-Ref 49, 22.06.1950 [Warsaw MO HQ, Head of the For. Reg. Sect.], fols. 9-10; AIPN BU, 0-423/2603, Karta ewidencyjna nr B/21/53/45, 5.07.1946 [Registration card], fol. 11; Wyciąg z teczki S.R.C., 9.02.1950 [Excerpt from SRC file], fol. 14.

${ }^{68}$ AIPN BU, 0-423/2603, Komunikat 1995/50, 3.04.1950 [Comm. from invest.], fol. 17; Notatka informacyjna płk. "D”, 31.10.1951 [Inform. note by Col. "D”], fol. 21; Informacja Dep. II MBP 
The following information was filed during investigation on Tumanov by Section II, Department III of the MBP, based on annexed documents no. DB-928/51 dated 24 March 1953 and GMB/I/71/53 dated 19 March 1953, and notes of agent "Pewny" of 27 November 1952, as reported by Capt. Adasiak, deputy Head of the Department of Staff of the Voivode's Office of Public Security (Wojewódzki Urząd Bezpieczeństwa Publicznego, WUBP) in Warsaw: "I inform that the aforementioned [Tumanov Nikolai] was an employee of the WUBP in Warsaw [from 15 February 1952], and was dismissed from his position on 31 March 1953. Other incriminating materials about the aforementioned have been transmitted to the head of the Main Department of the WUBP”. Equally erroneous conclusions have been drawn by [judge Marian?] Osowski, who questioned the revolutionary involvement of the tsarist officer: "Allegedly, he operated in the underground with Czesław Skoniecki, current editor-in-chief of Chłopska Droga and Col. Jastrzębski, current head of the WUBP in Lublin; he is believed to be a recipient of the Partisan Cross. ${ }^{69}$

Indeed, the authorities of the Polish People's Republic have decorated him with the Partisan Cross. ${ }^{70}$ Nikolai Tumanov passed away on 17 October 1960, and is buried at the Powązki Military Cemetery (section: II B 28, row: 10, plot: 12), not far from one of his sons, i.e. the one that did not die in the massacre at the Ochota Hospital. ${ }^{71}$

na rzecz Wydz. II Dep. III MBP nr BD-036/3.I/51 nr 10999/2/51, 31.10.1951 [Information by Dept. II of MBP to Sect. II, Dept. III of MBP], fols. 22-23.

69 AIPN BU, 0-423/2603, Wojewódzki Urząd Bezpieczeństwa Państwowego, L. dz. PE-2486/53, 2.04.1953 [Provincial Office of Public Security], fols. 24-27; Dyrektor Departamentu III MBP, płk Andrzejewski do Naczelnika Wydziału III UBP, 24.03.1953 [Dir. of Dept. III of MBP, Col. Andrzejewski to Head of Dept. III of UBP (Office of Public Security)], fol. 29; V-Dyrektor Departamentu X MBP, ppłk Światło do Dyrektora Departamentu III MBP, płk Czaplickiego, 19.03.1953 [Dep. Dir. of Dept X of MBP, Lt.-Col. Światło to Dir. of Dept. III of MBP, Col. Czaplicki], fol. 30.

70 The Partisan Cross was established on 26 October 1945 by decree of the Council of Ministers of the Provisional Government of National Unity, approved by the Presidium of the State National Council. The Polish communists established this decoration "to commemorate the heroism of partisan troops in their armed struggle against the Hitlerite [sic! German] occupiers for Independence, Freedom and Democracy, and to reward their combat accomplishments". In the hierarchy of decorations of the Polish People's Republic, the Partisan Cross ranked one spot below the Cross of Valour.

71 AIPN BU, 0-423/2603, Raport o zarejestrowaniu w ewidencji ogólno-informacyjnej do zastępcy naczelnika Wydz. II-go, kpt Branda, 12.05 .1955 [Report on reg. for dep. head of Dept. II, Capt. Brand], fol. 47; and http://www.cmentarzekomunalne.com.pl/mapa/mapa.php?cment=PWZ$\mathrm{KI} \& \mathrm{rzad}=10 \& \mathrm{kwatera}=\mathrm{II} \% 20 \mathrm{~B} \% 2028 \& \mathrm{grob}=12 \& \mathrm{dane}=+\mathrm{imie}=+$ nazwisko $=$ Tumanow + check nazwisko $=$ on + check_ur $=+$ rok $=1800+$ miesiac $=1+$ dzien $=1+$ rok $2=2015+$ miesiac $2=8+$ dzien $2=2+$ check_zg=+rok_zg1 $=1800+$ miesiac_zg1 $=1+$ dzien_zg1 $1=1+$ rok_zg2 $=2015+$ miesiac_zg2 $=8+$ dzien_ $\mathrm{zg} 2=2+$ cmentarz=\#kotwica (access: 17 January 2017). 


\section{Russians on Polish side during Warsaw Uprising}

This little-known aspect of the history of the Warsaw Uprising includes several individuals fighting on the insurgents' side or supporting them. The first two representatives of this group were the sons of Col. Tumanov (and Janina Tumanowa, née Gorliwa), who both died in the Uprising. The elder of the two was Włodzimierz (b. 17 November 1924, d. 11 August 1944). He was a soldier of the Home Army and fought as rifleman under the nom de guerre "Książę" (Prince), serving within the $4^{\text {th }}$ sub-district of the AK Warsaw District, although his actual assignment is unknown. ${ }^{72}$

This sub-district shielded the city from the south-west, bordering Mokotów, Sródmieście and Wola. The seizure of Ochota by the insurgents deprived the Germans of access to the shortest transport arteries, which led from the south-west and the south, through the city centre, to the bridges on the Vistula River. This hindered significantly the provision of supplies for the Ostheer [Eastern Army], then fighting against the Soviet $2^{\text {nd }}$ Armoured Army. The insurgents failed to capture the strongly fortified German barracks located in the dormitory at Narutowicza Square, in the building of the State Forest Directorate at 56 Wawelska Street, and at 8 Tarczyńska Street. The insurgent units of Col. "Grzymała" have both been outmanned and outgunned. At the time of the concentration, only $50-60 \%$ of troops had reported for duty in line platoons at designated points. The assaults on designated targets, which began on August $1^{\text {st }}$ at 5:00 p.m., collapsed rapidly as the attackers suffered heavy losses. Despite their motivation and bravery, the insurgents failed to seize any of the key facilities. Following these defeats, the commander gathered the decimated troops in the quadrangle of the streets Asnyka, Niemcewicza, Grójecka and Filtrowa, where he mounted the defences. After staff briefing, Lt.-Col. Sokołowski ordered the evacuation of surviving fighters to the woods around Chojnów and Sękocin, hoping to rearm them and bring them back into combat.

On the night of August $1^{\text {st }} / 2^{\text {nd }}$, from before the tenement in $7 / 9$ Niemcewicza Street, a column of over 500 people marched out under cover - 50 of whom were

72 Sub-District IV (Ochota) of the Home Army - codenames: "Osiemnastka", "18” (in the SZP), and later in the ZWZ/AK "44", "XXIV" (since 15 June 1944), "IV” (since 9 August 1944) organisational body of the Warsaw District of the Home Army operating during the German occupation of Poland. At the outbreak of the uprising, the district consisted of around 15001800 soldiers and officers. It also included the Women's Military Service, comprising around 400 female conspirators in the sanitary and communications departments. The commander of Sub-District IV (Ochota) was Lt.-Col. Mieczysław Kazimierz Sokołowski, noms de guerre "Grzymała", "Ojciec", "Pomian", "Unikat". The units remaining in the Ochota district adopted a defensive role, forming two redoubts: "Wawelska": in the quadrangle of blocks along the streets Wawelska, Pługa, Mianowskiego and Uniwersytecka, commanded by 2nd-Lt. Jerzy Gołembiewski ("Stach"); and "Kaliska": in the tobacco factory complex (Monopol Tytoniowy) and adjacent houses, commanded by Lt. Andrzej Chyczewski ("Gustaw"). 
well-armed, but the rest were defenceless. They suffered heavy losses near Pęcice. Three units stayed back in Ochota, having not obtained the message about the concentration and evacuation. Among them was Rfn. Vlodzimierz Tumanov, most probably serving at that time in the platoon of 2nd-Lt. Jerzy Gołembiewski (“Stach").

These insurgents mounted the defences of the Wawelska redoubt, formed by: the Hall of the Cooperative of Engineers of the former Ministry of Railways (62 Wawelska Street, corner of 15 Mianowskiego and Pługa Streets) and Hall of the Cooperative of Employees of the Ministry of Railways (60 Wawelska Street, at the intersection of 1 Uniwersytecka and 13 Mianowskiego Streets). After the fall of the neighbouring Kaliska redoubt (quadrangle between the streets Kopińska, Białobrzeska, Joteyki, and Kaliska), this second insurgent bastion was successfully defended by the platoon of 2nd-Lt. "Stach" for almost a week. The Home Army managed to eliminate temporarily one of the German Jagdpanzer $38(t)$ Hetzer tank destroyers from the Armee Panzerjäger Abteilung 743 that were supporting the SS-RONA assault regiment. During these clashes, on August 6, Włodzimierz Tumanow was gravely wounded while defending a building on Wawelska Street. The Russian insurgent was transferred to the hospital located in a cellar in 15 Mianowskiego Street.

Meanwhile, the Russians from RONA launched a final assault on August $11^{\text {th }}$, which forced the defenders to evacuate through the canals (more than 80 of them reached Sródmieście and joined the "Golski" AK Battalion). 14 orderlies and 3 doctors remained on duty, taking care of 20 seriously wounded insurgents. Despite a white flag having been raised, the buildings were still under gunfire. At nightfall, RONA soldiers entered Wawelska Street, killing more than 80 people in this area (wounded insurgents and residents of the building suspected of taking part in combat). The list of victims included Rev. Jan Salamucha (chaplain of the "Ochota" AK District) and Col. Tumanov's son, Vladimir/Vlodzimierz. ${ }^{73}$

Here is a testimony of the chronicler of uprising in Ochota:

It was already 7 p.m. when the SS company [SS RONA soldiers] has surrounded the buildings of the Academy of Political Sciences in Wawelska Street. It took them quite a long time to enter the buildings, which were covered with rubble up to the first floor. This only exacerbated their fury. Eventually, they smashed the window over the staircase door from Pługa Street. Having dug through the dirt used to fortify the door, they burst inside; in rushed a bunch of butchers and robbers [soldiers] from the RONA regiment,

${ }^{73}$ M. Motyl, S. Rutkowski, Rejestr miejsc i faktów zbrodni popelnionych przez okupanta hitlerowskiego. Powstanie Warszawskie 1 VIII - 2 X 1944, Warszawa, 1994, p. 92 (15 Mianowskiego Street: mention of 9 wounded insurgents murdered by Russians from SS-RONA), pp. 170-171 (60 Wawelska Street: eighty casualties, including Włodzimierz Tumanow "Książę" murdered also by Russians); Д. Жуков, И. Ковтун, 29-я гренадерская дивизия СС “Каминский”, Москва, 2009, pp. 172-175; and http://www.1944.pl/historia/powstancze-biogramy/Wlodzimierz Tumanow (access: 17 January 2017) 
followed by a German officer. [...] They also barged into the cellar where the hospital was located, and murdered all our wounded there, including Erazm Maciejewski, Jan Łempicki, Jarosław Skrzyński, and two teenage boys who had been wounded in the same explosion, i.e. Włodzimierz Tumanow and Janusz Kwiatkowski; the agonising, half-conscious "Lew" was killed lying on a stretcher. And finally, they grabbed some wood and papers and then set fire to the hospital with all the corpses within. ${ }^{74}$

The Rifleman "Książę" is commemorated at the Warsaw Uprising Museum by a brick in the Memorial Wall: column 135, position $63 .^{75}$

His brother Eugeniusz (b. 9 August or 31 December 1926, d. 18 September 1944), fought in the rank of rifleman as "Tur". He was assigned to SubDistrict III Wola of the AK Warsaw District, and served in the defence unit of the Commander of Sub-District III, i.e. the $300^{\text {th }}$ Defence Platoon (heretofore $16^{\text {th }}$ Diversionary Detachment) under the command of Inf. Res. Lt.-Col. Stefan Mrozowski ("Pik"). Wounded on August $4^{\text {th }}$, he was replaced by Cadet plutonowy (Corporal)/2nd-Lt. Janusz Przedborski ("Ludwik"). ${ }^{76}$

After several days of combat in the Wola district, the $300^{\text {th }}$ Platoon retreated to the Old Town, and fought along the "Północ" group. After the fall of that district, Eugeniusz Tumanow used the sewers to reach Żoliborz with his original unit. There, he fought in the $208^{\text {th }}$ Platoon, “Żaba” company, "Żaglowiec” group commanded by 2nd-Lt. Edward Bonarowski ("Ostromir") numbering about 100 soldiers (as of September $15^{\text {th }}$ ). The younger of the Tumanow brothers befriended Jerzy Moździński ("Boruta”) from Żoliborz while serving with him in a youth detachment. $^{77}$

${ }^{74}$ J.K. Wroniszewski, Ochota - Okęcie. Przewodnik historyczny po miejscach walk i pamięci z lat 1939-1944, Warszawa, 2002, pp. 111-112.

75 A research into the website of the Warsaw municipal cemeteries, and more precisely Powązki Military Cemetery, revealed that Nikolai Tumanov had three sons, including the eldest Jerzy, who was born on 2 September 1922 and died on 25 July 1979. Beside him was buried Włodek Tumanow (1956-2003), most probably Jerzy's son, who died in Stockholm; see: http://www. cmentarzekomunalne.com.pl/mapa/mapa.php? cment=PWZKI\&rzad=11\&kwatera $=\mathrm{A} \% 20$ $27 \&$ grob $=27 \&$ dane $=+$ imie $=+$ nazwisko $=$ Tumanow + check_nazwisko $=$ on + check_ $\mathrm{ur}=+$ rok $=1800+$ miesiac $=1+\mathrm{dzien}=1+$ rok $2=2015+$ miesiac $2=8+$ dzien $2=2+$ check_zg $=+$ rok_ zg1=1800+miesiac_zg1=1+dzien_zg1=1+rok_zg2=2015+miesiac_zg2=8+dzien_zg2=2+cmentarz=\#kotwica (access: 17 January 2017).

76 Sub-District III (Wola) of Home Army Warsaw District - codenames: "Szesnastka", "16" (in the SZP), and later in the ZWZ/AK "43", "XXIII" (since 15 June 1944), "III" (since 9 August 1944) - organisational body of the Warsaw District of the Home Army operating during the German occupation of Poland in a large part of the Wola district. The military units of this sub-district took part in the Warsaw Uprising. The commander of the sub-district was, since April 1943, Lt.-Col. Jan Tarnowski ("Lelek", "Waligóra")

77 E. Bonarowski "Ostromir”, Burza nad Dworcem Gdańskim. W bój bez broni, Warszawa-Kraków, 2014, pp. 174 and 178 ("Mr. Edward, please take care of... Please look after Jerzy as if he were your younger brother, I am begging you. Keep him close to yourself. He is so young, so unpredictable. Keep him close to yourself. From now on, 'Boruta' will be with me for 60 days." 
Here is how the death of the Russian soldier was remembered by his colleagues from his insurgent bastion, the building of the Prince Józef Poniatowski State Liceum and Gimnazjum (no. 5), also known as "Poniatówka", at 16 Lis-Kula Street:

Our first loss occurred only in the first decade of September, but a one-of-a-kind. During the last, morning round of inspection of the positions, Cpl. "Fab" [Fabian Rafalski] barely struggled through the debris of the demolished front staircase, to reach the landing where Rfn. "Tur" was on duty. He found him lying in such a position that his broken spine was supported by a vertical bar of the stair railing, his head on the upper floor steps, and his legs on the lower ones. No other injuries otherwise, not even traces of blood. The blast of the shell deprived him of life. "Tur" was the first dent in the ranks of the youth detachment. He was interred on the grounds of the "Poniatówka". (I am not sure whether "Tur" or Maculewicz was the first casualty).

The partisans made him a coffin in the carpentry workshop in the courtyard; Cpl. Dziemianko ("Janek"), de facto commander of the group, then washed his face, as "it would be unacceptable that a soldier depart into afterlife dirty", took out his papers and partisan pass from his pocket, and inserted them along with a makeshift "death certificate" in a beer bottle with a rubber clamp. The bottle was then placed the coffin near the deceased's left leg. Nothing should be placed along the right side of a soldier's body, as when the deceased will report his arrival "there", he ought to perform a salute; his right hand must therefore be free. Dziemianko has had already prepared many soldiers this way for their afterlife while fighting in the Woods, and so he would pursue this tradition until the end of September. The coffin was then brought to the school common room converted into a chapel. In this chapel, the chaplain [Capt.] Rev. Stefan Sydry of the $21^{\text {st }}$ Infantry Regiment celebrated a quiet Mass every Sunday. Now, Rev. Sydry, dressed in a black chasuble, was holding a mourning mass and colleagues looked at the open coffin in silence, then sealed it and carried it to the edge of the playground where the grave had been dug. ${ }^{78}$

Eugeniusz Tumanow (“Tur”), died on 18 September 1944. Hanna Moździńska, the mother of his friend Jerzy, identified the graves of both in July 1945. She organised their exhumation on her own, and had them interred at the Powązki Military Cemetery. Eugeniusz Tumanow was buried in the same grave (section A 27, row 11, plot 27) as his brother Jerzy, and his nephew Włodzimierz (Włodek). Their relatives only discovered their grave in the 1950s. "Tur" is commemorated at the Warsaw Uprising Museum by a brick in the Memorial Wall: column 135, position $62 .{ }^{79}$

\footnotetext{
"Pożegnanie z matką syna odchodzącego na wojnę", ibid., p. 31); Z. Puchalski, "Walki powstańcze na Woli (1-11 VIII 1944)”, Rocznik Warszawski, 10 (1971), eds. B. Grochulska, S. Herbst, J. Kazimierski, p. 215; and http://www.1944.pl/historia/powstancze-biogramy/Wlodzimierz_ Tumanow (access: 17 January 2017).

78 Bonarowski, Burza nad Dworcem Gdańskim, pp. 192-193.

79 http://www.1944.pl/historia/powstancze-biogramy/E_Tumanow (access: 17 January 2017); http:// www.cmentarzekomunalne.com.pl/mapa/mapa.php?cment=PWZKI\&rzad=11\&kwatera $=\mathrm{A} \% 20$ $27 \&$ grob $=27 \&$ dane $=+$ imie $=+$ nazwisko $=$ Tumanow + check_nazwisko $=$ on + check_ur $=+$ rok $=$ $1800+$ miesiac $=1+$ dzien $=1+$ rok2 $=2015+$ miesiac $2=8+$ dzien $2=2+$ check_zg $=+$ rok_zg $1=1800+$ mie -
} 
Nikolai's third son, Jerzy, is mentioned in a note by the inspector of District IV, 2nd-Lt. Wiesław Gawor, also case officer of secret collaborator (Tajny Wspótpracownik, TW) Bernard, i.e. the grandson of Nikolai Tumanov, Włodek (b. 10 September 1956 in Warsaw, d. 2003 in Stockholm):

His father, Tumanow Jerzy, passed away in 1979. In 1939, he joined the ZWZ, and was arrested the very same year by the [G]estapo. Following incarceration at Szucha Avenue and the Pawiak Prison, he was sent to Oświęcim [KZL Auschwitz], then to [KZL] Gross-Rozen [Rosen] and [KZL] Oranienburg, from where he fled in February 1945. Since 1946, he had been a member of the ORMO and belonged to the PPR. In 1948, he was sentenced to 25 years in prison, of which he served 5 and a half. After his release, he was rehabilitated, and found work in the hospitality sector as a supplier. He was a member of the Society of Fighters for Freedom and Democracy (ZBOWiD), and has been on veterans' compensation since $1978 .^{80}$

Aleksandr Panin, the Orthodox clergyman and theology scholar mentioned earlier, also perished due to the Uprising. The 38-year-old Russian was murdered by the Germans on 1 August 1944 behind the Orthodox church at 2 Cyryla i Metodego Street, together with 17 other men (Russians, Belarusians, Ukrainians and Poles). ${ }^{81}$

There were also Russian women who could serve as role exemplars for Poles, usually serving in the Uprising's (AK) sanitary services. Above all, Nadzieja Drucka O’Brien de Lacy [Russian: Nadezhda Drutskaya] (b. 17 January 1898 in Warsaw, d. 29 August 1986 in Warsaw). Her parents were Gen. Sergei Drutski, professor at the Military Academy of Law and descendent of the ducal house of Drutski, and Maria, née Safonowicz. The family left for St. Petersburg in 1902. Nadzieja completed the Institute for Noble Maidens, i.e. the Smolny Institute in 1914. After World War I, she moved with her family to Moscow. She completed medical courses there, and was sent as a Russian Red Cross nurse to the war front, where she made acquaintance with a Pole of Irish descent, Maurycy O’Brien de Lacy. They became engaged, then married in August 1918 in Moscow. They managed to relocate to Poland to his family estate in the village of Augustówka, where they would live until 1939.

Nadzieja Drucka O'Brien de Lacy was involved in charitable and literary activities. She became Vice-President of the local branch of the Polish Red Cross, Vice-President of the Association of Female Landowners and President of the

siac_zg1 $=1+$ dzien_zg1 $1=1+$ rok_zg2 $=2015+$ miesiac_zg2 $=8+$ dzien_zg2 $=2+$ cmentarz=\#kotwica (access: 17 January 2017); and http://nieobecni.com.pl/index.php?s=grob\&id=144277 (access: 17 January 2017)

${ }^{80}$ AIPN BU, 00 1121/4399, Notatka służbowa dot. studenta II roku Wydz. Filozofii Chrześcijańskiej Akademii Teologii Katolickiej, Włodzimierza Tumanowa; 20.03.1980 [Oper. note on Włodek Tumanow (TW Bernard)], fol. 25.

${ }^{81}$ Motyl, Rutkowski, Rejestr miejsc i faktów, pp. 28-29. 
Eliza Orzeszkowa Association of Literature and Art Lovers in Grodno. Famous writers flocked to Grodno at her invitation, such as Maria Dąbrowska, Zofia Nałkowska, Julian Tuwim, Jan Parandowski, Juliusz Kaden-Bandrowski, and Stanisław Witkiewicz. On 23 October 1929, Zofia Nałkowska wrote in her diary (published as Dzienniki): "I have spent these four days in Augustówek as a guest of the O'Brien de Lacys as a result of their repeated invitations; never would I have imagined that I would feel there so well. The sunny autumn, the red and yellow leaves behind the window, the charm of the local nature. The escapades with Mr. O'Brien de Lacy as our driver; such an amiable, thoughtful and gentle person". Nadzieja Drucka O’Brien de Lacy joined the Polish Pen-Club in 1930. Every year, her husband and herself organised summer camps for the poorer inhabitants of Grodno. She maintained contacts with representatives of Russian emigrants in Poland. ${ }^{82}$ At the outbreak of World War II, her husband remained in Grodno, taking part in the defence of the city, while she and her daughters Gabriela and Irena found shelter in Spusza, estate of the Sapieha; they later reunited in Lithuania. The family stayed in Liberyszki, the estate of Benedykt Karp, a friend of Maurycy from his youth.

In 1941, they cross the border of the General Government illegally, and survived the occupation in Warsaw. Nadzieja taught foreign languages, and participated in underground education. As she recalled: "There was the underground education, but also official vocational schools, which too offered illegal courses such as history, geography and Polish literature. Gaja went to the commercial school in Nowogrodzka Street. Irena began to work as a waitress at some club. Some Russian and Georgian friends suggested that I sign up to the Russian Committee, which would protect me from round-ups and grant me several privileges". ${ }^{3}$

Nadzieja Drucka also revealed several details about underground education:

Warsaw was initially divided into five areas, then thirteen. Each area was administered by a board consisting of three people, which oversaw matters of secret teaching and mutual support, as well as civil and military struggle. One area included on average ten schools; in each of these, the teachers selected from their milieu a liaison between the school and the board. [...] The curricula were uniform, based on pre-war programmes with small deviations towards democratisation. Despite growing terror, an unyielding atmosphere of patriotism prevailed. Underground education, so far only at primary level, was soon extended with secondary level curricula, spontaneously and rapidly growing in popularity; the Secret Teaching Organisation [Tajna Organizacja Nauczycielska, TON] and other conspiratorial educational entities also contributed to the cause, effectively setting out the principles that this teaching should follow. ${ }^{84}$

82 Z. Nałkowska, Dzienniki, vol. 3: 1918-1929, Warszawa, 1980, pp. 180-181; J. Sypuła-Gliwa, “Dzikie gęsi z Zielonej Wyspy", Echa Polesia, 4 (2008), no. 20, p. 69.

${ }^{83}$ N. Drucka, Trzy czwarte... Wspomnienia, Łomianki, 2011, p. 140.

${ }^{84}$ N. Drucka, Szkoła w podziemiu. Z dziejów polskiego tajnego nauczania $w$ latach okupacji hitlerowskiej, Warszawa, 1973, pp. 49-50. 
Elsewhere, Drucka noted: "In the last few years, the number of primary school students in Warsaw alone amounted to 68,000, of which 12,000 were covered by underground education in terms of 'native' subjects in classes V-VII, as well as classes I-II of gimnazjum. As for secondary school, about 24,000 young people still in Warsaw alone - benefited from secret teaching at that time" ${ }^{85}$

Also fascinating were the observations of a wife and mother about the transformations occurring in her family living in Warsaw under the German occupation. The duchess wrote in her memoirs:

I already knew that Maurycy belonged to a secret organisation, although would not speak about it, and soon I myself, with the support of Lieutenant Paweł Kaden-Bandrowski, joined the Red Cross Sanitary Control of the Home Army, all while hiding this fact from my husband and children. [...] I speculated that my older daughter, Irena, who was already working at a cosmetic company, belonged to some organisation, as she used to disappear in the afternoon and return five minutes after the curfew, filling me with dread. I would ask no questions - neither her, nor my husband. In some strange fashion, discreetness was respected even within the family; whether for safety reasons, or simply by ordinary politeness. It was not until just a few months before the uprising that we "revealed ourselves", no longer hiding what we had been doing for several years. ${ }^{86}$

During the Warsaw Uprising, Nadzieja Drucka served under the nom de guerre "Literat" in the organisation Pomoc Żolnierzowi ${ }^{87}$ and at the Sanitary Control of the Home Army's District of Warsaw.

Unable to reach my position near Narutowicza Square, I reported for duty in Powiśle (the southern part of which is referred to in literature as Czerniaków) to the headquarters of Group V, where I encountered three people I knew from the pre-war era: Captain "Kryska" [Zygmunt Netzer], Lieutenant "Siekiera" [Roman Rożałowski] and Lieutenant "Jeleń", a school inspector from Grodno. My husband went to work as usual. [...] Gaja and I grabbed wound dressings and headed for the Group's staff, located in the intersection of Wilanowska and Okrąg Streets. [...] Gaja, being unqualified, was appointed auxiliary. It was horrifying when she accompanied two or three men with baskets to bring food from

${ }^{85}$ Ibid., p. 60; and http://www.1944.pl/historia/powstancze-biogramy/Nadzieja_OBrien_De_Lacy (access: 17/01/2017).

86 The following words highlight the sophistication of this remarkable person: "I have always believed that the woman's role in the world is not to kill, but to give life and to alleviate suffering. A long time ago, back when we lived in Russia, my father's newspaper published my article, in which I spoke out against the idea of female battalions."; see: Drucka, Trzy czwarte, pp. 141 and 147.

87 Pomoc Żotnierzowi (PŻ, "Help to Soldiers"): a women's organisation founded in March 1942 initially as a section, and then an independent sub-department within the structures of the Bureau of Information and Propaganda of the AK Headquarters. The PŻ cooperated closely with the Military Women's Service (Wojskowa Stużba Kobiet, WSK). The purpose of this organisation was to provide care to Home Army soldiers. Its members were colloquially called "peżetki" (from the abbreviation). 
Społem [Polish consumer cooperative], and the Germans, having discovered that spot, would begin to bombard the entire area. ${ }^{88}$

During the Warsaw Uprising, she was a nurse at the Field Hospital no. 3 of the "Kryska" Group at 2/4 Okrąg Street (from August 8 to September 19), then at 18/20 Wilanowska Street, and then 1, 3, 5 Wilanowska Street (from September 19 to 23) in Upper Czerniaków district. The hospital's commander, Irena Semadeni-Konopacka, described the final days of her service during the Uprising in the following words: "One by one, I was approached by all the people with whom I had been working for the last two months; they would say farewell, then leave more or less willingly. [...] I would still hear lots of gunshots, and I suppose they were executing the people standing in the yard" ${ }^{99}$ Alongside Nadzieja Drucka worked her 25-year-old daughter, Irena. She participated in the Warsaw Uprising as a peżetka under the nickname "Gaja". ${ }^{90}$ Their relative, Margaret O'Brien, ended up in the Ochota district, in a house in Spiska Street, which became a place of accommodation for RONA soldiers:

Several "Vlasovites" [soldiers of the SS-RONA regiment] were roaming in the yard, as they used it to reach their usual path: from the railway station area to Grójecka Street. They paraded back and forth through our gate. In the evening they would bring in some women [...] I did not want to see nor hear what was happening there. [...] Drunken "Vlasovites" were sleeping on the stairs, [Tomek] carefully walked past them and went down to the cellar. Passing through the gate was out of the question. The soldiers had laid stolen mattresses and duvets there, and were resting there. In the cellar, Tomek discovered a mass grave: partially burnt corpses lying in the passage. The cellar corridor was one massive grave. [...] it was in this house, in this cellar, that Ryszard Jahołkowski, my cousin and godfather, had died. A horrifying execution had taken place; they ordered people to stand on the stairs, and shot them in the back of their heads. They butchered all the residents of the building this way. ${ }^{91}$

After the war, Nadzieja Drucka stayed in Poland; from 1947 to 1949, she has worked at the Capital Reconstruction Bureau in Warsaw, then left to focus on her literary career. Decorated with the Knight's Cross of the Order of Polonia Restituta, she lived in Warsaw until she passed away on 29 August 1986. The Duchess is interred at the Orthodox cemetery in Warsaw. ${ }^{92}$

88 Drucka, Trzy czwarte, p. 151.

89 Archive of the Warsaw Uprising Museum (hereinafter: AMPW), V/73, Testimony of Irena Semadeni-Konopacka, Executions of civilians and AK soldiers in Warsaw, i.e. in Powiśle, no date, fols. 11, 12.

90 B. Urbanek, Pielegniarki i sanitariuszki w Powstaniu Warszawskim w 1944 r., Warszawa, 1988, pp. 252, 365, 369; http://www.1944.pl/historia/powstancze-biogramy/Nadzieja_OBrien_De_Lacy (access: 17 January 2017); http://www.1944.pl/historia/powstancze-biogramy/Irena_OBrien_De_ Lacy (access: 17 January 2017).

91 AMPW, P/5187, Testimony of Margaret O’Brien - Ochota, no date, fol. 3.

92 Wspótcześni polscy pisarze i badacze literatury. Słownik bibliograficzny, vol. 2, eds. J. Czachowska, A. Szałagan, Warszawa, 1994, pp. 209-211. 


\section{Russians from the Nowogródek and Wilno Voivodeships}

Several Polish citizens, born into the families of Russian post-revolutionary émigrés, were native of the Eastern Borderlands, which then constituted a real ethnic mosaic. Several of them turned out to be Polish patriots, revealing sincere military engagement. Their names would become enshrined in the history of the Home Army units from the Nowogródek and Wilno Voivodeships.

One lesser known figure was Walerian Tryfonow [Russian: Valerian Trifonov] ("Kostek"), ${ }^{93}$ who served as commander of the Horodyszcze [Belarusian: Haradzishcha] outpost in the Nowogródek AK District. He fought against German occupiers and Soviet partisans alike. The weakness of the Polish forces came into light at the outbreak of their conflict with the Soviet "People's Avengers". The clashes with the "allies of our allies" had been sparked by the pacification of village of Naliboki on 8 May 1943, followed by the massacre at the "reactionary" village of Koniuchy on 29 January 1944. Another act of aggression was the disarmament of the Polish Partisan Unit (POP) ordered by Panteleimon Ponomarenko on 14 November 1943. This decision caused Soviet-Polish hostilities, and contributed to the achievement of a Polish-German "ceasefire". The Home Army Headquarters in Warsaw criticised this agreement in the light of the "allies of our allies" principle, which in turn was met with bewilderment from the local perspective. In a situation of increasing conflict with the Soviet partisans, Sgt. Tryfonow undertook negotiations with the Germans, hoping that a ceasefire would reinforce the Polish partisans and lead to the liberation of AK conspirators and their families who were detained at the Koldichevo concentration camp (former Baranowicze County). ${ }^{94}$

The talks with the Germans ended badly, which might have been affected by the negative evaluation of earlier negotiations by rotmistrz (Rittmeister or riding master) Józef Świda ("Lech") and the command of the AK Niemen Land Group with local German authorities. In addition, the Germans could have been aware that Tryfonow had deserted in May 1943 from the Belarusian National Defence (Byelaruskaya Krayovaya Abarona, BKA). "Kostek" failed to secure the release of the Poles detained at KL Koldichevo and in Baranavichy. Meanwhile, the German police, assisted by a BKA battalion, carried out an operation under the Bandenbekämpfung doctrine, effectively dispersing a 40-strong, poorly armed "nucleus of a partisan unit in the Baranavichy area" in the village of Przewłoka/ Przewłuka (Pyarevalaka)

93 The scant information available would suggest that he had served earlier in the Polish Army as Reserve Corporal in the $16^{\text {th }}$ Land of Tarnów Infantry Regiment.

94 B. Chiari, "Kriegslist oder Bündnis mit dem Feind? Deutsch-polnische Kontakte 1943/44", in: Die polnische Heimatarmee. Geschichte und Mythos der Armia Krajowa seit dem Zweiten Weltkrieg, eds. B. Chiari, J. Kochanowski, München, 2003, p. 497; K. Krajewski, Na straconych posterunkach. Armia Krajowa na Kresach Wschodnich II Rzeczypospolitej 1939-1945, Kraków, 2015, p. 205; id., "Der Bezirk Nowogródek der Heimatarmee. Nationalitätenkonflikte und politische Verhältnisse 1939 bis 1945”, in: Die polnische Heimatarmee, pp. 580-582. 
near Horodyszcze. 16-20 AK soldiers perished in the clash, while the German and Belarusian police burned the village down, murdering its hundred inhabitants. The surviving conspirators retreated to the Naliboki Forest. Having found refuge, Tryfonow and his group 20 soldiers then initiated contact, on May 20, with the "Budyonny" Detachment of the Soviet "25 Years of the BSSR" Partisan Brigade. For a few days, Sgt. "Kostek" would remain commander of his unit, under supervision of Deputy Political Officer Makowski. The Soviet partisans, however, would not trust their collaborators from the Home Army; and so, merely one week later, Tryfonow, deputy commander Stanisław Rowiński, and chief-of-staff Kazimierz Olifierka have all been "executed for espionage", while their subordinates have joined the ranks of the Soviet partisan troops, later incorporated into the Red Army. ${ }^{95}$

The fates of the soldiers of the Home Army's $3^{\text {rd }}$ Battalion, $77^{\text {th }}$ Infantry Regiment - the Striking Cadre Battalions (UBK) - remain just as obscure. Rfn. Yakimov (Karol Jakimow) ("Lolek") served in the communications platoon, commanded by 2nd-Lt. Stefan Teodorowicz ("Stefan"). Yakimov participated in May 1944 in the capture of a Panhard truck near Lida. He died on 7 July 1944 during Operation "Ostra Brama" ["Gate of Dawn"], while fighting near the village of Góry. We know just as little about Lavrentev [Jan Ławrentiew] ("Felek"). The orderly Sofiya Lavrentev [Zofia Eawrentiew] ("Zoja") served in the same detachment. Earlier, when working as secretary at the kommandantur of the Todt Organisation (OT), she had been monitoring the actions of the German authorities, and helped a UBK patrol commanded by podchoraży Mieczysław Lipko ("Satyr") in the disarmament of the OT warehouse in Lida. Later, the Russian woman was hired as kitchen assistant at a stützpunkt in the Dworzyszcze estate, and was entrusted with reconnaissance in that location. The assault team selected among the soldiers of the $3^{\text {rd }}$ Battalion, $77^{\text {th }}$ Infantry Division of the Home Army then captured the strongpoint, seizing a large number of firearms and two vehicles. ${ }^{96}$

Another example of model Polish patriotism has been set by the Kurochkin (Kuroczkin) brothers. However, defining them as immigrants would not be entirely accurate. Mikołaj was born on 3 April 1914 as son of Aleksei and Stanisława (née Wyrzykowska), when the country was still under the rule of the Emperor Nicholas II. Then, as a result of World War I - which lasted in Eastern Europe until 1921 - Kurochkin, as a native of Wilno, became a Polish citizen and

95 Armia Krajowa w dokumentach 1939-1945, vol. 3: Kwiecień 1943 - Lipiec 1944, London, 1976, pp. 473-474; and Nowogródzki Okręg AK w dokumentach, comp. K. Krajewski, Warszawa, 2009, p. 50; Krajewski, Na straconych posterunkach, p. 224; Z. Boradyn, Niemen rzeka niezgody. Polsko-sowiecka wojna partyzancka na Nowogródczyźnie 1943-1944, Warszawa, 2013, p. 188-189.

${ }^{96}$ K. Krajewski, Uderzeniowe Bataliony Kadrowe 1942-1944, Warszawa, 1993, pp. 416, 421-422, 449-452, 466, 485. Additional oral information obtained from the author of the monograph proved that Sofiya Lavrentev had been incorporated into the "people's" (communist's) Polish Army, and committed suicide in 1945. 
member of the city's large Russian diaspora. At the age of 21, he underwent a oneyear military training at the elite $1^{\text {st }}$ Legions Infantry Regiment. He then undertook studies at the Stefan Batory University (USB) in Wilno/Vilno, which is probably where he met fellow student Lidiya Lvova, who will be mentioned later. Kurochkin belonged to the Academic Convent "Ruthenia Vilnensis", and was presumably also a member the Union of Russian Students of the Stefan Batory University (Soyuz russkikh studentov USB). ${ }^{97}$

The outbreak and the course of the war led by Germany and the Soviet Union against Poland temporarily placed Wilno/Vilno within the borders of Lithuania. The young Russian could therefore already undertake conspiratorial activities within the Wilno Independent District of the ZWZ, i.e. in opposition to the Lithuanians. He attached great importance to physical fitness. Kurochkin was an avid sportsman and aviation enthusiast. Presumably his tenyear-long practice in aviation allowed him to perform a flight on a human-powered aircraft on 12 May 1942, making him the first person to achieve such a feat on Polish soil. ${ }^{98}$

Kurochkin was admitted on 13 September 1943 to the "Bolesław I the Brave" Flying Unit and was sworn in as an AK soldier. "Personally, I only knew 'Leszczyna', and the Kurochkin brothers, known as 'Wiąz' and 'Leśny'. As I mentioned, we were armed poorly. We wore various civilian clothes; only 'Leśny' had an actual Polish military uniform", reminisced Marian Korejwo ("Milimetr"). In November, the two brothers and one more partisan "have been sent by the commander to Oszmiana [Belarusian: Ashmyany] with some mission. On their way, they encountered a Soviet partisan unit. They have been surrounded and disarmed. It was the same unit that we only recently conducted talks with. Luckily, they have been released, but their weapons were not returned", "Milimetr" recalled. A few days

97 Ruthenia Vilnensis was a corporation of the Russian ethnic minority. The organisation was supervised by University Senate member Prof. Sergiusz Schilling-Siengalewicz, and its seat was located at 5/4 Skopówka Street. The incomplete list of members includes, besides Kurochkin, two names: Dmitri Tverdohklebov (USB student of medicine from the Nowogródek area, who died tragically in what was probably the last fatal duel on Polish soil) and Marian Zdziechowski (b. 30 April 1861 in Nowosiółki, d. 5 October 1938 in Wilno), critic, historian of literature and culture, philosopher, professor of the Jagiellonian University, dean and rector of USB, professor honoris causa of the University of Tartu, member of the Polish Academy of Learning. He was an honorary member of the Ruthenia Vilnensis corporation. The members of the Russian corporation wore dark blue caps; see: AIPN GK, 919/2656, Ankieta personalna Mikołaja Kurochkina [Pers. survey of Mikołaj Kurochkin], fol. 1; P. Tomaszewski, Polskie korporacje akademickie w latach 1918-1939. Struktury, myśl polityczna, działalność, Toruń, 2011, pp. 459-460; Corporations Archive. Archive and Museum of Polish Students' Corporations [see: VIII. Akademicki Konwent "Ruthenia Vilnensis"] at http://www.archiwumkorporacyjne.pl/index.php/muzeumkorporacyjne/wilno/pozostale/ (access: 17 January 2017).

98 Konspiracja i opór społeczny w Polsce 1944-1956. Słownik Biograficzny, vol. 2, eds. T. Balbus et al., Kraków-Warszawa-Wrocław, 2004, pp. 186-187 (biography of Mikołaj Kurochkin by J. Kułak). 
before Christmas, "Wiąz" and "Leśny" voiced their support for Gracjan Fróg ("Szczerbiec"), in opposition to an attempt of relieving him as commander of the $3^{\text {rd }}$ Brigade AK. From January to June 1944, Mikołaj Kurochkin remained an active soldier and liaison of the $3^{\text {rd }}$ Brigade AK in Wilno/Vilno, where he lived in Krzywe Koło Street, close to the house inhabited by Fróg's wife, who was also a relative of his. ${ }^{99}$

In July 1944, he took part in Operation "Ostra Brama". After the seizure of Wilno/Vilno by the Soviets, Kurochkin, having successfully avoided getting uncovered, managed to obtain a job as a railway station officer at the Wilno/ Vilno Railway Station, where he was employed from July to December 1944 . He thus dodged conscription into the communist $1^{\text {st }}$ Polish Army of Gen. Berling. ${ }^{100}$

Kurochkin was then repatriated in December 1944 to Białystok as part of the activity of the Polish National Liberation Committee's (PKWN) delegation. Again, he managed to elude the UB filtration officers and relocate to nearby Hajnówka, where he found work at the District Directorate of the State Forests. Shortly thereafter, in February 1945, he was transferred to the $2^{\text {nd }}$ Platoon, $4^{\text {th }}$ Company, Independent Battalion of the State Forest Protection Forces, subordinated to the Supreme Directorate of State Forests. He assumed the position of deputy commander of this detachment (his superior being earlier officer Romuald Rajs, operating under the fake name of 2nd-Lt. Jerzy Góral ${ }^{101}$ ). The Białowieża Forest was where "Leśny" encountered the troops of Zygmunt Szendzielarz, as he was patrolling the forest with his unit. After some negotiations, the partisans released them and returned their weapons. Kurochkin obtained contact information for commander of the Home Army/Citizens' Home Army (AK/AKO) Hajnówka district Tadeusz Siedlecki ("Tadeusz") and Jadwiga Laskowska. ${ }^{102}$ "I remember that our first encounter took place in the lobby of the sawmill's administrative office [in Hajnówka]. The corridor was crowded, and among those people were "Bury" and "Kolka" [Mikołaj Kurochkin]. [...] They were talking to "Słoń". It felt as if they already knew each other", affirmed a witness of this encounter, Uhlan liaison officer Rajmund Drozd ("Mikrus"). ${ }^{103}$

It was at that time that the "interested parties" established the details of the meeting between Rajs and Szendzielarz, which took place before April $5^{\text {th }}$, during

${ }_{99}$ M. Korejwo, Moje ścieżki partyzanckie. W 3. Wileńskiej Brygadzie Armii Krajowej "Szczerbca", Warszawa-Kraków, 2014, pp. 22, 62, 159.

100 O. Christa, U "Szczerbca" $i$ "Łupaszki”, Warszawa, 2000, p. 141; J. Kułak, Rozstrzelany oddział. Monografia 3 Wileńskiej Brygady NZW Białostocczyzna 1945-1946, Białystok, 2007, pp. 58-59; P. Niwiński, Okręg Wileński AK w latach 1944-1948, Warszawa-Kraków, 2014, pp. 92-95; and L. Tomaszewski, Wileńszczyzna lat wojny i okupacji 1939-1945, Warszawa, 2010, pp. 524-534.

101 The reason for Romuald Rajs's demotion by one rank remains unknown; it can be assumed that the communist authorities were given false information.

102 Christa, U "Szczerbca" i "Eupaszki", p. 132; Kułak, Rozstrzelany oddział, pp. 91-92.

103 Kułak, Rozstrzelany oddział, pp. 98-99 (fragment of testimony of Rajmund Drozd “Mikrus”). 
Easter. Kurochkin was soon assigned to Liten (Lilen?) ${ }^{104}$, where he received command of a platoon of the state forest protection forces, but this information is not fully confirmed. After three months, the Russian deserted with his entire platoon, and reported on 10 May 1945 to the command of the $5^{\text {th }}$ Wilno AK Brigade of Major Zygmunt Szendzielarz ("Lupaszka"). The operation was coordinated by "Bury", Kurochkin's former superior; for that purpose, "Leśny" reported that his 30 -strong platoon would be heading in a different direction, i.e. towards the forest districts of Brańsk, Rudka and Pietrowo. ${ }^{105}$

After the end of World War II, the then 31-year-old did not decide to reveal himself or legalise his clandestine residence in Poland ruled by the PKWN (and later by the Provisional Government of National Unity [Tymczasowy Rzad Jedności Narodowej, TRJN]). The brigade, and consequently the II squadron expanded quickly, reaching a number of 300 soldiers; their duties included the elimination of active Polish communists from the PPR, as well as UB and MO officers and individuals suspected of cooperation with the NKVD and UB. Only two days after their merger with the $5^{\text {th }}$ Brigade, Rajs's and Kurochkin's sub-unit was sent on May $12^{\text {th }}$ on their first mission, where "the newcomers from the Forest Protection Forces set up an ambush on the road south of Dziatkowice. They engaged into combat with a Sov[iet] vehicle, killing three soldiers (a fourth one died from wounds in the forest), and seized a radio trans[mitter]-receiver, then handed over to "Korycki" [Capt. Jan Trusiak, commander of the Bielsk Podlaski District]". The squadron also conducted training activities, carried out a raid (with the entire brigade) to the south bank of the Bug, disarmed officers of the Militia, or even executed them as in Hołowczyce, confiscated goods and prepared expropriation money from warehouses and offices, always distributing some among the local population. Moreover, Kurochkin and Jurasow took part in the attack on the column of cars and trucks carrying soldier and officers of the Military Prosecutor Office of the Soviet $5^{\text {th }}$ Armoured Army and their spoils of war from Germany; the captured officers and soldiers were executed on 7 July 1945 in the village of Brzeziny (Podlasie region) by the $1^{\text {st }}$ and $2^{\text {nd }}$ squadron of the $5^{\text {th }}$ Brigade. On 16 September 1945, Sgt. Kurochkin was appointed deputy commander of the newly created NZW $3^{\text {rd }}$ Wilno Brigade headed by 2nd-Lt. Rajs. Just two weeks later, on 30 September 1945, "Leśny" was transferred to the position of commander

104 Most probably Lilienfeld, also known as Lelice.

105 During the last official trip to Białystok, "Bury" and "Leśny" accidentally met Cpl. Kazimierz Chmielowski ("Rekin"), who had returned to Białystok two days earlier following a brave escape from the camp in Kaluga. As Chmielowski was walking down the street with Aleksander Domalewski ("Ryży"), Kurochkin forcibly pulled him into a truck, to the shock of his colleague. Two specialists in the subject of pro-independence partisan forces incorrectly suggested that the subordination of 2nd-Lt. Rajs to Maj. Szendzielarz had already taken place during the concentration on 5 April 1945; see: K. Krajewski, T. Łabuszewski, Białostocki Okręg AK-AKO. VII 1944 - VIII 1945, Warszawa, 1997, p. 256; Kułak, Rozstrzelany oddział, pp. 102-103. 
of the NZW Łomża County ("Łaba"); from September to December 1945, he was a soldier of the National Military Union. ${ }^{106}$

Soon, i.e. at the end of 1945, Kurochkin was given permission to legalise his life outside of the NZW Białystok District; a request he had motivated by his desire to undertake studies. The Russian arrived in early October 1945 to Warsaw, where he made contact with Maj. Marian Kamiński, nom de guerre "Rawicz" (command of the NZW District I Warsaw). Less than a month later, "Leśny" was arrested with his commander Romuald Rajs at the conspiratorial office of the NZW in Warsaw located in Srodkowa Street. However, the conspirators have not been identified by the UB officer, and were soon released. Kurochkin later undertook an unsuccessful attempt to enter the Cracow University of Technology, then returned to Warsaw in mid-November. The command of NZW District I Warsaw put him in touch with Capt. Jan Morawiec ("Henryk", "Remisz"), head of the Special Action Emergency of the National Military Union (Pogotowie Akcji Specjalnej, PAS). The latter sent "Leśny" in mid-December to Katowice to assume command of an elite division of the PAS that would constitute the core of the then-recreated NZW District VIII Upper Silesia-Zagłębie (codename "Traugutt"). "Leśny" (soon to be known as "Polus") began to fulfil his duty in mid-December 1945; his contact point has been established in Warsaw at 74/10 Wołoska Street. Kurochkin was given modest financial support, as well written instructions with the PAS organisational chart, promotion proposal forms, etc. He began by establishing initial contacts in the area, but after a certain period of waiting in vain for Capt. Morawiec to show up at the conspiratorial office in Katowice, he decided to abstain from any further activity (although the PAS leader never mentioned anything about Kurochkin being dismissed from his duties, and maintained contact with him until March 1946).

By the end of the year, he left for Wrocław, wishing to start a new life, notably by undertaking studies at the Faculty of Chemistry of the Wrocław University of Technology. While in Lower Silesia, Kurochkin recruited Lt. Stefan Jabłoński ("Vis") - whom he had made acquaintance of in Warsaw - and appointed him as his informal substitute. In January 1946, the two NZW soldiers made several trips in order to locate "Remisz": to Warsaw, to Łódź, and then back to the capital again. Eventually, Kurochkin officially recommended Lt. Jabłoński as his successor,

106 AIPN BU, 1820/2, Ministerstwo Sprawiedliwości, Centralny Zarząd Zakładów Karnych, Lista osób zmarłych w więzieniach polskich w latach 1944-1956, part 1, vol. 2, Więzienia karno-śledcze, Warszawa, III 1993 [Ministry of Justice, Central Directorate of Correctional Facilities, List of individuals having died in Polish prisons in the years 1944-1956, part 1, vol. 2, Remand/ correctional prisons], fol. 134 (Mikołaj Kurochkin, s. Aleksego); AIPN GK, 919/2656, Wyrok w imieniu Rzeczpospolitej Polskiej dnia 1 grudnia 1946 [Judgement in the name of the Republic of Poland dated 1 December 1946 in case against Mikołaj Kurochkin], fols. 20-21, 26; M. Bechta, W.J. Muszyński, Przeciwko Pax Sovietica. Narodowe Zjednoczenie Wojskowe i struktury polityczne ruchu narodowego wobec reżimu komunistycznego 1944-1956, Warszawa, 2017, pp. 263-264; Krajewski, Łabuszewski, Białostocki, pp. 270-271; and S. Poleszak, Podziemie antykomunistyczne w łomżyńskiem i grajewskiem (1944-1957), Warszawa, 2004, p. 249. 
an idea he justified by his desire to pursue studies. "Polus" and "Vis" reported in January or early February 1946 to the organisational briefing of PAS officers, which took place in Łódź in Główna Street. Despite initial disagreement, no change was made in the position of commander of the Silesian District. However, "Remisz" ultimately approved Kurochkin's resignation, under the condition that the latter would remain at the disposal of the NZW.

The UB first arrested Kurochkin already in March 1946, when he was identified as one of the leaders of a student protest in the dormitory. The loud dissatisfaction he expressed in response to the unannounced switching-off of lights, which prevented students from studying during the end-of-term examinations, contributed to his arrest and interrogation. After agreeing to cooperate with the WUBP in Wrocław, Kurochkin was eventually released, but this prompted him to flee abroad. Lieutenant Lechosław Roszkowski ("Tomasz") directed "Polus" to the contact point of the command of the NZW Marine District in Gdynia. Kurochkin reached the coast in late March. He awaited two long months to be smuggled abroad, which never happened. The Russian "Cursed Soldier" was arrested on 11 May 1946 in Gdańsk, and executed on 19 February 1947 (another version states: 18 February 1947) in the prison in Rakowiecka Street in Warsaw. The place of his burial remains unknown. ${ }^{107}$

We know much less about the second of the Kurochkin brothers, Anatol. Before the war, he was a member of the Wilno Rowing Society. A straight route led from there to conspiratorial activity: Anatol Kurochkin formed a conspiratorial group with Witold Mikulicz-Radecki ("Swing”), Wiktor Romanowski ("Mister"), Marian Korejwo ("Jawor", at least at that time) and helmsman Henryk Rochlicki ("Leszczyna"). Then, in September 1943, his brother and himself were admitted to the "King Boleslaw the Brave" Flying Unit. His nom de guerre was "Wiąz". The older brother Kurochkin used a $7.62 \mathrm{~mm}$ Nagant M1895 Revolver, a 95 Nagant variant. ${ }^{108}$

Anatol, together with his brother Mikołaj and other Polish partisans, were part of the group which revolted by taking the side of their commander Capt. Gracjan Fróg ("Szczerbiec"). Since January 1944, Anatol and Mikołaj Kurochkin remained active soldiers of the Home Army $3^{\text {rd }}$ Wilno Brigade. ${ }^{109}$

The memoirs of Olgierd Christa allow us to make some assumptions about Mikołaj's conspiratorial activity based on the description of that of his brother's:

107 AIPN BU, 944/109, Akta sprawy przeciwko Michałowi Galejowi i in., Protokół przesłuchania podejrzanego Mikołaja Kurochkina, 14.08.1946 r. [Case file against Michał Galej et al., Report of interrogation of suspect Mikołaj Kurochkin], fols. 170-174; Protokół przesłuchania podejrzanego Mikołaja Kurochkina; 21.08. 1946 r., fols. 186-189v; AIPN BU, 944/110, Akta sprawy przeciwko Michałowi Galejowi i in. Protokół przesłuchania świadka Jana Morawca, 14.08.1946 r., fols. 154-156.

108 Korejwo, Moje ścieżki partyzanckie, pp. 19-20.

109 Christa, U "Szczerbca" $i$ "Еupaszki", pp. 52-53. 
An external expositure of the brigade operated in Wilno/Vilno [Lithuanian: Vilnius] under the leadership of Wiktor Romanowski ("Mister") and his substitute, Anatol Kurochkin ("Wiąz"), which served mainly as a liaison with the District Headquarters. Their duties involved operations that would nowadays be referred to as "logistics". They formed and dispatched groups of volunteers, organised the transport of medical supplies, Molotov cocktails [...]. The agency, as it was sometimes called, looked for beds for the wounded in hospitals or in conspiratorial apartments, cooperated with the patrols delegated to the city to perform certain tasks [...]. This improvised, and ultimately successful activity was supervised by "Mister", head of the group consisting of: Anatol Kurochkin ("Wiąz"), Władysław Baniuk ("Turmont"), Zdzisław Christa ("Mamut") and Ryszard Poszytek ("Bałtyk"). ${ }^{110}$

Another Polish citizen of Russian origin (and Orthodox confession) was Włodzimierz Jurasow ("Wiarus"), a native of the Wilno Land. He was born on 26 August 1923 in Wilno, as the son of Yuri and Mariya, a Russian Orthodox couple. Włodzimierz completed the King Sigismund Augustus Gimnasium and Liceum in Wilno/Vilno. Many of Jurasow's friends whom he knew back from school days would soon become legends of the resistance. Włodzimierz's first and foremost extracurricular activity was sailing since he had been admitted to the Romuald Traugutt $1^{\text {st }}$ Wilno Scouts Team (Błękitna Jedynka Żeglarska - Azure First Sailing).

After the outbreak of World War II, although rather not before June 1941, and "most likely in late 1942", he began to operate within the ZWZ Independent Area Wilno. The wharf of the Scouts' sailing club at the confluence of the Wilia (Lithuanian: Neris) and Wilejka [Vilnia] rivers served as a meeting place of the Wilno Home Army. After one year and a half, on 22 October 1943, ten conspirators under the command of Marian Korejwo ("Milimetr") have been smuggled out of the city on a lorry. The Vilnian volunteers ended up in the unit of Lt. Gracjan Fróg ("Góral", and "Szczerbiec" since November 1943). Józef Bandzo ("Jastrząb"), who had joined the unit two weeks prior to Jurasow, remembered it as follows: "There were twenty-four of us, and then thirty-four since they [Korejwo's subordinates] joined us. I met Jurasow in October 1943. My colleagues had told me that Jurasow was Russian, although no one ever asked such questions. It was just something someone said, but otherwise we went by our nicknames. I later befriended Jurasow, but already behind the Curzon Line". This is how the core of the Home Army $3^{\text {rd }}$ Wilno Brigade was formed. ${ }^{111}$

The commander assigned Jurasow, whom he nicknamed "Wiarus", to Korejwo's section of Władysław Markowski’s ("Dżumba") squad. The Russian took an oath on 11 November 1943, thus beginning the life of a Home Army partisan, even though he had no military skills. In an atmosphere of harsh discipline, "Wiarus" underwent intensive training under supervision of Romuald Rajs, achieving high combat efficiency. Marian Korejwo remembered well who was in charge of the training:

\footnotetext{
110 Korejwo, Moje ścieżki partyzanckie, pp. 64-65.

111 Testimony of Józef Bandzo, June 2015, Author's archive.
} 
Kapral (LCpl.) "Bury" (training), who had been promoted in the brigade up to the rank of $2^{\text {nd }}$ lieutenant. Before the war, he served in the $85^{\text {th }}$ infantry regiment $\left[85^{\text {th }}\right.$ Vilno Rifle Regiment - 85. pułk strzelców wileńskich] at Nowa Wilejka. He was an excellent instructor, merciless in achieving his primary goals. He made us sweat blood. [...] Instead of resting, we studied weapons, topography, cleaning weapons, etc. We got to know the weapons we were using, accurately and in-depth. ${ }^{112}$

Włodzimierz showed great physical prowess, which he demonstrated at the beginning of November 1943, when he helped his 38-strong unit considerably as they were crossing a river: "Then two of our boys - "Wiarus" being an excellent swimmer - swam across the relatively wide river [Wilia] in spite of its icy waters of early November, and dragged the boat to our side". ${ }^{113}$

One of Jurasow's first experiences in combat was the successful attack on a post, manned by platoon of the Litauische Polizei Bataillon F/256 in the village of Worniany. By breaking the prison gate down with blacksmith hammers, the partisan unit freed 70 people (including a group of Jews) from the local detention facility. Later, in the autumn of 1943 (after the burning homes and murdering Polish inhabitants at Naliboki), the relations with the Soviet partisans operating in the Eastern Borderlands (West Belarus and Białystok) have become openly hostile. The Soviet units fighting against the Home Army's "White Poles" (counter-revolutionary Poles) were subordinated to the Belarusian Staff of the Partisan Movement (Belorusski shtab partizantskogo dvizheniya). This led to incidents such as: "[In] mid-November 1943, near Mikuliszki, a Soviet group was strafed by 'Wiarus', who was standing guard". ${ }^{114}$

One month later, Jurasow joined the $3^{\text {rd }}$ Brigade AK. Olgierd Christa recalled his first "partisan" encounter with his "colleague of Russian descent from both school and the $3^{\text {rd }}$ Brigade" as follows: "In the group, I have met two of my friends from school days, Włodzimierz Jurasow ("Wiarus") and Henryk Siemaszko ("Dłuższy"). They impressed us with their equipment, their binoculars, the leather belts on their chests [Sam Browne belts known as koalicyjki]. It was early winter season, and by lack of military coats they wore overcoats that proved comfortable during the march. Włodzimierz took part in subsequent skirmishes of the unit". ${ }^{115}$

The year began with an attack launched by several platoons of Lithuanian auxiliary police and German gendarmerie under the command of Leutnant Schnabel; the Home Army partisans, however, managed to fend it off. On 8 January 1944, The Poles were quartered in Mikuliszki. "Wiarus", who was well trained in the use

112 Korejwo, Moje ścieżki partyzanckie, p. 45

113 Ibid., p. 44.

114 Christa, U "Szczerbca" i "Eupaszki”, p. 72; Korejwo, Moje ścieżki partyzanckie, pp. 36 and 39-41; J. Bohdanowicz, 3. Brygada Szczerbca Armia Krajowa Okręg Wileński, Warszawa, 2008, p. 4, http://www.muzeum-ak.pl/slownik/UserFiles/File/wilno-brygada-szczerbca.pdf (access: 7 May 2017).

115 Christa, U "Szczerbca" i "Łupaszki”, pp. 36-37. 
of his $7.62 \mathrm{~mm}$ light machine gun Degtyaryov M1927 (DP-27) "would demonstrate the method of disassembling and reassembling the weapon. He was section leader and gunner at the same time. [...] Along came "Wiarus" with his ammunition man "Szwagier". Wiarus deployed his diegtar [DP-27 machine gun] between the house and a tree nearby and began spraying the enemy's formation with bullets. The formation was broken instantly, and the survivors ran away to hide behind bushes in the swamps", recalled Korejwo. ${ }^{116}$

The Polish fighters received support from a mounted reconnaissance unit. The cavalrymen attacked the flank of the assault line, forcing the Lithuanians to retreat, as they had lost up six Gendarmerie functionaries (Ltn. der Gend. Schaabel, Hauptw. Michalowski, Obw. Hebel, Hauptw. der Gend. Lueker, Bez. Obw. der Gend. Kuklinski, Obw. Roesler) and 19 Lithuanian policeman of LVR (Polish sources mentioned higher losses even 32-40 men). Five AK partisans died in the operation, including Lt. Piotr Motylewicz ("Szczepcio"); all have been buried in Mikuliszki, where the local cemetery served as resting place for Fróg's fallen soldiers. It was at that time that the Lithuanian policemen taken prisoners who had been accused of allegedly committed war crimes were shot. From late December 1943 to end-February 1944, the $3^{\text {rd }}$ Brigade cooperated with $6^{\text {th }}$ Brigade commanded by Lt. Adam Boryczka ("Tońko"), soldier of the "Silent Unseen" (Cichociemni, CC). ${ }^{117}$

The next Polish-Lithuanian struggle took place on 4 May 1944 at Pawłów. It was the place of rest of the $1^{\text {st }}$ Company of $310^{\text {th }}$ Battalion LVR, marching from Jaszyny to Turgiel. And at that place the Lithuanians murdered two civilians and two other they seriously wounded. The civilian population of the town was supported by the $3^{\text {rd }}$ Brigade AK, who crashed the unit of Lithuanian policemen. Four Lithuanians were killed in the fight, and eight were taken prisoners. The commander of the Lithuanian $1^{\text {st }}$ Company, Capt. Vytautas Narkevicius, and two of his non-commissioned officers were shot under the order of Capt. "Szczerbiec" for crimes against civilians. The Poles set free the fourth POW, with a letter addressed to the commander of the $310^{\text {th }}$ Battalion. ${ }^{118}$

116 Korejwo, Moje ścieżki partyzanckie, pp. 80 and 83

117 AAN, T - 454, roll 19, frame 91 (Abschrift, 2 V - Pr./C, [An Herrn Generalkommissar In Kauen - gez. Prollius] H. A. 2 V., Betr.: Sofortmeldungen; 10.01.1944) [I would like to thank Mr Jan Bańbor for turning my attention to this document]; E. Banasikowski, Na zew Ziemi Wileńskiej, Warszawa-Paryż, 1990, pp. 115-118; Christa, U “Szczerbca" i "Eupaszki”, pp. 41, 44-48; Korejwo, Moje ścieżki partyzanckie, pp. 65, 67-68; Bohdanowicz, 3. Brygada Szczerbca, p. 4; and Piotr Niwinski, "Die nationale Frage im Wilnagebiet", in: Die polnische Heimatarmee. Geschichte und Mythos der Armia Krajowa seit dem Zweiten Weltkrieg, ed. B. Chiari Berlin, 2003 (Series: Beiträge zur Militärgeschichte 57), p. 630.

118 R. Korab-Żebryk, Biała Księga. W obronie Armii Krajowej na Wileńszczyźnie, Lublin, 1991, p. 105, L. Tomaszewski, Wileńszczyzna lat wojny i okupacji 1939-1945, Warszawa, 1999, p. 437; and J. Wołkonowski, "Starcie polsko-litewskie", Karta, 32 (2001), p. 77; Krajewski, Na straconych posterunkach, p. 394. 
Later, Fróg's brigade, supported by the $8^{\text {th }}$ Brigade AK of Lt. Witold Turonek ("Tur"), $9^{\text {th }}$ Brigade AK of MSgt. Jan Kolenda ("Mały"), $12^{\text {th }}$ Brigade AK of Lt./ Capt. Hieronim Romanowski ("Cerber"), and $13^{\text {th }}$ Brigade AK of Lt. Adam Walczak ("Nietoperz") seized the town of Murowana Oszmianka on the night of 13/14 May 1944. They defeated the $1^{\text {st }}$ Company of the $310^{\text {th }}$ Battalion of Lithuanian Territorial Defence Force / Lithuanian Special Task Force (Lietuvos Vientiné Rinktine, LVR / Litauische Sonderverbände), commanded by Lt. Povilas Grigaliunas. In the battle of Murowana Oszmianka, the $8^{\text {th }}$ platoon ( $2^{\text {nd }}$ squad, $1^{\text {st }}$ assault platoon) of the $3^{\text {rd }}$ Brigade was commanded by Jurasow. The $2^{\text {nd }}$ company, $310^{\text {th }}$ Battalion of the LVR, commanded by Eduardas Počebutas, has also been defeated in Tołminowo. The Lithuanians lost 60 KIA policemen, and 200 policemen became short-time Polish POWs, to be then released - wearing nothing but underwear (undershirts, drawers and underpants) - in direction of Wilno/Vilno, Jaszuny [Lithuanian: Jašiūnai] and Oszmiana. During fighting 10-11 AK partisans were killed, and 20-25 more wounded. "Wiarus" was then promoted to the wartime rank of Second Lieutenant. Among other exploits of the $3^{\text {rd }}$ Brigade were skirmishes and the disorganisation of the German administration in Biała Waka, Czarny Bór, Kienia, Mickuny, Rudomin Szumsk and Wojdaty. Next, Lithuanian Police prepared pacification in Adamowszczyna (five murdered and burning village), Korabów (burning seventeen settlers), Powiszyn (beaten seven Poles) and Sieńkowszczyźna (four killed and three houses burning). A major clash was fought on 6 May, and is known as the Battle of Graużyszki. Thirty seven Lithuanian policemen were killed, and sixty wounded; thirty Lithuanians were taken POWs. Two days later there was another military scuffle, near the Lithuanian village of Koniawa, but the fight was unresolved. The company of Lt. Piotr Słonina "Piotr" of the $6^{\text {th }}$ Brigade AK lost twelve partisans. In July 1944, Jurasow fought for Wilno/ Vilno as commander of the $1^{\text {st }}$ Platoon, $4^{\text {th }}$ Company of the Home Army $3^{\text {rd }}$ Wilno Brigade, under Capt. Fróg. Jurasow later shared the tragic fate of the Wilno AK (Home Army) Brigades, whose commanders have been arrested, and the majority of soldiers have been sent to the camp in Miedniki Królewskie. ${ }^{119}$

After the arrest of "Szczerbiec", the commander in charge of the $3^{\text {rd }}$ Wilno Brigade, 2nd-Lt. Rajs managed to demobilise most of his subordinates and conceal

119 AAN, T-311, roll 213, frames 000905-906, Bericht über Einsatz d. Litauische Polizei-Bataillonen in Raum Wehrmacht Befehlshaber Weissruthenien vom 19 Mai 1944; Banasikowski, Na zew Ziemi, pp. 128-135; Christa, U “Szczerbca" i "Eupaszki”, pp. 81-82; Z. Kłosiński, 3 Wileńska (Białystok: Redakcja Gońca Kresowego - Białostocki Oddział Towarzystwa Przyjaciół Grodna i Wilna, 1995), p. 129; Korab-Żebryk, Biała Księga, p. 109; Korejwo, Moje ścieżki partyzanckie, pp. 77-79, 121-133, 142-143; N. Thomas, C. Caballero, Germany's Eastern Front Allies (2): Baltic Forces, Oxford, 2012, pp. 37-38; H. Piskunowicz, "Działalność zbrojna Armii Krajowej na Wileńszczyźnie 1941-1945”, in: Z dziejów Armii Krajowej na Nowogródczyźnie i Wileńszczyźnie (1941-1945). Studia, ed. Z. Boradyn, A. Chmielarz, H. Piskunowicz, Warszawa, 1997, p. 40; L. Tomaszewski, Wileńszczyzna lat wojny i okupacji 1939-1945, Warszawa, 1999, p. 437; and Wołkonowski, Starcie polsko-litewskie, p. 79. 
their weapons. However, a 120-strong group of partisans (including "Wiarus"), still armed with old Belgian rifles, decided to head to Wilno/Vilno, hoping for official disarmament, which was carried out by units of the Internal Troops of the NKVD. This decision resulted in the deportation of 2nd-Lt. Jurasow and several dozen other soldiers of the Home Army $3^{\text {rd }}$ Wilno [AK] Brigade; in August 1944, he was sent to a filtration camp established in the former stables of the Miedniki Królewski Stud, where "even 7-8 thousand detainees had been crammed". "Wiarus" managed to flee with three colleagues; "Milimetr" recalls this event as follows:

I met with "Wiarus", who had served as platoon commander ( $4^{\text {th }}$ Company, $3^{\text {rd }}$ Brigade), and with two colleagues from the $6^{\text {th }}$ Brigade (commanded by "Konar"). We decided to flee $[\ldots .$. . Showing no signs of hurry, we walked past one camp guard, and then another. Halfway between the second and third guard, at a given signal, we rushed to the bushes on our left. We started to sprint, as if it were a hundred-metre dash. [...] After running about $100 \mathrm{~m}$, we headed north-east towards an estate [near Miedniki], where we were supposed to find clothes and possibly some documents.

They were also given moonshine (samogon), which allowed them to pay a Soviet truck driver "with liquid currency" so he would take them to the village of Góry. From there, they proceeded on foot via Górna Kolonia Wileńska [Lithuanian: Aukštasis Pavilnys], successfully avoiding the NKVD patrols and eventually reaching their hometown. ${ }^{120}$

Little is known with certainty about Jurasow's stay in Wilno/Vilno after his escape from the camp; like most of the former conspirators, he probably tried to make ends meet while reviving former contacts. Later, like many of his colleagues, he was repatriated to the Polish territory behind the Curzon Line. Shortly after the end of hostilities in May 1945, Jurasow met in Kraków with a former colleague from the AK $3^{\text {rd }}$ Wilno Brigade, Henryk Siemaszko ("Dłuższy"). "Wiarus" declared that he was departing to Podlasie to fight for free elections by joining the $5^{\text {th }}$ Brigade of Major Zygmunt Szendzielarz ("Eupaszka"). ${ }^{121}$

The brigade was joined by 2nd-Lt. Romuald Rajs ("Bury"), who assumed command of its $2^{\text {nd }}$ Squadron; among other soldiers were Sgt. Kazimierz Chmielowski (“Rekin”), Sgt./2nd-Lt. Mikołaj Kurochkin ("Leśny”), Cpl. Józef Bandzo (“Jastrząb”), LCpl. Tadeusz Urbanowicz ("Moskito"), and from July to September 1945, "Wiarus". The demobilisation of the AK $5^{\text {th }}$ Brigade did not mean the end of Jurasow's military engagement, who then reported for duty to the command of the NZW Białystok District with his superior and a portion of the $2^{\text {nd }}$ Squadron. The transition to the NZW as $3^{\text {rd }}$ Wilno Brigade proved to be a rocky one, due to war exhaustion and decreasing morale among the soldiers who felt threatened and hounded by the "stabilisers of the regime". During the partial demobilisation

120 Korejwo, Moje ścieżki partyzanckie, pp. 176-177.

121 Banasikowski, Na zew Ziemi, pp. 348-349; and Korejwo, Moje ścieżki partyzanckie, pp. 250, 262. 
of the $2^{\text {nd }}$ Squadron, a conflict regarding the allegedly insufficient protection of demobilised soldiers emerged between "Jastrząb" and "Bury". "Rekin" made an attempt to shoot himself as he heard the argument and the threats being made to "Jastrząb". "Wiarus" managed to prevent the suicide only in the last moment by slapping Chmielowski's hand. Shortly after the next briefing, "Wiarus", "Rekin" and "Jastrząb" left for vacations. Jurasow thus spent some at his friend's, O. Christa, who served in the Polish-communist" $62^{\text {nd }}$ Infantry Regiment at Ełk. ${ }^{122}$

Upon return from vacation, the experienced Vilnian partisans quickly turned the NZW $3^{\text {rd }}$ Brigade into a disciplined unit. "Wiarus" was promoted to the rank of second lieutenant and assumed command of the $1^{\text {st }}$ Platoon (when the "brigade" numbered about 90 soldiers). The first operation following the reorganisation of the NZW $3^{\text {rd }}$ Brigade was the disarmament of the communist contingent group and MO post crew at Sokoły. On the penultimate day of 1945, the unit attacked the outpost in Sokoły, which ultimately agreed to surrender to "Wiarus" and "Rekin". In mid-January, when "Bury" returned, the brigade was pursued by an UB/MO operational group. Owing to his forest experience, Capt. "Bury" managed to lose the pursuit, which withdrew to Białystok. Meanwhile, the NZW $3^{\text {rd }}$ Brigade launched an attack on Hajnówka on 28 January 1946. Jurasow's platoon entered the city as vanguard, protecting the road between Bielsk and Hajnówka. "Wiarus" as commander kept a cool head when his troops encountered a Soviet transport column; the "Cursed Soldiers" would pretend to be conducting a military training, making the Soviets believe they were from the People's Army. Jurasow then seized the local MO post and disarmed the officers, beginning his "tenure" with the arrest of several Soviets. Increasingly intense fire from the railway line forced the platoon, as well as other sub-units of the NZW $3^{\text {rd }}$ Brigade, to retreat. The night-time operation in Hajnówka was followed by several controversial incidents at the behest of "Bury". During the retreat through the terroritory of the Bielsk Podlaski county, five villages inhabited mainly by Belarusians (Zaleszany, Wólka Wyganowska, Zanie, Szpaki and Końcowizna) have been burnt down by soldiers of NZW $3^{\text {rd }}$ Brigade. On February $2^{\text {nd }}$, the platoon commanded by a certain "Leszek" (real name unknown), presumably supported by Jurasow's men, engaged in combat with a pro-communist self-defence militia guarding the village of Szpaki, composed of former Soviet partisans. 22 buildings were burnt down by Poles, six men were killed, and one person died as a result of burns. The platoon headed by "Bitny" too fought with local pro-communist self-defence militia at Zanie, which led to the burning of 14 of the 22 houses there. The attack swept 24 to 30 casualties (including women and children). Jurasow's unit, on the other

${ }^{122}$ Kułak, Rozstrzelany oddział, pp. 125-129; id., “Organizacja i walki III Wileńskiej Brygady NZW (Narodowego Zjednoczenia Wojskowego) kpt. Romualda Rajsa 'Burego’ (1945-październik 1946 r.)”, in: Dzieje polskiego podziemia na Białostocczyźnie w latach 1939-1956. Materiały z sesji naukowej, 24 kwietnia 1992 r. w Instytucie Studiów Politycznych PAN, ed. M. Giżejewska, Toruń, 1992, pp. 80-81. 
hand, burnt three houses in Końcowizna, but without any victims. In total, the PAS units of the NZW District under Rajs's command killed nearly 75 people of Belarusian nationality between January $29^{\text {th }}$ and February $2^{\text {nd }}$. The pacification of five villages, the incident in Hajnówka, and the execution of 30 coachmen in the woods near the village of Puchały Stare led to the dispatching of a joint SovietPolish operational group against NZW $3^{\text {rd }}$ Brigade. ${ }^{123}$

The command of the district decided to transfer Rajs's unit to the southern part of East Prussia, which had been incorporated into Poland. Initially, no one would expect a tragic outcome. Untroubled by the communists, the $3^{\text {rd }}$ Brigade first reached the village of Gajrowskie, where it was discovered by an operational group of the $2^{\text {nd }}$ Mot. Rifle Rgt. of Vnutrenniye Voyska NKVD (Internal Troops NKVD) under the command of Major Serukhin, supported by armoured vehicles BA-64. Having been ambushed, the "Unbroken Soldiers" took up, on 16 February 1946, an uneven fight. The partisans managed to damage one of the Soviet armoured vehicles. The next day, the unit was surprised during a rest stop by the NKVD pursuit group supported by WP [Polish Army] and UB sub-units. A chaotic clash occurred in the area of Gajrowskie (Wydminy commune, Giżycko county). Rajs's subordinates suffered serious casualties ranging from 14 to 19 killed, including 2nd-Lt. Jan Boguszewski ("Bitny") and Lt. Włodzimierz Jurasow ("Wiarus"). In addition, the Soviets captured three Polish partisans at a price of 2 killed and 6 wounded. ${ }^{124}$

123 The actions of the NZW had a political background, as they were perceived as an act of retaliation for the support shown to the Soviet and Polish communists by the local population. Such was the main cause of the pacification, rather than a presumed religious/ethnic conflict between Poles and Belarusians or between the Catholics and the Orthodox. The actions of Rajs's subordinates do not constitute a genocide of Orthodox Belarusians; several dozen or hundred victims cannot be considered genocide in terms of either form, scale, course or consequences. Also, few people seem to notice that there also were some Orthodox Christians among the soldiers and officers of the NZW $3^{\text {rd }}$ Brigade (such as Kurochkin and Jurasow), and they have never been discriminated against because of their religion or origin. It should be emphasised that the decision of the Military Regional Court in Warsaw of 15 September 1995, which declared the communist verdicts of the Military District Court in Białystok of 1 October 1949 and 3 March 1950 invalid, is more important from a legal standpoint than the later final report from the investigation by the prosecutor office in 2005, which does not have legal force; see: Bechta, Muszyński, Przeciwko Pax Sovietica, pp. 265-267; S. Iwaniuk, "Represje polskiego podziemia wobec ludności białoruskiej na Białostocczyźnie po lipcu 1944 roku”, in: Stosunki polsko-białoruskie $w$ województwie białostockim w latach 1939-1956, eds. J.J. Milewski, A. Pyżewska, Warszawa, 2005, p. 101. The author mentions as many as 422 Belarusians (including 296 civilians, $66 \mathrm{UB} / \mathrm{MO} / \mathrm{ORMO}$ officers and $60 \mathrm{PPR}$ members, of which at least 284 were victims of the Polish underground independence); and Kułak, Rozstrzelany oddział, pp. 231-248.

124 Bechta, Muszyński, Przeciwko Pax Sovietica, pp. 268-269; K. Krajewski, T. Łabuszewski, "Łupaszka", "Młot", "Huzar". Działalność 5 i 6 Brygady Wileńskiej AK 1944-1952, Warszawa, 2002, pp. 265-266; Kułak, Rozstrzelany oddział, pp. 276-310; and G. Motyka, Na białych Polaków obława. Wojska NKWD w walce z polskim podziemiem 1944-1953, Kraków, 2014, pp. 285-286 (the Soviet unit was under command of Capt. Makarenko). 
The aforementioned Major Szendzielarz was in a relationship with another Polish partisan of Russian descent, Lidiya Lvova [Lidia Lwow]. She was born on 14 November 1920 in Plyos into the family of an agricultural engineer. From her mother's side (Barbara, née Tyukhanov), she belonged to a Russian noble family, although not a ducal one. ${ }^{125}$

My parents were Russians, and I am Russian. My father was born in an estate near Bobruisk. Dad graduated from agricultural studies in Moscow; back then he was fascinated by socialism; and mum - by botany. My parents left everything behind in Russia during World War I. My grandmother wanted my father to move to Poland. In Russia, Bolshevism was raging and terrible things were happening.

Polish blood is also flowing in our veins from my father's side. My parents met on the war front, where my father was serving, even though he was not a military man. As the only son in his family, he had not been conscripted. He was a supplier. He proposed to my mother fairly quickly, and they relocated to the Celewicze estate, where his family lived", recalls Lidiya Lvova. "As for grandma, she completed the Wilno/Vilno Institute for Noble Maidens at the age of eighteen, where she happened to meet my grandfather, Ivan Lvov, a young officer, three years her senior.

They soon married and settled in St. Petersburg. My grandfather was a gambler. I do not remember how many children they had, but two survived: daddy as the younger one, and one aunt who was three years older. My great-grandfather was very concerned about my grandmother, his only daughter, as his wife and second daughter had died; he convinced her to file for divorce. Dad was ten when my grandmother divorced her husband. My great-grandfather immediately took her to Italy to make her forget about that man. Then my grandmother met a "second uncle", who was slightly younger than her. They lived a long and happy life, and she was surrounded by care and abundance. They raised my father together. ${ }^{126}$

When the Lvov family settled in Poland in 1921, Lidia's father became a teacher at a Russian gymnasium in Nowogródek, and then a lecturer at an agricultural school in the suburbs of this provincial town. Eventually, owing to his qualifications, he was appointed county agronomist. Lidia attended the private course run by Sisters of the Holy Family of Nazareth at Nowogródek, preparing to school. Next she educated in Adam Mickiewicz State Gimnasium Nr 919 in Nowogródek and Józef Piłsudski's State Gimnasium at Święciany; she passed her matriculation in 1938. She would spend her holidays around Wilno, at the banks of Narocz, the largest Polish lake at that time. ${ }^{127}$

She was then admitted to the Faculty of Law at the Stefan Batory University in Wilno:

125 Русская княжна - партизанка Армии Краёвой, http://www.istpravda.ru/bel/digest/1231/ (access: 17 January 2017).

126 Testimony of Lidia Lwow-Eberle, March 2015, Author's archive.

127 AIPN BU, 0 259/436, vol. 10, Stenogram z 4, 5, 6 dnia rozprawy p-ko Olechowiczowi Antoniemu i innym, rok 1950 [Shorthand report of day 4, 5 \& 6 of trial against Olechnowicz Antoni et al.], fol. 46. 
We went to study together with a Jewish friend of mine. Hence probably the nickname I received: “judejka/żydówka?" [Jewess] At the university, I witnessed the horrible treatment of Jews; they were not allowed to sit on the benches, having to stand during the lectures instead. But at the university, just like at school, I used to spend time and talk with my Jewish colleagues; as a result, I was once informed by a boy from my group: "If you continue to talk to the Jews, eventually we will have to treat as one of them". But as a Russian, I did not encounter any harassment. ${ }^{128}$

She had just completed her first year of law studies when the war broke out. After the Soviet invasion of Poland in 1939, Lidia ended up in Kobylnik, the town where her father worked (he was deported to the Ural Mountains to work in forests and the local kolkhoz, and survived) and her mother and younger brother Boris lived (he was later conscripted into the Polish-communist Second Army). ${ }^{129}$ Lidia worked as a teacher at a rural school in the village of Pletyasha:

My parents no longer lived in the same house, where there was no room for them anymore. They began working in the forest. The forester, a Pole, would give jobs to all the young people around. This way they have not been taken away for forced labour after Germany invaded the country. My brother kept working in forestry, becoming a stoker, and my mother and I also joined in. Mum became manager of a small dairy in Kobylnik. At least we had milk, cream... instead of money. Then I worked as a teacher, this time in Kupa, a small village near the lake Narocz. ${ }^{130}$

In an interesting turn of events, she was admitted to the Home Army unit "Burza"; as she recalls:

It was in the summer of 1943. Since early spring, the first partisan unit of the Home Army Wilno District operated in the region of Postawszczyzna [?] under the command of "Kmicic" [Lt. Antoni Burzyński]. He knew me personally, and one day he told me that I could prove myself useful in his unit. I agreed to join the Home Army. One summer day, people wearing uniforms of the Belarusian police [Schutzmannschaft auxiliary police] drove to my house on a cart and took me with them. I did not realise what had happened. But as soon as we drove away, they immediately switched from Belarusian to Polish. They told me they have come to pick me up, so I could join the unit. ${ }^{131}$

In the summer of 1943, Lidiya Lvova joined the ranks of the Home Army partisan unit operating in the Vileyka County and commanded by 2nd-Lt. Burzyński. Lvova used the conspiratorial noms de guerre "Ewa" and "Lala"; she worked as

128 Testimony of Lidia Lwow-Eberle, March 2015, Author's archive.

129 AIPN BU, 0 259/436/17, vol. 2, Akta śledztwa w sprawie o przynależność do AK prowadzonemu przeciwko Antoni Olechnowicz, imię ojca: Ferdynand, ur. 13-06-1905 r. Doniesienie agenta "Gumka"; 25.10.1950 [Case file regarding suspected activity of Antoni Olechnowicz in the AK], fol. 189.

130 Testimony of Lidia Lwow-Eberle, March 2015, Author's archive.

131 Ibid. and Русская княжна. 
a cook. According to her assessment, the unit was initially in good terms with the Soviet partisans, but the Soviet policies ultimately led to a bloody armed confrontation. ${ }^{132}$ Burzyński's unit was crushed on 26 August 1943 by the Soviet "Voroshilov" Partisan Brigade commanded by "Col". Fyodor Markov. ${ }^{133}$

After the war, Lvova testified before the communist court as follows:

Two weeks later, the unit has been disarmed by Soviet partisans; they took the commander away, and with him about 60 other men, of whom only some later returned to the unit. We were placed under the authority of the Soviet partisan forces and given a new commander, "Zapora" ["Captain"/Corporal Wincenty Mroczkowski]. [...] One month later, the unit [i.e. the "Bartosz Głowacki" Partisan Unit] under the command of "Zapora", numbering around 60, marched out of hiding in order to establish contact with other troops in the area. Once they were in touch, the Poles fled to "Eupaszka". After some negotiations I joined his unit. It was in late September 1943. From that moment I had assumed the duties of medical orderly, and I remained in this unit until April 1947. ${ }^{134}$

\section{More fierce fighting flared up}

[...] around Sięcinięta [Belarusian: Syentsyanyaty] near Swir in October 1943, where the concentration of troops of Szendzielarz's $5^{\text {th }}$ Brigade and Olechnowicz's platoon V $\left(5^{\text {th }}\right)$ Partisan Unit commanded by 2nd-Lt. Roman Olechnowicz, nom de guerre "Mars" (core of the future AK $12^{\text {th }}$ Oszmiany Brigade)?] was being conducted. A skirmish with a 9-strong group of Soviet partisans took place, three of whom were killed, while the rest have run off, only to encounter a Lithuanian unit which wiped them out. In mid-October 1943, in the village of Bibki near Świr, Szendzielarz's troops defeated the food supply platoon of the Soviet partisans, seizing all their stock. On the next day, between the villages of Bibki and

132 AIPN BU, 0 259/436, vol. 1, Wyciąg z raportu Wydz. II. Dep. Śledczego z dn. 15.11.48; Warszawa, 18.11.1948 [Excerpt of report of Sect. II of Inv. Dept.], fol. 216; A. Tarnawska, "Zamiast broni miałyśmy lekarstwa", Nowy Dziennik. Polish Daily News, Garfield, New Jersey, http://www. dziennik.com/wiadomosci/artykul/zamiast-broni-mialysmy-lekarstwa (access: 17 January 2017). Commander of Polish AK partisan 2nd-Lt. "Kmicic" has been subjected to torture, then murdered by Soviet partisan. The next day, each of the Polish partisans was summoned for interrogation at the office of the commander of the Brigade's special unit (specyalnyj otriad). The interrogation would result either in further incarceration, or an authorisation to move freely around the camp. Those who were guarded by partisans (around 80 people) have eventually been taken out of the camp and executed in the forest. Only three partisans ("Długi", "Szpagat" and "Ursus") managed to flee. Meanwhile, a prison informant reported on the fate of "Ewa" in the following words: "Markov incorporated the Polish partisans into his otryads [units], including Lvova, whom Markov knew personally as a [pre-war Polish citizen and] resident of Święciany; it was even suspected that Lvova was a former flame of his"; see: AIPN BU, 0 259/436/17, vol. 2, Akta śledztwa w sprawie o przynależność do AK prowadzonemu przeciwko Antoni Olechnowicz, imię ojca: Ferdynand, ur. 13-06-1905 r., Doniesienie agenta "Gumka", 25 X 1950 [Case file regarding suspected activity of Antoni Olechnowicz in the AK], fol. 189; and Motyka, Na białych Polaków obława, pp. 70-71.

134 AIPN BU, 0 259/436, vol. 10, Stenogram z 4, 5, 6 dnia rozprawy p-ko Olechowiczowi Antoniemu i innym, rok 1950, fol. 27. 
Pracuły [Belarusian: Pratsuty], Szendzielarz's men ambushed the food supply group of the Soviet partisans, seizing all their stock again. On the same day, and in the same village, they ambushed a diversionary unit of the Soviet partisans. One Soviet partisan was killed in the event, and one woman from the same group committed suicide having no possibility to withdraw. ${ }^{135}$

In November, Polish-Soviet talks took place in Syrowatki [Belarusian: Syravatki], but to no solution. In the meantime, fierce fighting with the occupying forces broke out; in total, several dozen skirmishes with Lithuanian and German troops, successful offensives against about fifty police posts and railway stützpunkten, and this in spite of the negotiations of the Home Army with the Germans (Abwehr, later Sipo/SD). ${ }^{136}$

The fighting stopped for wintertime; the troops would take advantage of this time to improve their tactics and practise with weapons. Clashes with the Soviet partisans began anew near the end of winter: "On February $2^{\text {nd }}$ [1944], after a heavy fight with the Germans, we withdrew back to the Sieradziszcze area where we were stationing, as we had six seriously wounded. On the next day, we were attacked by Soviet partisans, who outnumbered us by far. There were casualties on our side" ${ }^{137}$ In mid-February, a skirmish took place around Jasin [Belarusian: Yasyen'] near Michaliszki; Lvova recalled the outcome of this battle as follows: "What happened is that were quartered with the whole brigade in the village of Jasin. A Soviet patrol entered the village in the middle of the night. Fighting began and lasted until 10 a.m., but we had to withdraw due to lack of ammunition. [...] I was with the unit as their orderly all the time. It was the same fight that started in Jasin, and ended near Zukojny". ${ }^{138}$

The clashes intensified shortly before Operation "Bagration", as mentioned in one dialogue in post-war communist court: "Then, in May 1944, an offensive against the staff of the Soviet counter-intelligence was initiated in that same village [Sięcinięty]. What does the defendant remember? I only remember that one incident in May 1944". ${ }^{139}$

135 AIPN BU, 0 259/436, vol. 4, Postanowienie o pociągnięciu do odpowiedzialności karnej Lidii Lwow, Warszawa 18.01.1950 [Court order on liability for prosecution against Lidiya Lvova], fols. 68-69.

136 AIPN BU, 0 259/436, vol. 1, Wyciąg z raportu Wydz. II. Dep. Śledczego z dn. 15.11.48, Warszawa, 18.11.1948, fol. 216; J. Wołkonowski, Okręg Wileński Związku Walki Zbrojnej Armii Krajowej w latach 1939-1945, Warszawa, 1996, pp. 171-184.

137 AIPN BU, 0 259/436, vol. 10, Stenogram z 4, 5, 6 dnia rozprawy p-ko Olechowiczowi Antoniemu i innym, rok 1950, fol. 27.

138 AIPN BU, 0 259/436, vol. 10, Stenogram z 4, 5, 6 dnia rozprawy p-ko Olechowiczowi Antoniemu i innym, rok 1950, fol. 30.

139 The counter-intelligence service supposedly operated beside the partisan brigade of Colonel Monakhin [?]; see: AIPN BU, 0 259/436, vol.10, Stenogram z 4, 5, 6 dnia rozprawy p-ko Olechowiczowi Antoniemu i innym, rok 1950, fol. 35; and AIPN BU, 0 259/436/17, vol. 3, Postanowienie o pociągnięciu do odpowiedzialności karnej Lidii Lwow, 18.01.1950, fol. 102. 
Most Polish-Lithuanian fights would end with no casualties, but not that of the $5^{\text {th }}$ Brigade AK under Glinciszki (Lithuanian: Glitiškes; Belarusian: Hlintsishki), where four Lithuanian policemen have perished on June $19^{\text {th }} / 20^{\text {th }}$. This provoked a reprisal by police officers of the $3^{\text {rd }}$ Company of the 258-asis lietuviu policijos batalionas (German: Litauische Polizei-Ers. Bataillon Nr. 258) commanded by Lt. Polekauskas. The Lithuanians massacred 39 Polish residents of the village, including four children. The Polish retaliation was even more horrifying, as the AK $5^{\text {th }}$ Brigade went on a raid deep into the Lithuanian territories around Kaunas. The Poles murdered up to one hundred Lithuanian nationals; mostly police officers, but the casualties also include 20-27 residents of Dubinki [Lithuanian: Dubingiu] and the neighbouring villages of Janiszki [Joniškis], Inturkie [Inturkè], Bijuciszki [Bijutiškis] and Giedrojcie [Giedraičiai], all killed on June $23^{\text {th }}$. Later, 550 soldiers of Szendzielarz's $5^{\text {th }}$ Brigade were assigned to Group I to prepare for Operation "Ostra Brama", the objective of which was to seize Wilno/Vilno, as part of the wider objectives of Operation "Burza" ("Tempest"). ${ }^{140}$

Ultimately, rotmistrz Szendzielarz ordered withdrawal westwards before the attack (to which he had oral consent of the Home Army Independent Area Wilno Commander, although given in different circumstances): "We found ourselves in the Świsłocz Forest after leaving the Wilno/Vilno area. [...] I think it was July or September 1944". ${ }^{141}$ Lidiya Lvova had secretly crossed the Curzon Line with Zygmunt Szendzielarz. They spent the winter together at the Białowieża Forest. The Brigade was mobilised at the beginning of April 1945 in the Oleksin area; the unit of Maj. Szendzielarz engaged in fight with regular units of the Red Army and Internal Troops of the NKVD, the Polish Army, and the future Internal Security Corps (KBW), as well as groups of the UB and MO. The partisans paid particular attention to killing UB agents and PPR members, whom they considered traitors. The brigade raided $\mathrm{MO}$ posts and communal offices, setting up ambushes. Only in April 1945, Szendzielarz's brigade participated in several clashes; first, at the beginning of the month, they initiated an attack on an ambush prepared near the village of Kapitańszczyzna by the Polish-communist Army and the Red Army. Two weeks later, near Siemiatycze, they disarmed a Polish sub-unit guarding the bridge on the Bug River (although, during the war, the bridges in the vicinity of the Belarusian and Eastern Prussian war fronts were protected by the $14^{\text {th }}$ Rifle Division VV NKVD assigned to the protection of railway lines), and then, in

140 Korab-Żebryk, Biała Księga, pp. 130-139; id., Operacja Wileńska AK, Warszawa, 1988, p. 135; Krajewski, Na straconych posterunkach, p. 404; Motyka, Na białych Polaków obława, p. 79; P. Rokicki, Glinciszki i Dubinki. Zbrodnie wojenne na Wileńszczyźnie w połowie 1944 roku i ich konsekwencje we współczesnych relacjach polsko-litewskich, Warszawa, 2015; and Wołkonowski, Okręg Wileński, pp. 246-247.

141 AIPN BU, 0 259/436, vol. 10, Stenogram z 4, 5, 6 dnia rozprawy p-ko Olechowiczowi Antoniemu i innym, rok 1950, fol. 37; Krajewski, Na straconych posterunkach, p. 604; and Motyka, Na białych Polaków obława, p. 93. 
late April, they attacked the MO post at Narewka, where they executed three "collaborators of the UBP" and proceeded with the flogging, as Lvova testified:

of a young woman of an unknown name, who, according to Szendzielarz's knowledge, worked for the NKVD and was a resident of Narewka. "Eupaszka" decided to interrogate the woman for a few minutes, and then ordered that Jerzy Lejkowski ("Szpagat”) and "Florek" punish her by flogging. [Crossed-out text] The two men carried out said punishment, which consisted of beating the woman with a leather whip used for riding on horseback. After this, at the behest of "Lupaszka", the squadrons of "Zygmunt" and "Mścisław" [crossed-out text].

\section{Simultaneously,}

In late April 1945 "Lupaszka” departed to Hajnówka for a meeting with "Bury”, while I followed the squadrons of "Zygmunt" and "Mścisław" to the village of Łozy, in the Białowieża Forest. We marched out of this village the very next morning to meet with "Eupaszka" in the forest, near the narrow-gauge track. There, he instructed Lech Beynar ("Nowina") to go to some village with several men from the squadron led by "Mścisław" in order to eliminate one of its residents [an informant of the UB; the officer executed the order by the end of the month, and filed a report in Rudy]. ${ }^{142}$

Szendzielarz's partisans ambushed a truck carrying a 20-strong group of Union of Rural Youth (Związek Młodzieży Wiejskiej, ZMW) activists, who were travelling from Hajnówka to Białowieża. The group

stepped down from the vehicle, and "Lupaszka" talked to each one of them, urging them to leave the Z.W.M [sic! ZMW]. He then ordered to strip everyone down to just their underwear, after which they were beaten by "Jurand". The only one spared was the brother of "Pędzelek" (I do not remember his name), whose escape was staged and even shots were fired after him in vain. As far as I know, he was not beaten at all, as he was the one who informed "Eupaszka" (by intermediary of "Pędzelek") about the ZWM [sic! ZMW] transport to Hajnówka. Once it was all over, "Lupaszka” ordered the undressed girls and boys from the ZWM [sic! ZMW] to march to Hajnówka, $10 \mathrm{~km}$ away from the ambush site. The vehicle, emptied of all food, was then sent away by Łupaszka after some time to follow the unlucky ZWM [sic! ZMW] members. ${ }^{143}$

These were the last events of Lvova's service in Szendzielarz's unit during WWII, although she continued to assist his successive units after the war as well:

I was very in love with the commander. One day, "Łupaszka" - a lieutenant back then invited me to his quarters, and, in the presence of an adjutant as witness, he announced that, from that day, he and I were engaged. He explained that he was officially separated

142 AIPN BU, 0,259/436, file 10, Stenogram z 4, 5, 6 dnia rozprawy p-ko Olechowiczowi Antoniemu i innym, rok 1950, fol. 38.

${ }^{143}$ Ibid., fols. 38-40. 
from his wife, that he was no longer involved. But I did not become "Mrs. Commander" for that matter. I did not aggrandise myself. Nothing has changed. I remained the medical orderly, and I would still address Zygmunt as commander; we have had no civil nor church wedding. ${ }^{144}$

After many unsuccessful attempts to legalise their existence and settle down, Szendzielarz and Lvova have been arrested by the UB on 30 June 1948. Lvova was brought before a military court on 23 October 1950, alongside Lt.-Col. Antoni Olechnowicz, Capt. Henryk Borowski, MSgt. Lucjan Minkiewicz, and the latter's wife Wanda. The judge sentenced the men to death, pregnant Wanda Minkiewicz to 12 years in prison, and Lidiya Lvova to life imprisonment. She was released in 1956 by virtue of amnesty. After graduating from the Institute of Archaeology at the University of Warsaw, she got married, and adopted a double surname: Lidia Lwow-Eberle. She would later work at the Museum of Warsaw (now the Historical Museum of the Capital City of Warsaw), head the archaeological department of the Archaeological Commission of the Civic Committee for the Reconstruction of the Royal Castle, and participate in the reconstruction herself. She retired in 1984. After the collapse of communism in Poland, she became active within veteran organisations of the Home Army. She participated in the determination of the circumstances of Zygmunt Szendzielarz's death and place of his secret burial, and now promotes the history of the Home Army and the $5^{\text {th }}$ Brigade AK, while maintaining an active anti-communist stance. All while being a Polish patriot, she cultivates relations with her Motherland - Russia; she has visited Saint Petersburg as recently as in June 2015 . $^{145}$

The Russian immigrants mentioned in the present article constitute examples of unconventional behaviour. Most history enthusiasts claim that in World War II, the White Russians were involved on the German side, against the Bolsheviks. Archival inquiries and live interactions with surviving witnesses of history unveiled some little-known events. This article marks only the beginning of a wider research on the fate of numerous Russian immigrants (White, anti-communist) involved in the struggle against National-Socialist Germany; one should also mention Aleksandr Grigorovich, Konstantin Ivanov from the Garwolin AK district (who died in exile at the Borovichi hospital), Jan Szaliłow ("Renek”), Dmitri Sokoltsov,

144 Testimony of Lidia Lwow-Eberle, March 2015, Author's archive.

145 AIPN BU, 0 259/436, vol. 4, Postanowienie o pociągnięciu do odpowiedzialności karnej Lidii Lwow, fol. 67; AIPN BU, 0 259/436/17, vol. 9, Departament III M.B.P., Wydział 1, nr 3520/B/48, zał. 2 Protokół przesłuchania [...] w charakterze podejrzanego Lwow Lidia ps. "Ewa”, 27.08.1948 [Dept. III of MBP, Sect. I; Report of interrogation of suspect Lidiya Lvova], fols. 35-37; Krajewski, Na straconych posterunkach, p. 803; and Motyka, Na białych Polaków obława, pp. 252254 
Irena Tamara Mishtal (Tamara Pyetukhova), and many others. They have actively engaged in resistance and fought as if against all tendencies, against the easier life - and often risking theirs. This fascinating and unknown episode of World War II requires a deeper systematisation and the verification of numerous biographies of the representatives of the pre-war post-revolutionary Russian diaspora living in the Second Polish Republic, who have spent the war fighting "for our freedom and yours".

\section{Russian Emigrants and Polish Underground in 1939-1948 Abstract}

The present article brings up a practically forgotten episode in the history of Russian emigration. An archival inquiry revealed the engagement of several Russian post-revolutionary émigrés in the fight against the Germans during World War II in the territory of occupied Poland. The persons described in this concise article are an example of unconventional behaviour. One year ago, the author of the present article, when asked on which side Russian émigrés had fought in World War II, answered: on the German side, against the Bolsheviks. However, numerous discourses with experts and the reading of several books on this subject changed his opinion; and the contact with a living eyewitness of history, who remembers the events described in the article, proved to be priceless.

The article is devoted to the fate of Russian anti-communist émigrés, called "Whites", engaged in the fight against the National Socialist Germans and Austrians. Several glorious examples are mentioned here, such as the forgotten Tumanow brothers (unknown even to the Warsaw Uprising Museum), Jurasow, Kurochkin, or Tryfonow, who all fought in the Polish Home Army of the Navahrudak (Nowogródek) and Wilno/Vilno areas. The article is not exhaustive, as some other figures should be mentioned as well, namely Aleksandr Grigorovich, Jan Szaliłow ("Renek"), Dmitri Sokoltsov, or Irena Tamara Misztal (Tamara Pyetukhova). They have actively engaged in resistance, and fought as if against all tendencies, against the easier life - and often risking theirs. This fascinating and unknown episode of World War II requires a deeper systematisation and the verification of numerous biographies of the representatives of the pre-war post-revolutionary Russian diaspora living in the Second Polish Republic, who spent the war fighting "for our freedom and yours".

\section{Русские эмигранты и польское подполье в 1939-1947 гг. Аннотация}

Статья затрагивает почти забытый эпизод истории российской эмиграции. Архивные запросы позволили идентифицировать проблему вовлечения послереволюционных российских эмигрантов в борьбу с немцами во время Второй мировой войны на оккупированных польских территориях. Люди, упомянутые в этой короткой статье, являются примером нешаблонного поведения. Пишущий эти слова, еще два года назад на вопрос, на которой стороне находились русские эмигранты во время Второй мировой войны - отвечал: на немецкой - против большевиков. Первые известия пришли вместе с беседами со специалистами и предложенными материалами для чтения, а бесценным стало знакомство со свидетелем истории - женщиной, помнящей и видевшей собственными глазами описанные здесь происшествия. 
Эта статья напоминает о судьбах антикоммунистических российских эмигрантов т. н. “белых", вовлеченных в борьбу против национал-социалистических немцев и австрийцев. Это достойные похвалы примеры, как совсем забыты братья Тумановы (о которых не знал никто, даже персонал Исторического отдела Музея Варшавского восстания), или Юрасов, Курочки и Трифонов, сражавшиеся в рядах Новогрудской и Виленской Армии Краевой. Статья не исчерпывает сюжета, так как надо бы упомянуть и Александра Григоровича, Яна Шалилова псевдоним “Ренек”, Дмитрия Сокольцова или Ирену Тамару Мишталь (Тамару Пиотух), а также других. Они вели подпольную деятельность и сражались как будто бы против течения, против более легкой жизни, а даже рискуя ею.

Этот захватывающий и неизвестный эпизод военной истории нуждается в более глубокой систематизации и проверке многих биографий представителей довоенной послереволюционной российской диаспоры, проживавшей во Второй Речи Посполитой и сражавшейся во время войны “за свободу - нашу и вашу”.

Перевод Агнешка Поспишил

\section{Bibliography}

\section{Archival material}

Central Archives of Modern Records (Archiwum Akt Nowych)

AK, 203/VII-4, 202/II-17, 228/8-2

MSZ, Ambasada RP w Paryżu, file 82

Mikrofilm aleksandryjski T-311, roll 213

Archive of Historical Documentation of the Polish People's Republic (Archiwum Dokumentacji

Historycznej $P R L)$

$\mathrm{N}-\mathrm{I} / 29$

Archive of the Institute of National Remembrance (Archiwum Instytutu Pamięci Narodowej)

BU 01222/3114; 00168/79, vol. 8; 185/340, vol. 1; 0-423/2603; $001121 / 4399 ; 1820 / 2$;

0 259/436, vol. 1, vol. 4, vol. 10; 0 259/436/17, vol. 2, vol. 9

GK 919/2656

Archive at the Warsaw Rising Museum (Archiwum Muzeum Powstania Warszawskiego)

$\mathrm{V} / 73, \mathrm{P} / 5187$

Central Military Archive (Centralne Archiwum Wojskowe)

IX.3.26.3

Central Archive of the Ministry of Defense of the Russian Federation (Центральный архив Министерства обороны Российской Федерации)

f. 233 , o. 2380 , d. 23

Author's archive - testimonies: Stanisław Aronson, Józef Bandzo, Lidia Lwow-Eberle

\section{Published sources}

Armia Krajowa $w$ dokumentach 1939-1945, vol. 1, part 2: Wrzesień 1939 - czerwiec 1941, eds. Andrzej Suchcitz, Waldemar Grabowski et al., Warszawa, 2015.

Armia Krajowa $w$ dokumentach 1939-1945, vol. 3: Kwiecień 1943-Lipiec 1944, London, 1976. Nowogródzki Okręg AK w dokumentach, ed. K. Krajewski, Warszawa, 2009.

Obrona Warszawy w 1939 r. Wybór dokumentów wojskowych, comp. M. Cieplewicz, Warszawa, 1968. 
Rozkazy dzienne Brygady Świętokrzyskiej Narodowych Sił Zbrojnych 1944-1945, comp. C. Brzoza, Kraków, 2003.

Генерал Власов. История предательства, vol. 1: Нацистский проект "Aktion Wlassow", еd. А.Н. Артизов, Москва, 2015.

\section{Memoirs and diaries}

Bohun-Dąbrowski A., Byłem dowódca Brygady Świętokrzyskiej NSZ. Pamiętnik dowódcy, świadectwa żolnierzy, dokumenty, Warszawa, 1989.

Bonarowski E. “Ostromir”, Burza nad Dworcem Gdańskim. W bój bez broni, Warszawa-Kraków, 2014.

Christa O., U "Szczerbca” $i$ "Łupaszki”, Warszawa, 2000.

Drucka N., Trzy czwarte... Wspomnienia, Łomianki, 2011.

Iwaszkiewiczowa A., Dzienniki i wspomnienia, Warszawa, 2000.

Korboński S., W imieniu Rzeczypospolitej, Warszawa, 2009.

Korejwo M., Moje ścieżki partyzanckie. W 3. Wileńskiej Brygadzie Armii Krajowej "Szczerbca", Warszawa-Kraków, 2014.

Leski K., Życie niewłaściwie urozmaicone. Wspomnienia oficera wywiadu i kontrwywiadu AK, vol. 1, Gdańsk, 2009.

Nałkowska Z., Dzienniki, vol. 3: 1918-1929, Warszawa, 1980.

Skirgieło A., Zapiski ze stuletniego życia, Warszawa, 2006.

Wat A., Mój wiek. Pamiętnik mówiony, vol. 1, Warszawa, 1990.

\section{Other sources}

Amtliches Fernsprechbuch für den Distrikt Warschau 1942, Warschau, 1942.

Drugi Powszechny Spis Ludności z dn. 9.XII 1931 r., Miasto Wilno, Statystyka Polski, Series C, vol. 48, Warszawa, 1937.

Drugi Powszechny Spis Ludności z dn. 9 XII 1931 r., Województwo Nowogródzkie, Statystyka Polski, Series C, vol. 71, Warszawa, 1938.

Drugi Powszechny Spis Ludności z dn. 9 XII 1931 r., Województwo Wileńskie bez miasta Wilna, Statystyka Polski, Series C, vol. 36, Warszawa, 1936.

Konspiracja i opór społeczny w Polsce 1944-1956. Słownik Biograficzny, vol. 2, ed. T. Balbus et al., Kraków-Warszawa-Wrocław, 2004.

Mały rocznik statystyczny 1939, Warszawa, 1938.

Motyl M., Rutkowski S., Rejestr miejsc i faktów zbrodni popetnionych przez okupanta hitlerowskiego. Powstanie Warszawskie 1 VIII - 2 X 1944, Warszawa, 1994.

Posłowie i senatorowie Rzeczypospolitej Polskiej 1919-1939. Słownik biograficzny, vol. 3: K-Ł, eds. P. Majewski, G. Mazur, Warszawa, 2005.

Spis abonentów sieci telefonicznej m.st. Warszawy P.A.S.T. i warszawskiej sieci okręg P.P.T.T. Rok 1939/40, Warszawa, 1939.

Stanisławski W., "Myśl polityczna emigracji rosyjskiej w II Rzeczpospolitej: interpretacje przeszłości i koncepcje polityczne", PhD dissertation under supervision of Prof. dr hab. S. Rudnicki, Institute of History, University of Warsaw, 2002, archival number: P. Dr. 358.

Telefonverzeichnis der stadt Warschau, Warszawa, 1940.

Współcześni polscy pisarze i badacze literatury. Słownik bibliograficzny, vol. 2, eds. J. Czachowska and A. Szałagan, Warszawa, 1994, pp. 209-211. 
История отечественной коллаборации. Материаль и исследования, Москва, 2017.

От Зарубежья до Москвы. Национально-Трудовой Союз (НТС) в воспоминаниях и документах 1924-2014, ed. В. Сендеров, Москва, 2014.

\section{Secondary literature}

Aronson S., Bukalska P., Rysiek z Kedywu. Niezwykłe losy Stanisława Aronsona, Kraków, 2009. Banasikowski E., Na zew Ziemi Wileńskiej, Warszawa-Paryż, 1990.

Bechta M., Muszyński W.J., Przeciwko Pax Sovietica. Narodowe Zjednoczenie Wojskowe i struktury polityczne ruchu narodowego wobec reżimu komunistycznego 1944-1956, Warszawa, 2017.

Bohdanowicz J., 3. Brygada Szczerbca Armia Krajowa Okręg Wileński, Warszawa, 2008.

Bolecki W., Ptasznik z Wilna. O Józefie Mackiewiczu. Zarys monograficzny, Kraków, 2013.

Boradyn Z., Niemen rzeka niezgody. Polsko-sowiecka wojna partyzancka na Nowogródczyźnie 1943-1944, Warszawa, 2013.

Cabanowski M., Generał Stanisław Bulak-Balakhovich. Ostatni Kmicic II RP i wyklęci żołnierze wojny polsko-sowieckiej 1920 r., Warszawa-Kraków, 2013.

Die polnische Heimatarmee. Geschichte und Mythos der Armia Krajowa seit dem Zweiten Weltkrieg, eds. B. Chiari, J. Kochanowski, München [Munich], 2003.

Drucka N., Szkoła $w$ podziemiu. Z dziejów polskiego tajnego nauczania w latach okupacji hitlerowskiej, Warszawa, 1973.

Grabowski W., Polska Tajna Administracja Cywilna 1940-1945, Warszawa, 2003.

Jastrzębski A., "Życie na krawędzi”, in: Życie na krawędzi. Wspomnienia żołnierzy antyhitlerowskiego wywiadu, comp. W. Kozaczuk, Warszawa, 1980.

Juzwenko A., Polska a "biała" Rosja (od listopada 1918 do kwietnia 1920 r.), Wrocław, 1973.

Komorowski K., Polityka i walka. Konspiracja zbrojna ruchu narodowego 1939-1945, Warszawa, 2000.

Korab-Żebryk R., Biała Księga - W obronie Armii Krajowej na Wileńszczyźnie, Lublin, 1991.

Korab-Żebryk R., Operacja Wileńska AK, Warszawa, 1988.

Krajewski K., Łabuszewski T., "Łupaszka”, "Młot”, "Huzar”. Działalność 5 i 6 Brygady Wileńskiej AK 1944-1952, Warszawa, 2002.

Krajewski K., Łabuszewski T., Białostocki Okręg AK-AKO. VII 1944 - VIII 1945, Warszawa, 1997.

Krajewski K., Na straconych posterunkach. Armia Krajowa na Kresach Wschodnich II Rzeczypospolitej 1939-1945, Kraków, 2015.

Krajewski K., Uderzeniowe Bataliony Kadrowe 1942-1944, Warszawa, 1993.

Kułak J., Rozstrzelany oddział. Monografia 3 Wileńskiej Brygady NZW Białostocczyzna 19451946, Białystok, 2007.

Literatura rosyjska na emigracji. Współcześni pisarze rosyjscy w Polsce. Frazeologia i frazeografia. Materiały konferencji naukowej (9-10 listopada 1995 r.), eds. W. Skrunda, W. Zmarzer, Warszawa, 1996.

Mitzner P., Warszawski krąg Dymitra Fiłosofowa, Warszawa, 2015.

Motyka G., Na białych Polaków obława. Wojska NKWD w walce z polskim podziemiem 19441953, Kraków, 2014

Muszyński W.J., Duch młodych. Organizacja Polska i Obóz Narodowo-Radykalny w latach 1934-1944. Od studenckiej rewolty do konspiracji niepodległościowej, Warszawa, 2011.

Niwiński P., Okręg Wileński AK w latach 1944-1948, Warszawa-Kraków, 2014.

Piekarski M., Samotna placówka, Warszawa, 1989.

Rostkowski J., Świat Muszkieterów. Zapomnij albo zgiń, Poznań, 2016.

Skirgiełło A., Powstanie i rozwój Zakładu Systematyki i Geografii Roślin Uniwersytetu Warszawskiego (w zarysie), Warszawa, 2001. 
Spałek R., Komuniści przeciwko komunistom. Poszukiwanie wroga wewnętrznego w kierownictwie partii komunistycznej w Polsce w latach 1948-1956, Poznań-Warszawa, 2014.

Thomas N., Caballero C., Germany's Eastern Front Allies (2): Baltic Forces, Oxford, 2012.

Tomaszewski L., Wileńszczyzna lat wojny i okupacji 1939-1945, Warszawa, 2010.

Urbanek B., Pielegniarki i sanitariuszki w Powstaniu Warszawskim w 1944 r., Warszawa, 1988.

Warszawa we wrześniu 1939 r. Obrona i życie codzienne, ed. C. Grzelak, Warszawa, 2004.

Wieczorkiewicz P.P., Historia polityczna Polski 1935-1945, Poznań, 2014.

Wołkonowski J., Okręg Wileński Związku Walki Zbrojnej Armii Krajowej w latach 1939-1945, Warszawa, 1996.

Wroniszewski J.K., Ochota - Okęcie. Przewodnik historyczny po miejscach walk i pamięci z lat 1939-1944, Warszawa, 2002 (series: Warszawskie Termopile 1944).

Zimmerman J.D., The Polish Underground and the Jews, 1939-1945, Cambridge-New York, 2015.

Булгаков В., Словарь русских зарубежных писателей, New York, 1993.

Гомолицкий Л., Сочинения русского периода. В 3 m., vol. 2: Стихотворения и переводьь. Роман в стихах. Из переписки Серебряный век. Паралипоменон, еd. Л. Флейшман, Москва, 2011.

Грибков И., Ковтун И., Жуков Д., Особый штаб “Россия”, Москва, 2011.

Жуков Д., Ковтун И., 29-я гренадерская дивизия СС “Каминский”, Москва, 2009.

Зарубежная Россия 1917-1939 г2.: Сборник статей, ed. В.Ю. Черняев, Санкт-Петербург, 2000.

Лавринец П., “К истории Виленского содружества поэтов”, Literatura, 2002, no. 44.

Окулов А., В борьбе за Белую Россию. Холодная гражданская война, Москва, 2013.

Русская эмиграция в борьбе с большевизмом, еd. С.В. Волков, Москва, 2005.

\section{Press}

Acta Societatis Botanicorum Poloniae

Biuletyn Instytutu Pamięci Narodowej

Dzieje Najnowsze

Echa Polesia

Glaukopis

Journal of Slavic Military Studies

Rocznik Historii Czasopiśmiennictwa Polskiego

Rocznik Mazowiecki

Rocznik Warszawski

Studia Religiologica

Zagłada Żydów Studia i Materiały

Ежегодник Дома русского зарубенья

Новая Польша

Новый журнал

\section{Internet sites}

http://www.cmentarzekomunalne.com.pl

http://www.dziennik.com/

http://forum.vgd.ru 
http://www.gazetawilanowska.pl

http://www.istpravda.ru

https://www.forces-war-records.co.uk

http://www.1944.pl

Hubert Kuberski, MA, graduate of the Institute of History of the University of Warsaw; historian, journalist, and filmmaker; his interests focus on: the Balkans, World War II, "Bandenbekämpfung", East European Judaica and Russian émigrés. Author of a publication: Sojusznicy Hitlera 1941-45. Armie sojusznicze Niemiec na froncie wschodnim i na Bałkanach (Warszawa, 1993); and a study "Wschodnioeuropejscy ochotnicy cudzoziemscy w niemieckich oddziałach Ostheer, SS i policji, pacyfikujących Powstanie Warszawskie. Casus 'własowców', Kałmuków i SS Galizien”, Dzieje Najnowsze, 2015, no. 3 (h.kuberski@gmail.com). 